VILNIUS GEDIMINAS TECHNICAL UNIVERSITY

Adas MEŠKĖNAS

\title{
SERVICEABILITY ANALYSIS OF STEEL FIBRE REINFORCED CONCRETE BEAMS
}

DOCTORAL DISSERTATION

TECHNOLOGICAL SCIENCES,

CIVIL ENGINEERING (02T)

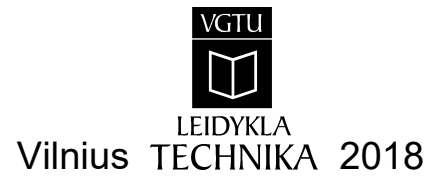


Doctoral dissertation was prepared at Vilnius Gediminas Technical University in 2011-2018.

The dissertation is defended as an external work.

\section{Scientific Consultant}

Assoc. Prof. Dr Darius BAČINSKAS (Vilnius Gediminas Technical University, Civil Engineering - 02T).

The Dissertation Defence Council of Scientific Field of Civil Engineering of Vilnius Gediminas Technical University:

\section{Chairman}

Prof. Dr Juozas VALIVONIS (Vilnius Gediminas Technical University, Civil Engineering - 02T).

\section{Members:}

Assoc. Prof. Dr Habil. Renata KOTYNIA (Lodz University of Technology, Poland, Civil Engineering - 02T),

Assoc. Prof. Dr Vladimir POPOV (Vilnius Gediminas Technical University, Civil Engineering - 02T),

Dr Rimvydas STONYS (Vilnius Gediminas Technical University, Materials Engineering - 08T),

Assoc. Prof. Dr Vitoldas VAITKEVIČIUS (Kaunas University of Technology, Civil Engineering - 02T).

The dissertation will be defended at the public meeting of the Dissertation Defence Council of Civil Engineering in the Senate Hall of Vilnius Gediminas Technical University at 10 a. m. on 27 February 2018.

Address: Saulètekio al. 11, LT-10223 Vilnius, Lithuania.

Tel.: +370 5274 4956; fax +370 5270 0112; e-mail: doktor@vgtu.lt

A notification on the intend defending of the dissertation was send on 26 January 2018.

A copy of the doctoral dissertation is available for review at VGTU repository http://dspace.vgtu.lt and at the Library of Vilnius Gediminas Technical University (Saulètekio al. 14, LT-10223 Vilnius, Lithuania).

VGTU leidyklos TECHNIKA 2018-004-M mokslo literatūros knyga

ISBN 978-609-476-092-1

(C) VGTU leidykla TECHNIKA, 2018

(C) Adas Meškènas, 2018

adas.meskenas@vgtu.lt 
VILNIAUS GEDIMINO TECHNIKOS UNIVERSITETAS

Adas MEŠKĖNAS

\section{PLIENO PLAUŠU ARMUOTŲ GELŽBETONINIŲ SIJŲ TINKAMUMO RIBINIO BŪVIO ANALIZE்}

DAKTARO DISERTACIJA

TECHNOLOGIJOS MOKSLAI, STATYBOS INŽINERIJA (02T) 
Disertacija rengta 2011-2018 metais Vilniaus Gedimino technikos universitete.

Disertacija ginama eksternu.

\section{Mokslinis konsultantas}

doc. dr. Darius BAČINSKAS (Vilniaus Gedimino technikos universitetas, statybos inžinerija - 02T).

Vilniaus Gedimino technikos universiteto Statybos inžinerijos mokslo krypties disertacijos gynimo taryba:

\section{Pirmininkas}

prof. dr. Juozas VALIVONIS (Vilniaus Gedimino technikos universitetas, statybos inžinerija - 02T).

\section{Nariai:}

doc. habil. dr. Renata KOTYNIA (Lodzès technologijos universitetas, Lenkija, statybos inžinerija-02T),

doc. dr. Vladimir POPOV (Vilniaus Gedimino technikos universitetas, statybos inžinerija - 02T),

dr. Rimvydas STONYS (Vilniaus Gedimino technikos universitetas, medžiagų inžinerija - 08T),

doc. dr. Vitoldas VAITKEVIČIUS (Kauno technologijos universitetas, statybos inžinerija - 02T).

Disertacija bus ginama viešame Statybos inžinerijos mokslo krypties disertacijos gynimo tarybos posedyje 2018 m. vasario 27 d. 10 val. Vilniaus Gedimino technikos universiteto senato posėdžių salejje.

Adresas: Saulètekio al. 11, LT-10223 Vilnius, Lietuva.

Tel.: (8 5) 274 4956; faksas (8 5) 270 0112; el. paštas doktor@vgtu.lt

Pranešimai apie numatomą ginti disertaciją išsiųsti $2018 \mathrm{~m}$. sausio $26 \mathrm{~d}$.

Disertaciją galima peržiūrèti VGTU talpykloje http://dspace.vgtu.lt ir Vilniaus Gedimino technikos universiteto bibliotekoje (Sauletekio al. 14, LT-10223 Vilnius, Lietuva). 


\section{Abstract}

In last decades, the use of steel fibre reinforced concrete (SFRC) as a construction material has developed beyond the traditional applications. Despite the notable research advances in the fibre reinforcement technology and the development of guidelines and recommendations for structural design, questions continue to arise regarding the characterization and modelling of SFRC. The definition of the constitutive models of SFRC and the development of methods for the prediction of deformation and cracking of SFRC structural elements either without or with a traditional bar reinforcement have been extensively studied by many researchers, though their adequacy for certain applications still remains an issue. These subjects require further research in order to work towards an accurate and efficient design procedure.

This thesis investigates the deformation and cracking behaviour of SFRC beams with and without steel bars. Special attention is paid for the analysis of residual strength of tensile SFRC - the fundamental material characteristic for analysis of SFRC structures. With the aim of identifying the residual strength responses, an extensive experimental investigation of 48 flexural SFRC elements subjected to three- and four-point loading is executed. A simple technique for prediction of residual strength from standard three-point bending test is proposed. The main advantage of the proposed technique (in comparison with the standard methods) is its capability to calculate residual strength of tensile SFRC at any given loading or deflection.

For prediction of deformation and cracking behaviour of SFRC beams with bar reinforcement a numerical simulation algorithm is developed. Unlike the most of the serviceability techniques that are used specifically either for deformation or crack analysis, the algorithm based on the stress-transfer approach allows to simultaneously model both the deflection and cracking response of SFRC beams with bar reinforcement. In addition to the residual strength, the laws characterising bond-slip and damage zone are the basic constitutive parameters governing the results of analysis. Being mechanically sound, the developed technique can be universally applied to any type of concrete (plain, high strength/performance) and reinforcement (steel, fibre reinforced polymer). To evaluate the adequacy of the developed technique, an experimental program consisting of 11 full scale reinforced concrete beams with varying fibre content was performed. Comparison of numerical and experimental results proved the applicability of the proposed modelling method.

The author have published 14 articles on the topic of the dissertation ( 5 of them in the journals with an Impact Factor and 3 in the conference proceedings referred by the Clarivate Analytics Web of Science database). 


\section{Reziumè}

Pastaraisiais dešimtmečiais plieno plaušu armuotas betonas vis plačiau taikomas sudètingose statinių konstrukcijose. Nepaisant atliktų reikšmingų mokslinių tyrimų bei vystomų projektavimo rekomendacijų, dispersiškai armuoto betono savybių nustatymas ir modeliavimas vis dar yra pakankamai sudètingas uždavinys. Standartiškai nustatytų plieno plaušu armuoto tempiamojo betono medžiagų modelių taikymas yra tinkamas dispersiškai armuotų konstrukcijų analizei, tačiau dažnai lemia dideles paklaidas betono konstrukcijų su strypine armatūra deformacijų ir pleišèjimo nustatymui. Tinkamas medžiagų modelių parinkimas, apimantis dispersiškai armuoto betono liekamuosius įtempius bei armatūros ir betono sąveiką, turi lemiamos įtakos, analizuojant konstrukcijų tinkamumo ribinį būvị.

Disertaciniame darbe atliekama statine trumpalaike apkrova veikiamų, plieno plaušu armuotų betoninių ir gelžbetoninių elementų deformacijų bei pleišejimo analizè. Plieno plaušu armuoto tempiamojo betono liekamojo stiprio nustatymui atlikta eksperimentinè programa, kurią sudare 48 standartinio dydžio lenkiamieji elementai, apkrauti viena arba dviem koncentruotomis apkrovomis. Darbe pasiūlytas dispersiškai armuoto betono liekamujų itempių nustatymo metodas, kuris, taikant eksperimentinius standartinio dydžio dispersiškai armuotų betoninių elementų duomenis, leidžia nustatyti liekamajị stiprį bet kuriuo apkrovos veikimo momentu. Pasiūlytas metodas gali būti universaliai taikomas ịvairaus dydžio ir geometrijos bandiniams.

Disertacijoje pasiūlytas plieno plaušu ir strypais armuotų gelžbetoninių elementų deformacijų ir pleišejimo modeliavimo metodas, paremtas ịtempių perdavimo (diskretaus pleišèjimo) koncepcija. Skirtingai nuo daugelio tinkamumo ribinio būvio analizès algoritmų, šiuo metodu galima adekvačiai modeliuoti konstrukcijų deformacijas bei plyšių vystymąsi, ịvertinant dispersiškai armuoto betono liekamajji stiprị, strypinès armatūros ir betono sukibimo bei pažeidimo zonos reiškinius. Pasiūlytas ịtempių perdavimo algoritmas gali būti universaliai taikomas ịvairių rūšių betonų (ịprastam, didelio stiprio) ir skirtingų tipų plaušo ir strypinès armatūros (plieno, kompozitinès) analizei. İvertinti modeliavimo rezultatų adekvatumui atlikti 11 realaus dydžio skirtingu plieno plaušo ir strypinės armatūros kiekiu armuotų gelžbetoninių elementų eksperimentiniai tyrimai. Gautų skaitinių ir eksperimentinių rezultatų analizė patvirtino siūlomo metodo tinkamumą plieno plaušu armuotų sijų tinkamumo ribinio būvio analizei.

Autorius disertacijos tema paskelbė 14 mokslinių publikacijų, iš kurių 5 žurnaluose turinčiuose cituojamumo rodiklị ir 3 - konferencijų rinkiniuose, referuojamuose Clarivate Analytics Web of Science duomenų bazeje. 


\section{Symbols}
$A_{c} \quad-\quad$ is the area of plain concrete net section;
$A_{s 1} \quad-\quad$ is the area of tensile reinforcement;
$A_{s 2} \quad-\quad$ is the area of compressive reinforcement;
$E_{c} \quad-\quad$ is the modulus of elasticity of concrete;
$E_{c m} \quad-\quad$ is the average modulus of elasticity of concrete;
$F \quad-\quad$ is the internal force;
$I_{c r} \quad-\quad$ is the moment of inertia for the fully cracked section;
$I_{e l} \quad-\quad$ is the moment of inertia for uncracked concrete section;
$L \quad \quad \quad-\quad$ is the length of the element;
$M \quad-\quad$ is the bending moment;
$M_{c r} \quad-\quad$ is the cracking moment;
$M_{u}, M_{u l t} \quad-\quad$ is the ultimate bending moment;
$N \quad-\quad$ is the axial force;
$P \quad-\quad$ is the load;
$P_{c r} \quad-\quad$ is the cracking load;
$S_{r, \max } \quad-\quad$ is the maximum crack spacing;
$V_{f} \quad-\quad$ is the steel fibre volume percentage;
$W \quad-\quad$ is the section modulus;
$a_{2} \quad-\quad$ is the cover depth of the compressive reinforcement; 
$b \quad-\quad$ is the width of the section;

$d \quad-\quad$ is the effective depth of a section or diameter of reinforcement;

$d_{f} \quad-\quad$ is the diameter of fibre;

$f_{c} \quad-\quad$ is the cylinder compressive concrete strength;

$f_{c m} \quad-\quad$ mean value of concrete compressive strength at an age of 28 days;

$f_{c t} \quad-\quad$ is the tensile concrete strength;

$f_{c t m, f l} \quad-$ is the mean flexural tensile strength of FRC;

$f_{f b r} \quad-\quad$ is the residual strength of FRC;

$f_{R}, f_{r} \quad-\quad$ is the modulus of rupture;

$f_{y} \quad-\quad$ is the yield strength;

$h \quad-\quad$ is the height of a section;

$h_{s p} \quad-\quad$ is the depth of the notched section;

$i \quad-\quad$ is the load increment;

$l_{c r} \quad-\quad$ is the crack spacing;

$l_{d} \quad-\quad$ is the length of the damage zone;

$l_{f} \quad-\quad$ is the length of fibre;

$l_{t r} \quad-\quad$ is the stress transfer length;

$n \quad-\quad$ is the number of test points in the statistical analysis;

$p \quad-\quad$ is the reinforcement ratio;

$\mathrm{s} \quad-\quad$ is the reinforcement slip;

$S_{\mathrm{rm}} \quad-\quad$ is the average crack spacing;

w $\quad-\quad$ is the crack width;

$y_{c} \quad-\quad$ is the coordinate of centroid of plain concrete net section;

$\delta \quad-\quad$ is the mid-span deflection;

$\varepsilon_{c} \quad-\quad$ is the strain of compressive concrete;

$\varepsilon_{c l} \quad-\quad$ is the maximum compressive strain of concrete;

$\varepsilon_{c m} \quad-\quad$ is the mean strain of compressive concrete;

$\varepsilon_{c r}, \varepsilon_{s, c r} \quad-\quad$ is the tensile strain capacity;

$\varepsilon_{s} \quad-\quad$ is the strain of steel;

$\Delta \varepsilon_{s} \quad-\quad$ is the steel strain increment;

$\varepsilon_{t}, \varepsilon_{c t} \quad-\quad$ is the strain of tensile concrete;

$\varepsilon_{s m} \quad-\quad$ is the mean strain of steel;

$\varepsilon_{u} \quad-\quad$ is the ultimate strain of compressive concrete;

$\kappa \quad-\quad$ is the curvature;

$\sigma_{c} \quad-\quad$ is the compressive concrete strength;

$\sigma_{c t} \quad-\quad$ is the stress of tensile concrete;

$\sigma_{f r} \quad-\quad$ is the residual stress of FRC;

$\sigma_{\mathrm{s}}, \sigma_{\mathrm{sr}} \quad-\quad$ is the stress of steel;

$\sigma_{\mathrm{sy}} \quad-\quad$ is the yielding stress;

$\tau \quad-\quad$ is the bond stress between concrete and a fibre or bar reinforcement;

$\varnothing \quad-\quad$ is the diameter of a reinforcement bar. 


\section{Abbreviations}

CMOD - crack mouth opening displacement;

CTOD - crack tip opening displacement;

$\mathrm{FE} \quad-$ finite element;

FRC - fibre reinforced concrete;

LVDT - linear voltage displacement transducer;

NSC $\quad-$ normal strength concrete;

$\mathrm{RC} \quad-$ reinforced concrete;

$\mathrm{RH} \quad-$ relative humidity;

SFRC $\quad-\quad$ steel fibre reinforced concrete. 



\section{Contents}

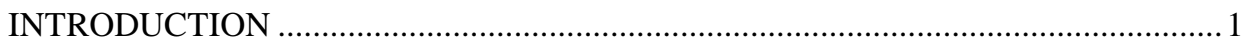

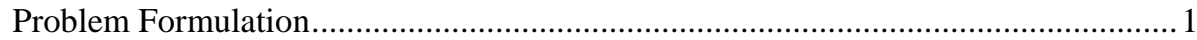

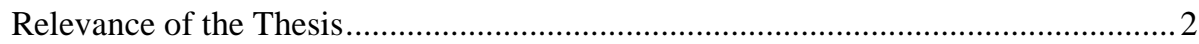

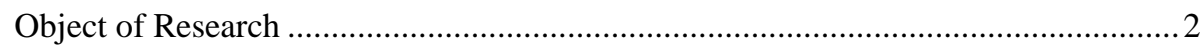

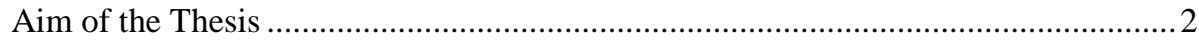

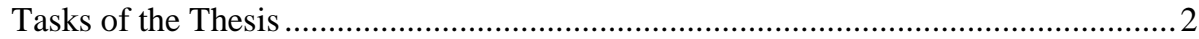

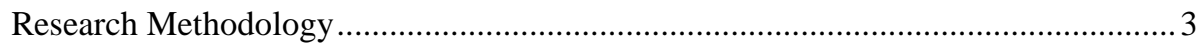

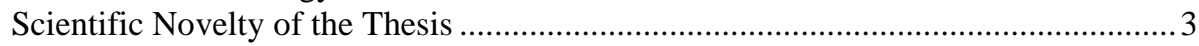

Practical Significance of Achieved Results .............................................................. 3

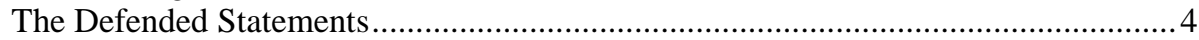

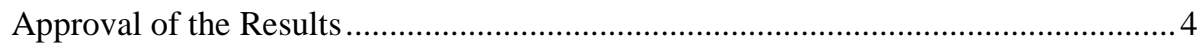

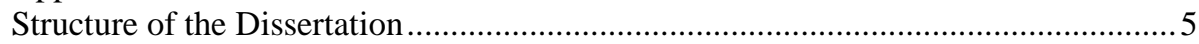

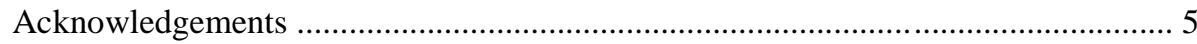

1. CHARACTERIZATION AND MODELLING OF STEEL FIBRE

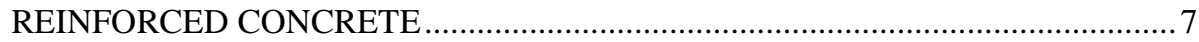

1.1. Fibre Reinforced Concrete for Structural Applications ........................................ 8

1.1.1. Development and Application ........................................................... 8

1.1.2. Technology of Fibre Concrete ……………...........................................

1.2. Material Properties of Steel Fibre Reinforced Concrete ...................................... 13

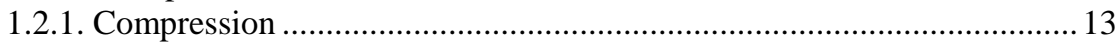

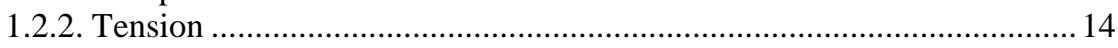

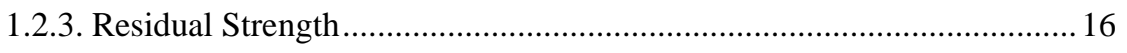


1.3. Constitutive Modelling of Steel Fibre Reinforced Concrete in Tension ............ 18

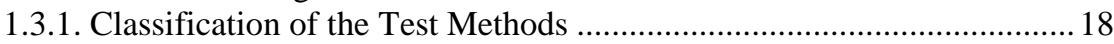

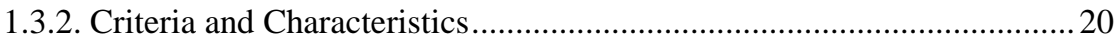

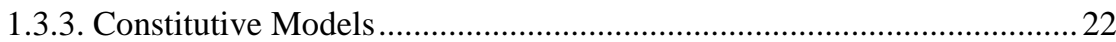

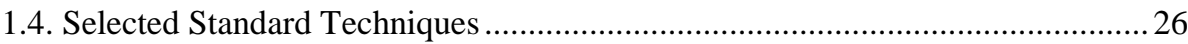

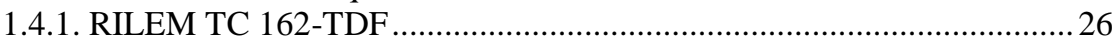

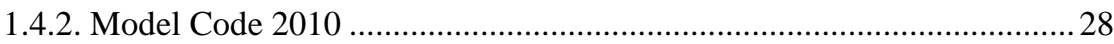

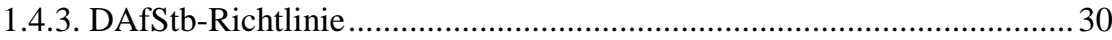

1.5. Modelling of Steel Fibre Reinforced Concrete Beams with Bar

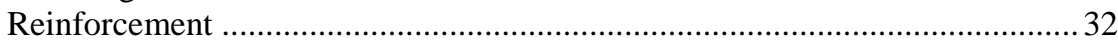

1.6. Conclusions of Chapter 1 and Formulation of the Tasks of the Thesis ............... 34

2. ANALYSIS OF RESIDUAL STRENGTH OF STEEL FIBRE REINFORCED

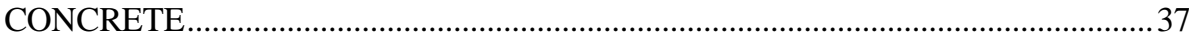

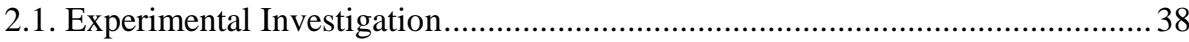

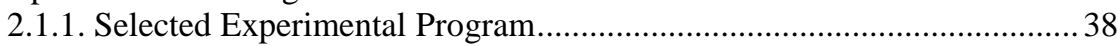

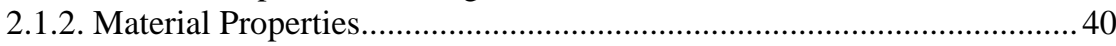

2.1.3. Experimental Results and Discussion ..................................................... 42

2.2. Proposed Technique for Development of the Residual Strength........................51

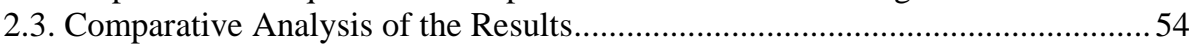

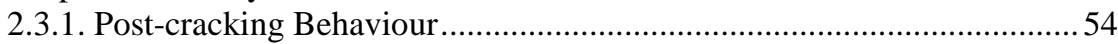

2.3.2. Determination of the $\sigma-w$ Law by Inverse Analysis ...............................57

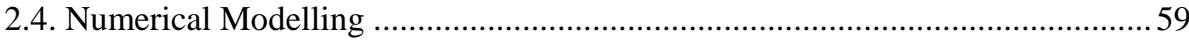

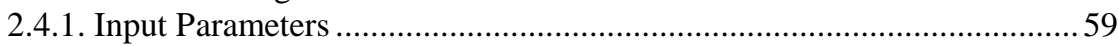

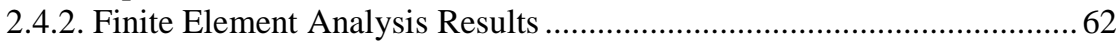

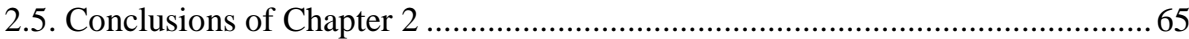

3. CRACKING AND DEFORMATION ANALYSIS OF STEEL FIBRE REINFORCED CONCRETE BEAMS WITH BAR REINFORCEMENT ...............67

3.1. Model Based on the Stress-transfer Approach.................................................68

3.1.1. General Assumptions and Basic Principles ................................................. 68

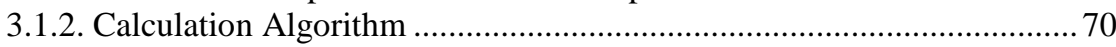

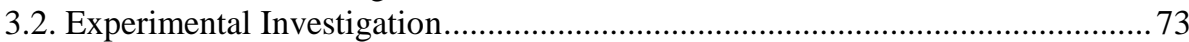

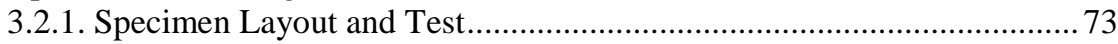

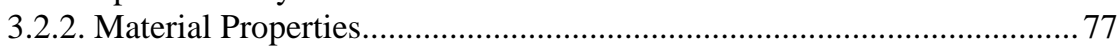

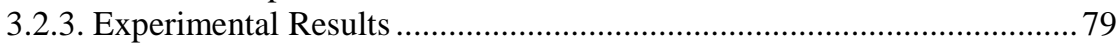

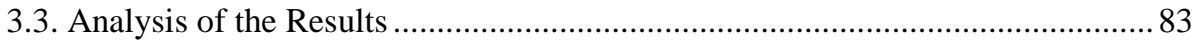

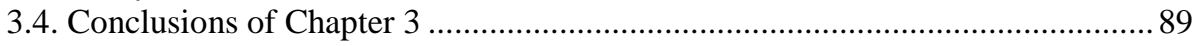

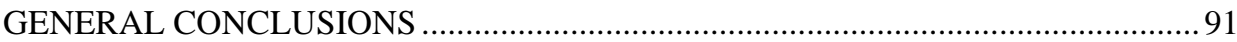

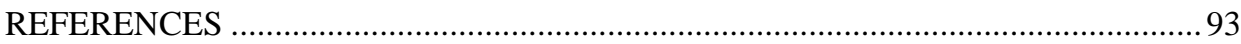

LIST OF SCIENTIFIC PUBLICATIONS BY THE AUTHOR ON THE TOPIC OF THE DISSERTATION . 


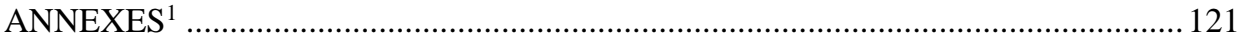

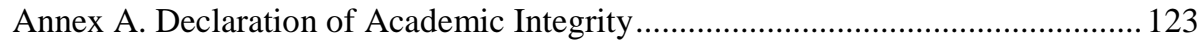

Annex B. The Co-authors' Agreements to Present Publications for the

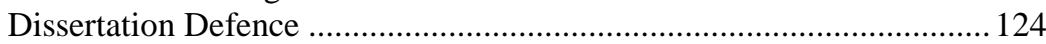

Annex C. Copies of Scientific Publications by the Author on the Topic of the Dissertation.................................................................................... 141

${ }^{1}$ The annexes are supplied in the enclosed compact disc 



\section{Introduction}

\section{Problem Formulation}

Steel fibre reinforced concrete (SFRC) is a cement based composite material reinforced with discrete, randomly distributed, fibres. A sufficient quantity of fibres (normally greater than $15-20 \mathrm{~kg} / \mathrm{m}^{3}$ ) added to the conventional concrete may have both technical and economic advantages, such as improved ductility, corrosion resistance and substantial reduction of laborious reinforcement work. Despite its extensive and long-term use in specific areas, e.g., industrial floors and underground shotcrete structures, SFRC has not occupied the general market of reinforced concrete structures. One of the main reasons is that the major design codes do not cover SFRC structures.

In some cases, fibres are used as the only reinforcement, while in other cases fibres are used in combination with a certain amount of conventional reinforcement. The derived material models of tensile SFRC, determined through standard test methods, are suitable for deformation analysis of SFRC elements without bars. However, their adequacy for the modelling applications of the serviceability state of SFRC elements with bar reinforcement still remains an issue and results in substantial errors. The present study is focused on the prediction of the postcracking behaviour of SFRC and serviceability analysis of flexural members with combined reinforcement of steel fibres and bars. 


\section{Relevance of the Thesis}

Steel fibre reinforced concrete structural elements are increasingly used in buildings and transport structures, such as bridges and tunnels. For the development of SFRC constructions with more structural responsibilities it is vital to understand the serviceability response of such elements. Until this day there are no generally accepted design guidelines for adequate prediction of deformations and cracking of SFRC members. In most cases, especially for engineering approaches, constitutive relationships are often simplified and do not reflect the complex nature of the material. The adequate definition of the residual strength of tensile SFRC as well as interaction between concrete and bar reinforcement leads to realistic cracking and deformation analysis of SFRC structures.

Based on the findings in the characterization of SFRC, a modelling approach to predict the flexural behaviour of SFRC elements with bar reinforcement is developed in this thesis. Experimental investigations and analytical calculations are performed in the present work for more accurate evaluation of cracking and deformation behaviour of SFRC structures.

\section{Object of Research}

The object of present study is deformation and cracking behaviour of flexural steel fibre reinforced concrete members subjected to short-term static loading.

\section{Aim of the Thesis}

The aim of the thesis is to propose a method for the prediction of deformation and cracking behaviour of SFRC beams with bar reinforcement.

\section{Tasks of the Thesis}

In order to achieve the objective, the following tasks have to be solved:

1. To analyse constitutive modelling methods of tensile SFRC.

2. To perform the experimental investigation on residual strength of tensile SFRC implementing standard three-point and four-point bending tests.

3. To propose a technique for assessment of the residual strength from the test results of standard beams.

4. To analyse the adequacy of the residual strength models. 
5. To perform the experimental investigation on cracking and deformation behaviour of SFRC beams with bar reinforcement.

6. To develop an algorithm based on the stress-transfer approach and perform the serviceability limit state analysis of flexural SFRC elements with bar reinforcement.

7. To evaluate the adequacy of the developed algorithm comparing cracking and deformation modelling results with obtained experimental data.

\section{Research Methodology}

Seeking to achieve the aim of the thesis, the analytical, numerical and experimental methods are applied in the present research. Experimental methods were performed to study the residual strength of SFRC as well as deformation and cracking behaviour of SFRC beams with bar reinforcement. Deformation and cracking analysis of SFRC beams with bar reinforcement is performed by the algorithm based on the stress-transfer approach. The residual strength of SFRC in tension is also investigated analytically and numerically using a standard FE software.

\section{Scientific Novelty of the Thesis}

1. A new modelling technique based on the stress-transfer approach is proposed for the assessment of deformation and cracking behaviour of flexural SFRC elements with bar reinforcement.

2. As an alternative to the constitutive modelling methods proposed in the design guidelines, a new method for the determination of the residual strength of SFRC in tension has been proposed.

3. New experimental data on deformations and cracking of SFRC beams with bar reinforcement, subjected to short-term loading, has been obtained.

\section{Practical Significance of Achieved Results}

The serviceability limit state of SFRC elements can be adequately assed by the proposed stress-transfer method. The suggested algorithm can be universally applied to any type of concrete (plain, fibre, high strength) and reinforcement (steel, 
fibre reinforced polymer). The application of these aspects in the design procedure leads to more efficient and cost-saving SFRC structures.

An extensive experimental program on standard and full scale beams allows to evaluate the adequacy of different constitutive laws and proposed algorithms for the serviceability analysis of SFRC elements.

\section{The Defended Statements}

1. The inverse algorithm proposed by the author adequately models the residual strength of steel fibre reinforced concrete.

2. The residual strength of SFRC based on the standard flexural tests is not capable to secure adequate serviceability analysis of SFRC beams with bar reinforcement.

3. The proposed modelling technique based on the stress-transfer approach allows to adequately model cracking and deformation behaviour of flexural SFRC elements with bar reinforcement.

\section{Approval of the Results}

The results of the thesis have been published in 14 publications, 5 of them in the journals with an Impact Factor and 3 in the conference proceedings referred by the Clarivate Analytics Web of Science. The author has made 9 presentations at 7 scientific conferences:

- 11th International Conference „Numerical Analysis and Applied Mathematics“, Rhodes, Greece, 2013.

- 7th International Conference „Fibre Concrete 2013“, Prague, Czech Republic, 2013.

- 16th Lithuanian Conference of Young Scientists Science - Future of Lithuania, Vilnius, Lithuania, 2013.

- 11th International Conference „Modern Building Materials, Structures and Techniques", Vilnius, Lithuania, 2013.

- 15th Lithuanian Conference of Young Scientists Science - Future of Lithuania, Vilnius, Lithuania, 2012.

- 17th International Conference „Mechanics of Composite Materials“, Riga, Latvia, 2012. 
- 14th Lithuanian Conference of Young Scientists Science - Future of Lithuania, Vilnius, Lithuania, 2011.

\section{Structure of the Dissertation}

The dissertation is structured around three main Chapters.

Chapter 1 reviews a short historical development regarding the design and standardisation of SFRC, main classification, design approaches used to describe constitutive laws of the material. The main characteristics, factors and mechanisms that contribute to the properties of the material are discussed. A review of the different test methods that characterise the post-cracking behaviour of tensile SFRC is provided, with particular emphasis placed on the prism bending test. The main design techniques and guidelines used for analysis of post-cracking behaviour and deformations of SFRC flexural members are reviewed. Chapter 1 concludes in formulating of main objective and tasks of present investigation.

Chapter 2 presents the technique proposed by the author for prediction of residual strength from standard three-point bending tests. With the aim of identifying the residual stress-crack width responses at different combinations of steel fibre contents, an experimental program of 48 flexural SFRC elements is presented. Selected standard constitutive modelling techniques for the characterization of tensile SFRC are discussed. In order to evaluate the adequacy of proposed and standard techniques, a numerical analysis using nonlinear FE analysis software is carried out.

Chapter 3 describes a technique based on stress-transfer model develop by the author for cracking and deformation analysis of steel fibre reinforced concrete beams with bar reinforcement. The experimental investigation on cracking and deformation behaviour of 11 full scale SFRC beams with conventional reinforcement subjected to short-term loading is presented. To evaluate the adequacy of the developed algorithm comparison of cracking and deformation modelling results with obtained experimental data is described.

General conclusions summarise the present study. It is followed by an extensive list of references and a list of 14 publications by the author on the topic of the dissertation.

\section{Acknowledgements}

The author expresses his very great appreciation to his supervisor Dr Darius Bacinskas for his advice and support throughout this research. 
The author would like to express deepest gratitude to Prof. Dr Habil. Gintaris Kaklauskas for providing a great deal of encouragement and assistance along the way.

Guidance and motivation given by Dr Viktor Gribniak is greatly appreciated.

For the collaboration, support, and countless discussions the author is thankful to the staff and $\mathrm{PhD}$ students of the Department of Bridges and Special Structures. In particular, author would like to acknowledge Dr Aleksandr Sokolov and Dr Eugenijus Gudonis for the great assistance during the experimental part of the research. Deepest thanks goes to Dr Pui Lam NG for valuable comments and remarks on PhD thesis.

Gratitude is extended to Prof. Dr Joaquim Antonio Oliveira Barros from the University of Minho for the guidance and support through author's external stay in Portugal.

The financial support provided for the external research visit by the Research Council of Lithuania is gratefully acknowledged.

The author expresses his deepest gratitude to his mother Rita for love, care and continuous encouragement. 


\section{Characterization and Modelling of Steel Fibre Reinforced Concrete}

The main purpose of this Chapter is to give an overview of the literature and provide background to the analysis of steel fibre reinforced concrete (SFRC). This Chapter covers a short historical development regarding the research, application, design and standardisation of fibre reinforced concrete (FRC), main classification, possible modelling approaches used to describe constitutive laws of the tensile SFRC. The main characteristics, mechanisms and factors that contribute to the properties of the material are presented. A review of the different test methods, design techniques and guidelines that characterise the post cracking behaviour of SFRC is provided, with particular emphasis placed on the standard prism bending test. Serviceability behaviour modelling of SFRC elements with steel bars are discussed.

This Chapter includes the material presented in journal publication Meškėnas \& Rimkus (2013) and conference proceedings Meškènas \& Ulbinas (2011), Gribniak et al. (2011), Meškènas \& Gelažius (2012), Meškėnas et al. (2013b), Rimkus \& Meškènas (2013a) and Rimkus \& Meškėnas (2013b). 


\subsection{Fibre Reinforced Concrete for Structural Applications}

\subsubsection{Development and Application}

In the past few decades, fibre reinforced concrete (FRC) has evolved to a widely used construction material as an improvement or alternative to the either plain or traditionally reinforced concrete. Significant research has been done and a number of real projects have been completed up to date. At present, fibre reinforced concrete is used worldwide in a large field of applications.

Plain concrete is characterized by excellent load carrying capacity in compression but also by brittle behaviour in tension. When the tensile stress for plain concrete exceeds the tensile strength, cracks start to develop. Rapid propagation of a single relatively small crack can often lead to a failure. The concept of employing fibres to improve the matrix characteristics is as old as adding straw or horsehair to mud bricks in Babylonian and Egyptian times (Naaman 2007). The introduction of fibres into concrete was originally intended to enhance the tensile strength of the concrete matrix, by postponing the widening of micro-cracks. The fibre reinforcement allows to carry a considerable amount of load after the cracking of a cement matrix has occurred. With early research works performed by Romualdi \& Mandel (1964), Shah \& Rangan (1970, 1971), Aveston \& Kelly (1973), Swamy et al. (1974), Naaman \& Shah (1975, 1976, 1979), Shah \& Naaman (1976) and Hannant (1978), it became evident, that the addition of fibres significantly increases the post cracking energy absorption (material toughness) characteristics of the brittle concrete, without significantly affecting the cracking strength of the matrix.

With the aim to improve the labour conditions and work efficiency on construction sites as well as for production of the prefabricated structures, fibre reinforcement can be considered as an alternative to conventional steel bars. In certain types of structures, such as foundations and walls or slabs on grade, ordinary reinforcement can be completely replaced by fibres. In other structural elements, such as beams or slabs, fibre reinforcement can be used in combination with traditional bars or pre-stressed reinforcement. In both cases the potential benefits result in the economic factors or the improvement of the labour efficiency at the construction site.

Regarding a structural aspect, the key reason for addition of the fibres to the concrete mixtures is to improve the structural behaviour and fracture characteristics. The ability of fibres to bridge the opening cracks influences both the serviceability and ultimate limit states. At the service load the beneficial effect is achieved with increased flexural stiffness, reduced crack width and crack spacing 
propagation. The behaviour in the ultimate limit state is influenced by the increased load resistance and in the case of shear and punching failures, the ductility of concrete (Shah \& Rangan 1971, Grzybowski \& Shah 1990, Stang \& Aarre 1992, Thomas and Ramaswamy 2007, Barros and Figueiras 1999, di Prisco et al. 2009). However, the addition of fibres has little effect on the behaviour of concrete before cracking (ACI 544.1R-96 2002).

During the last few decades, numerous investigations have been performed on material properties and behaviour characteristics of SFRC. Research on structural response of FRC elements was mainly developed during the last twenty years (Rossi \& Chanvillard 2000, RILEM TC 162-TDF 2002, di Prisco et al. 2004, Reinhardt \& Naaman 2007, Gettu 2008). Despite the increased awareness in practice and research, SFRC has been limited to use in non-critical load bearing members, even though significant potential exists for full or partial replacement of costly, manually placed, steel bar reinforcement. One of the reasons for limited use of fibre reinforced concrete in load-carrying structures seems to be the lack of internationally accepted design codes. This leads to the limited structural application of SFRC among engineers, even though a number of design guidelines were recently developed (RILEM TC 162-TDF 2002, JCI-S-002 2003, JCI-S-003 2007, CNR-DT204 2007, DBV 2007, EN14651 2007, ACI 544.1R-96 2002, DAfStbRichtlinie 2010, fib Model Code 2010). A more general utilization of fibre reinforced concrete in structural concrete structures requires more detailed design rules, combined with guidance regarding the optimum choice of fibre and concrete properties, implementation rules and test methods.

\subsubsection{Technology of Fibre Concrete}

A great variety of different cement based materials reinforced with fibres can be found being used for the practical applications. These include materials with considerably different material and mechanical properties as well as materials with different composition and structure. Observing from the early beginning of the concrete development, the progress has been huge, notably in the improvement of the strength properties (Li \& Fischer 2002, Dupont 2003). Furthermore, lately other material properties as workability, ductility and permeability have been recognised as equally important.

The main properties and characteristics designing high quality fibre reinforced concrete are related to the fibres. There is a number of different types and geometries of fibres that can be used to improve properties of concrete (EN14651 2007, ACI 544.1R-96 2002, Model Code 2010 2013). Hooked end steel fibres have been used for a decades, however recently developed steel fibres have more complex geometries (twisted, double hooked end) and higher slenderness and are made of high-strength steel. Further, synthetic fibres are becoming 
more popular as they can provide effective reinforcement comparable to that of steel fibres. Commonly used synthetic materials are glass, carbon, polyvinyl alcohol (PVA), polypropylene (PP) and cellulose. Mechanical and geometrical properties of fibres vary broadly, thus their effect on the properties of concrete can be considerably different. Some types of fibres are mainly used to reduce crack widths and improve the toughness, while others are there to reduce plastic shrinkage cracking or to avoid spalling of concrete during fire (Vandewalle 2000, Sorelli et al. 2006, Bentur \& Mindess 2007, Michels et al. 2012).

Fibres are considered as micro-fibres, when a cross-section diameter is of the same order as the cement paste grains or has a shorter length comparing to the maximum aggregate size. Fibres with the length exceeding the maximum aggregate size of the mix and with an aspect ratio (length to diameter) less than 100, are classified as macro-fibres (Naaman 2003, Bentur \& Mindess 2007). In general, macro-fibres increase the composite toughness by bridging the macro-cracks, while micro-fibres increase the resistance to micro-cracking (due to shrinkage or prior to the formation of macro-cracks).

This work focuses on fibres used for structural applications, and for this purpose slender high strength steel fibres are considered to be most efficient. The main characteristics that influence the mechanical properties of fibre reinforced composite are:

1. The fibre aspect ratio, defined as the ratio of the fibre length to fibre diameter $\left(l_{f} / d_{f}\right)$, has important influence for the effectiveness of fibre reinforcement. With the same fibre volume, a higher aspect ratio will lead to higher fibre surface area, therefore an improved bond reaction between the fibres and the matrix will appear. This leads to the effect of creating a stiffer matrix and improving composite actions (Johnston 2001). Experimental investigations conducted by Shah and Rangan (1971) showed that fibres with higher aspect ratio (same diameter but longer) produced steel fibre reinforced concrete (SFRC) with a slightly higher compressive and tensile strength, but significantly higher toughness. The higher the aspect ratio, the better the performance in both tension and compression. However, it is important to note, that with the increasing length of the fibres the workability of the concrete in the fresh state and consequently the ability to evenly distribute the fibres throughout the mix are diminished. Typically aspect ratios of 50 to 80 are used in past experimental works on SFRC (Vandewalle 2000, Dupont 2003, Lofgren et al. 2005, Campione 2008, Gribniak et al. 2012, Gribniak et al. 2013b).

2. Geometry and types of steel fibres available on the market vary in shape and size. The fibre shape and material are critical to the overall performance of the material composite. Fibres most often can be deformed at their ends, crimpled or twisted along their length in order to improve the pullout and bond characteristics. Many studies have shown that at the onset of failure, steel fibres tends to be 
pulled out from the matrix instead of rupturing (Salna 2008, Salna \& Marciukaitis 2010, Susetyo et al. 2011, Setkit 2012, Lee et al. 2012, Chalioris 2013). As a result, the mechanical anchorage from deformed fibres is critical in the overall response of SFRC. The most popular steel fibre geometries are hooked-end fibres. Typical steel fibre lengths vary from 10 to $60 \mathrm{~mm}$. Longer fibres are better at improving the post cracking behaviour of SFRC due to their ability to transfer load across the wide cracks with limited risk of pullout of the fibres, whereas short fibres are typically better at reducing the initial stage of cracking, i.e. micro-cracking. Various studies have shown improvements in overall response when shorter fibres were used (Susetyo et al. 2011, Deluce 2011). With the same fibre aspect ratio, shorter fibres will result in a significantly larger number of fibres required to achieve the same fibre volume fraction; this larger number of fibres would lead to improved crack bridging and better stress transfer across the cracks. Cross-sections are normally round while rectangular cross-sections are sometimes used. For round fibres, the cross-section diameter is typically in the range of 0.1 to $1 \mathrm{~mm}$ (Minelli 2005, Lofgren 2005, Naaman 2008).

3. One of the main parameters having influence on the behaviour of SFRC is the fibre volume fraction. Most of the typical tests on SFRC, such as the uniaxial direct tension test, flexural test and direct shear test, have shown that increase in fibre volume fraction will lead to improved toughness, ductility and strength (Shah \& Rangan 1971, Khaloo \& Kim 1997, Gribniak et al. 2012). As the fibre content increases, more fibres are likely to cross cracks, improving the matrix's ability to bridge cracks and enhance post-cracked behaviour. One of the first research performed by Shah \& Rangan (1971) showed that toughness, defined as the area under the load-deflection diagram, is significantly improved with increasing fibre content. This results in a significant increase in ductility. Typically fibre volume fractions in SFRC mixes are in the range of $0.25-1.5 \%$ by volume (20 to $120 \mathrm{~kg} / \mathrm{m}^{3}$ ) (Johnston 2001, Gribniak et al. 2012). Lower fibre dosages could be used in non-structural applications, where fibres are mainly used for crack control and overall durability, whereas higher fibre percentages (usually greater than $0.5 \%$ by volume) are often prescribed for structural applications.

4. Fibre orientation is an important factor influencing the behaviour of SFRC. Similarly to conventional reinforcement, fibres are most effective when being aligned parallel to the tensile stress direction, and are least effective when they are perpendicular to the tensile stress direction (Shah \& Rangan 1971). This is because the embedment length of the fibres and the number of fibres crossing a crack will decrease as the fibre angle becomes more oblique to the direction of the tensile stress. The efficiency of random fibre orientation is between the above two limiting conditions. In the modelling of SFRC, many account for the effects of fibre orientation and its impact on the efficiency of fibres through a so-called fibre orientation factor (Stroeven 1978, Schönlin 1988, Soroushian \& Lee 1990, 
Dupont 2003, Voo \& Foster 2003, Lee et al. 2011, Lee et al. 2012). This fibre orientation factor typically accounts for the fibre orientation angle, fibre dimensions, and member dimensions (Soroushian \& Lee 1990). In short, this factor is the average ratio of the projected fibre length in the direction of the tensile stress to the fibre length itself for all possible fibre orientations.

5. Workability of SFRC is another important parameter, which is mainly influenced by the paste volume fraction, the fibre dosage rate and the fibre aspect ratio. Typically, addition of fibres decreases slump, however this does not necessarily make fibre mixes harder to compact with vibration. At high fibre dosages the sand to coarse aggregate ratio in the concrete composition should be increased in order to obtain a satisfactory packing density. In some cases the balling effect can be observed if the limit fibre volume is reached for a maximum grain size (Bentur \& Mindess 2007, ACI 544.1R-96 2002). Considered fibres as an additional coarse aggregates in the mixture, the mix design of SFRC can be based on the same procedures as for plain concrete. However, it is recommended to increase the quantity of cement in SFRC compared to plain concrete, as fibres increase an internal surface, which needs to be moistened by cement paste. Therefore, the surface area of the specific fibre type should be considered in the design phase. Limitation of the maximum grain size also improves the workability of FRC (Ferrara \& Meda 2006, Ferrara et al. 2012).

6 . The performance of the SFRC is highly dependent on the bond strength between the fibres and the cement matrix. Although there are mechanical deformations at fibre ends (hooked end) that allow the fibres to have a mechanical anchorage into the cement matrix, the performance still relies on the bond and friction between the fibres and matrix after the onset of pullout. The strength of the matrix can affect the behaviour of SFRC, although to a lesser extent. It is well known that a higher compressive strength will produce a higher first crack tensile strength. However, the post-cracking behaviour of concrete is insignificantly influenced by the matrix's compressive strength (Thomas \& Ramaswamy 2007, Susetyo et al. 2011, Tiberti et al. 2014). Although a higher concrete strength can increase the bond strength, which is the interfacial shear strength between the fibres and the concrete, the fibres will also experience a higher interfacial shear stress at the onset of cracking due to the higher first cracking strength. Consequently, more bond slip may occur before fibres can be fully debonded, resulting in a similar post-cracked behaviour relative to lower strength SFRC (Susetyo et al. 2011). As with the compressive strength of the matrix, the ultimate tensile strength of the fibres has limited influence over the behaviour of SFRC. A high tensile strength reduces the possibility of brittle concrete composite failure due to fibre fracture (Vandewalle 1999). Instead of rupturing, the fibres will be pulled out of the matrix, resulting in a more ductile failure mode with the strength of the 
composite being governed by the bond strength between the fibres and the concrete matrix. The ultimate tensile strength of the fibres is particularly important in high strength concrete. As the concrete matrix strength increases, the interfacial bond strength between the fibres and the matrix improves, resulting in an increased stress in the fibres (Vandewalle 1999, Carnovale \& Vecchio 2013). Therefore the best bonding performance can be achieved combining rational strength of concrete and the ultimate tensile strength of the fibres.

\subsection{Material Properties of Steel Fibre Reinforced Concrete}

\subsubsection{Compression}

Numerous researchers (Ezeldin \& Balaguru 1992, Hsu \& Hsu 1994, Someh \& Saeki 1994, Mansur et al. 1999, Nataraja et al. 1999, Bencardino et al. 2008, Rizzuti \& Bencardino 2014) have investigated the effect of steel fibres on the compressive behaviour of SFRC. In most of the researches it was stated, that moderate volumes of fibres do not influence the compressive strength significantly. However, addition of fibres causes a less brittle failure of compressive concrete.

The stress-strain behaviour of plain concrete shows a linear-elastic response up to around $30 \%$ of the compressive strength and continuing with non-linear gradual increase up to the compressive strength. It is further followed by strain softening behaviour until concrete failure takes place by crushing. The compressive concrete failure is mostly related to the failure in tension, as tensile stresses are acting in perpendicular direction to the compressive load. The cracking process starts as sharing of the aggregate-cement paste interface and further propagates into the concrete matrix. The cracking process develops with an increasing compressive load while cracks become parallel to the direction of the principal compressive stress (Neville 1997, van Mier 1997, Darwin et al. 2001).

Although the ascending branch of the compressive stress-strain relationship is only slightly altered by the addition of the fibres, fibre reinforced concrete demonstrates less abrupt descending branch of the stress-strain curve than plain concrete. This results in a significant increase in the ductility and toughness of the fibre reinforced concrete (Fig. 1.1). The main advantage of fibres is their capacity to resist the growth of the longitudinal cracks. However, the effect of fibres depends on the type, geometrical and mechanical properties of the fibres and the properties of the matrix. Generally it can be observed that steel fibres at reasonable dosages (less than $1 \%$ by volume) have no influence to the pre-peak properties, whereas the strain at crack localisation and the failure strain increase. However, 
application of microfibers or with the fibre dosages greater than $1 \%$ the compressive behaviour can be improved.

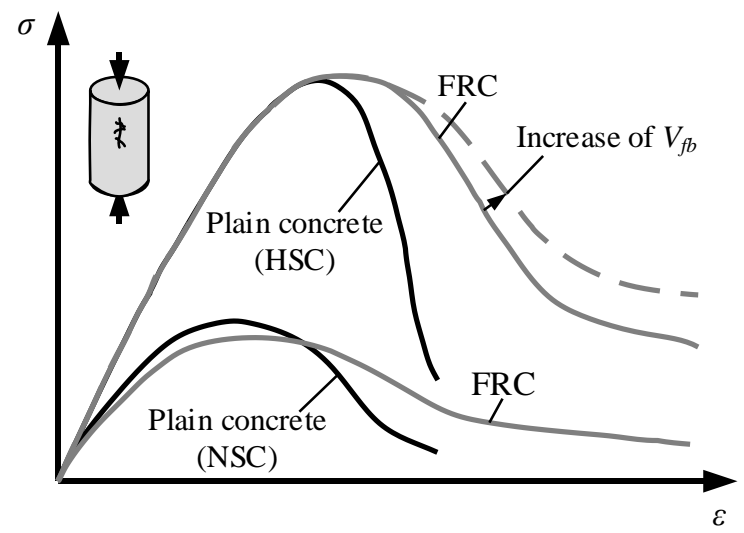

Fig. 1.1. Compressive stress-strain response of fibre reinforced concrete

Several researchers have proposed models for the characterization of the compressive stress-strain behaviour of SFRC. For structural design, elasto-plastic constitutive models with a parabolic transition have been proposed for the compressive behaviour of steel fibre reinforced concrete, with ultimate strains of 3.03.5\% (Lok and Pei 1998, ACI 544.1R-96 2002, RILEM TC 162-TDF 2003). In order to predict the compressive stress-strain response of SFRC, the measured compressive strength of SFRC is required in some models (Ezeldin \& Balaguru 1992, Nataraja et al. 1999), while in the other models (Hsu \& Hsu 1994, Someh and Saeki 1994, Mansur et al. 1999), the compressive strength of SFRC is derived from the compressive strength of plain concrete without fibres.

\subsubsection{Tension}

When subjected to tensile stresses, prior to cracking, the behaviour of plain concrete is approximately linear. Close to the peak stress, the overall response becomes softer due to micro-cracking and, as the tensile strength is reached with increased applied strain, a crack forms. Plain concrete, being a quasi-brittle material, can transmit tensile stresses, although at a low value, after cracking and is mainly attributed to aggregate interlocking (Walraven 1981, Petersson 1980, Cornelissen et al. 1986, Hordijk 1991, Elices et al. 2002). The specimens overall tensile resistance diminishes quickly to zero after the onset of cracking.

The tensile strength and modulus of elasticity of FRC are not significantly affected by the addition of fibres. However, the fibres have a considerable impact 
on the tensile fracture behaviour and the fracture energy. The random orientation of fibres greatly enhances the post-cracking resistance, thereby ensuring a more ductile failure. The most characteristic material behaviour for FRC is shown after reaching the limit of elastic behaviour. This boundary is commonly referred to as the limit of proportionality (LOP) and represents the initiation of the post-cracking residual strength of FRC. The shape of the post-cracking curves vary significantly, mainly depending on the type, orientation and number of fibres crossing the crack plane and the properties of the concrete (Naaman 2003a, Thomas \& Ramaswamy 2007).

It is generally accepted that the most appropriate and direct classification of the tensile behaviour is based on the uni-axial response (Hillerborg 1980, van Mier 1997, van Vliet \& van Mier 1999, van Mier \& van Vliet 2002, Löfgren 2005, Foster 2014). The tensile behaviour of cementitious materials can either be classified as strain-softening or strain-hardening (Fig. 1.2).

(a)

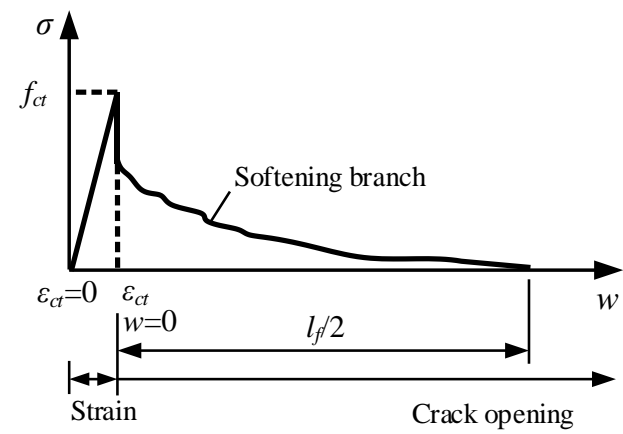

(b)

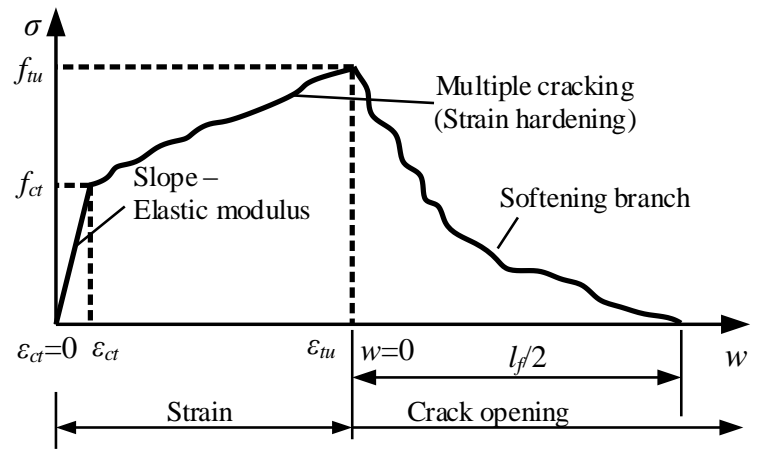

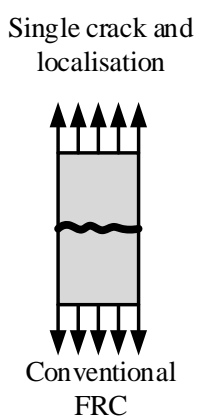

Multiple cracking and localisation

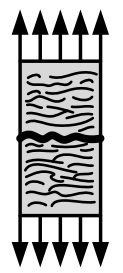

High performance FRC (HPFRC)

Fig. 1.2. Tensile stress-strain response of fibre reinforced concrete containing: (a) low fibre volume content and (b) high fibre volume content (Naaman 2003) 
For strain softening materials, failure occurs over a localised single dominant crack. The behaviour is characterised by the residual tensile strength of the specimen never reaching the tensile strength of the matrix after the limit of proportionality LOP (cracking), but tends to zero as the crack widens. Strain-hardening occurs when the post-cracking strength properties are higher than the elastic ones after the limit of proportionality LOP is reached. The residual stress increases after first cracking, and this may result in multiple cracking within the sample, which is then followed by failure at a localised crack. Based on this classification, tensile properties for strain-softening steel fibre reinforced concrete will be discussed in the thesis.

There are several methods that are proposed in the literature to study the tensile behaviour of FRC (Lim et al. 1987, Voo \& Foster 2003, Dupont 2003, Deluce \& Vecchio 2013). These include uniaxial tension test where the fracture toughness is used to characterize the post-peak behaviour of the material or the FRC is tested in bending to determine the flexural toughness properties.

\subsubsection{Residual Strength}

As mentioned in the previous Section, the most characteristic material behaviour for SFRC is shown after the cracking occurs. The carrying capacity of post-peak tensile stress of concrete is significantly enhanced due to the interaction between fibres and concrete across the cracks. The modelling of the descending portion of the tensile behaviour is essential for characterizing the material performance as well as for designs, involving impact and toughness resistance. However, quantification of the post-cracking strength of SFRC, also called as residual stresses, becomes a rather complicated issue due to diversity in the shape, material properties and bond characteristics of fibres (Li et al. 1993, Gribniak et al. 2012, di Prisco et al. 2013).

Once the concrete matrix has cracked, the fibres are able to transmit stress across the crack plane and provide some resistance to the opening of the crack. As the crack opening grows, the fibres gradually pull out of the matrix. The interaction between fibres and concrete, i.e. bond stress, increases, providing the residual strength over the crack opening. Therefore, contrary to plain concrete, rationally reinforced SFRC structures will not completely fail after crack. This results in the increase of fracture work capacity, also known as fracture energy or toughness of the concrete. Generally, fracture energy is represented as the area below the $\sigma-w$ curve (Fig. 1.3), which can be obtained either from direct tension tests or indirect bending tests discussed in Section 1.3. 


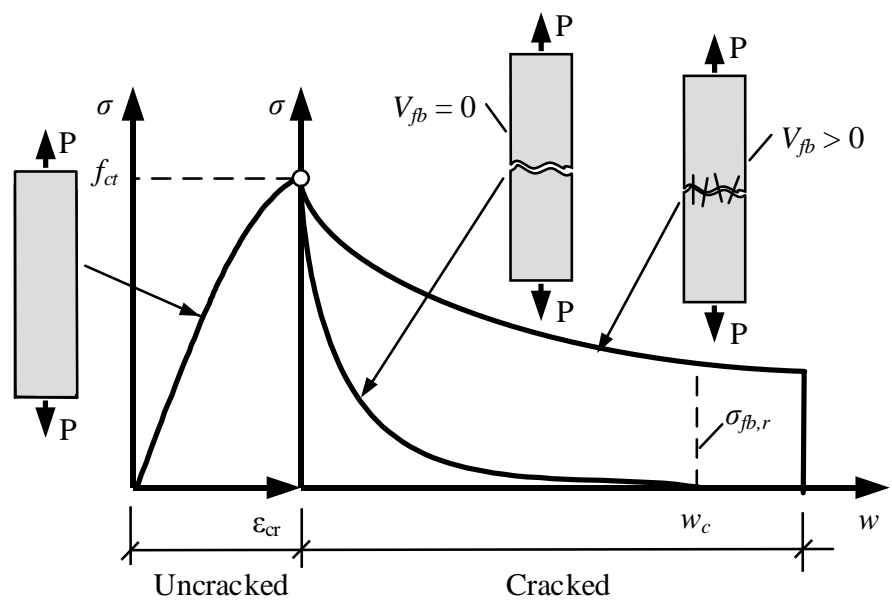

Fig. 1.3. Stress-strain and stress-crack width diagrams of tensile concrete

The stress-crack opening relationship can be separated into a concrete contribution and a fibre contribution. Contribution of the concrete is attributed to the softening stress-crack opening relationship for the plain concrete, while the fibre contribution consists of an increasing part followed by a descending part (for strain softening material behaviour). The first part of the combined behaviour (typically up to a crack opening of $0.1 \mathrm{~mm}$ ) is a result of the concrete softening and fibre contribution, while the relationship for larger crack openings results mainly due to the residual strength of fibres (Li et al. 1993, RILEM TC 162-TDF 2002a). The consequential total response consists of a tensile strength increase at small crack widths, followed by a descending or softening part (Fig. 1.4).

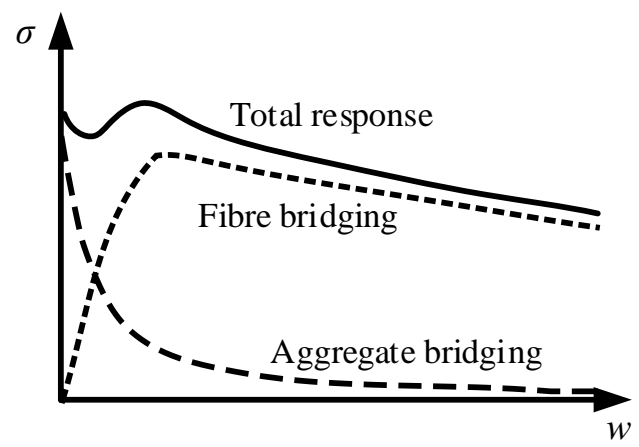

Fig. 1.4. Contribution of aggregate and fibre bridging actions to the stress-crack width diagrams of tensile concrete 
Concrete softening parameters were investigated by a number of researchers (Hillerborg 1980, Petersson 1980, Walraven 1981, Hordijk 1991). However estimation of softening parameters is an intricate problem, as the shape of the postcracking relationship heavily depends upon the properties of concrete. Therefore, for the simplicity, it is widely accepted to represent stress-crack relationship of SFRC as combination of both concrete and a fibre contribution.

\subsection{Constitutive Modelling of Steel Fibre Reinforced Concrete in Tension}

\subsubsection{Classification of the Test Methods}

In order to determine the material properties of SFRC, different test methods are specified in the design recommendations. The main difference between all the test methods, and the way they can be classified, is whether they are direct or indirect methods. In a direct method, material properties can be determined directly from the performed test results, e.g. uni-axial tension test. Whereas for an indirect method the test result has to be interpreted and derived using some accepted relationships (e.g. splitting tensile strength tests or flexural element tests for determination of the tensile strength). The other way to classify test methods is to separate between quantitative and qualitative methods. A quantitative method is aiming at determining physical properties while a qualitative method is aiming at comparing different mixes and compositions against a reference (e.g. comparing different fibres by evaluating energy dissipation or peak-load).

Several straightforward test methods can be used to determine the tensile behaviour of SFRC, directly or indirectly (Pereira et al. 2008, di Prisco et al. 2013). The direct tension test is considered to be the constitutive test that should be used in gathering the residual strength parameters of SFRC (Hillerborg 1980, van Mier 1997, van Vliet \& van Mier 1999, Kooiman 2000, van Mier \& van Vliet 2002, Löfgren 2005, Markovic 2006, Foster 2014). If the test is intended for determination of the uni-axial strength, the test should be performed on an un-notched specimen, while for the stress-crack width relationship after cracking, a notched specimen is recommended. However special care should be taken since the application of this test is not simple.

Typically, bending tests of prismatic beam specimens are the most typically used to characterize the post-cracking behaviour of SFRC. These can be either 3point bending tests (RILEM TC 162-TDF 2002a, JCI-S-002 2003, EN14651 2007, Model Code 2010, SS812310 2014) or 4-point tests (DBV 2007, JCI-S-003 2007, CNR-DT204 2007, DAfStb-Richtlinie 2010). The tested prism is subjected to either three- or four-point loading and in some cases can be equipped with a 
notch to control the crack localisation. Performing the bending test, both the axial tensile strength and the residual tensile strengths are derived using special formulas between flexural and uniaxial strengths. Alternatively, other methods can also be used for the material characterization, such as: round determinate panel tests (EN14488-5 2006, ASTM C1550-12a 2012), or splitting tensile tests (NT Build $5112005)$.

It must be noted that when inferring results from prism bending tests, the flexural bending behaviour differs greatly to that of uniaxial tension. In a flexural test, the response can either be deflection softening or deflection hardening (Fig. $1.5 \mathrm{~b}$ and $1.5 \mathrm{~d}$ ). But to complicate matters, it may happen that a material displaying strain softening behaviour in uniaxial tension (Fig. 1.5a) can exhibit either deflection hardening or softening behaviour in bending (Namaan \& Reinhardt 2006, di Prisco et al. 2009). Some authors (Stang \& Li 2004, Kanakubo 2006, Qian \& Li 2008) also have shown that the flexural response is strongly influenced by the dimensions of the sample. With a changing dimensions, e.g. height of the beam, the test results may be controversial, showing deflection hardening, or deflection softening for the same material.

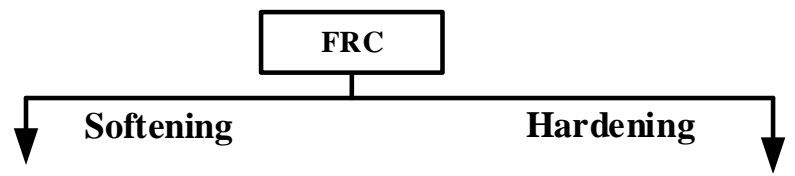

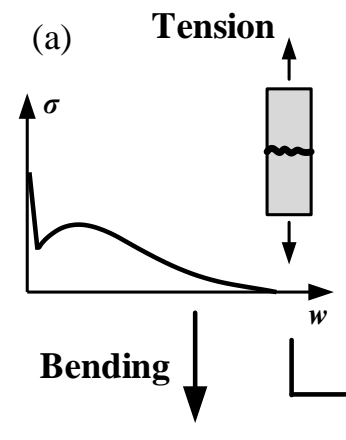

(c)

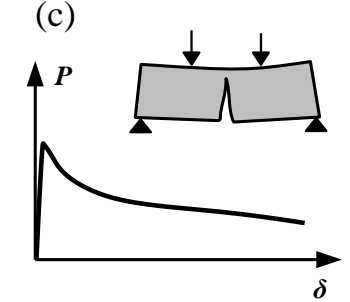

(b)

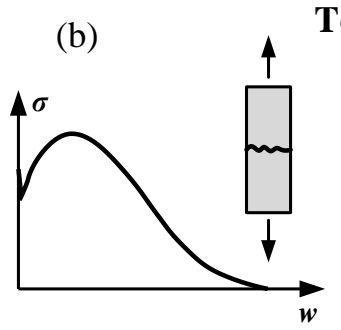

Tension (d)

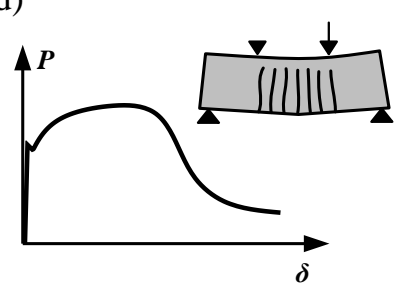

Fig. 1.5. Classification of steel fibre reinforced concrete test methods 


\subsubsection{Criteria and Characteristics}

The large variety of properties and parameters affecting the tensile response of SFRC make material modelling a particularly intricate task. Because of such complex behaviour, there is no unique constitutive law for its post-cracking response. Fundamentally there are two non-linear approaches for describing the behaviour of SFRC under tension: the stress-crack opening relation $(\sigma-w)$ and the stressstrain relation $(\sigma-\varepsilon)$ (Schnütgen \& Vandewalle 2003, Model Code 2010). Moreover, for investigation of post-cracking behaviour of SFRC both direct and inverse techniques can be used. The direct analysis is dedicated for the prediction of SFRC response using the specified material models, whereas the inverse analysis aims at determination of the parameters of a material model employing the constitutive test results (Banholzer et al. 2005, 2006, Marciukaitis et al. 2011, Kaklauskas et al. 2011).

To characterise the material behaviour in tension or flexure, stress-crack width $(\sigma-w)$ approach can be used, in which the tensile deformations after cracking are presented by the crack opening displacement. An opening crack can be modelled applying the fictitious crack model which was originally developed by Hillerborg et al. (1976) for cracking in plain concrete. This model considers a socalled cohesive zone on the fracture process of plain concrete in which stresses can be transferred over the crack plane. For plain concrete, the tension stresses drop to zero when interaction of the aggregate interlock ends. For steel fibre reinforced concrete, the fibres crossing the crack impose crack bridging effect. The stresses carried by fibres across a crack are described as a function of the crack opening. The tensile stress at the tip of the crack is assumed to be equal to the concrete tensile strength (Kullaa 1994, Lange-Kombak \& Karihaloo 1998, Li 1992; Li et al. 1993, RILEM TC 162-TDF 2002, Model Code 2010).

The stress-strain $(\sigma-\varepsilon)$ method may also be used to describe the softening behaviour of SFRC. Probably it is even more common way to represent the material behaviour both under tension and compression. It is widely used among structural engineers and designers, as it is straightforward approach for finite element analysis (Swamy \& Mangat 1974, Lim et al. 1987, Lok \& Xiao 1999). The characterisation of the $\sigma-\varepsilon$ law is based on the identification of a crack width and its corresponding structural characteristic length of the structural element (Bazant \& Oh 1983, RILEM TC 162-TDF 2003). In the linear-elastic stage the strains can be determined by dividing the measured deformation by the gauge length. However, after crack formation the measured deformation consists of the crack opening and the elastic deformation of the un-cracked part of the member within the gauge length. To convert the overall deformation into relative strain the characteristic length is suggested. This way, with the use of characteristic length, smeared crack models and discrete crack models can be translated into each other. Such representation can be seen in Fig. 1.6, which shows a schematic illustration of a steel 
fibre reinforced concrete constitutive diagram using both the $\sigma-\varepsilon$ and the $\sigma-w$ relationships to describe the post-cracking branch. However, determination of the characteristic length value is a diverse problem as it is influenced by several parameters, namely: type and amount of fibres, matrix strength, cross-section geometry, presence of conventional reinforcement, load level (RILEM TC 162-TDF 2002a, RILEM TC 162-TDF 2003, Dupont 2003, de Montaignac et al. 2012, fib Model Code 2010).

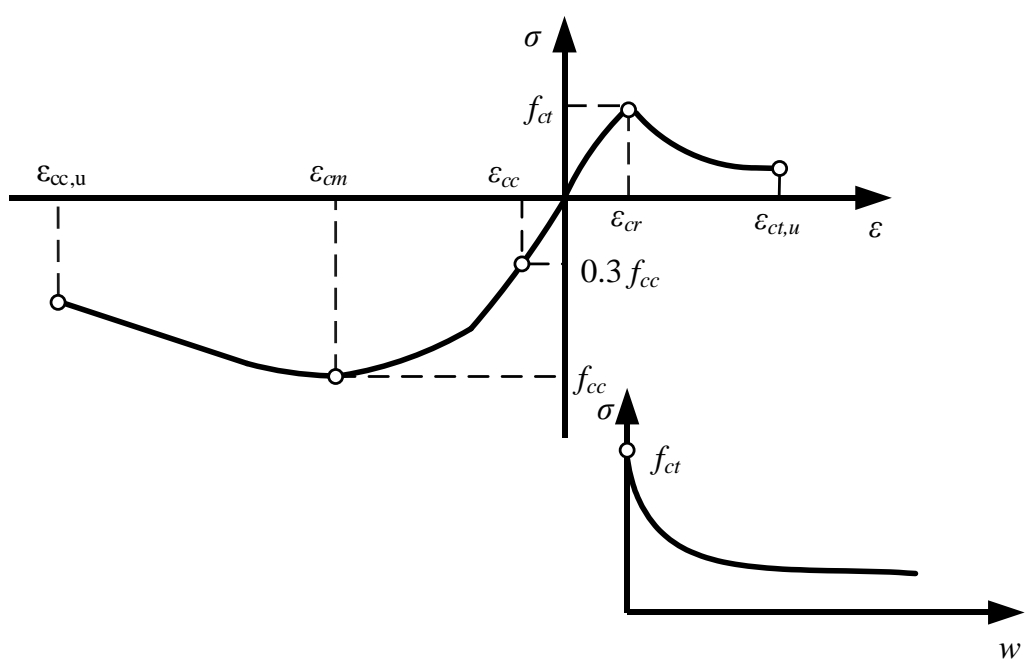

Fig. 1.6. Stress-strain and stress-crack width diagrams of steel fibre reinforced concrete

Direct analysis is the most straightforward approach for modelling the SFRC structures. The direct approach requires defining the shape of the constitutive relation in order to simulate the behaviour of the material. The parameters defining the constitutive law may be obtained either from experimental data, such as occurs in standards and guidelines (RILEM TC 162-TDF 2002a, JCI-S-002 2003, JCI-S003 2007, CNR-DT204 2007, DBV 2007, EN14651 2007, DAfStb-Richtlinie 2010, Model Code 2010), or from specific material properties (Li et al. 1993, Prudencio et al. 2006, Luccioni et al. 2012, Naaman 2003b). However, the reliability parameters due to scattering of the test results of SFRC and, therefore, material properties, makes this approach rather inaccurate.

The inverse analysis is based on an iterative procedure which fits experimental data in order to obtain the parameters that define an assumed shape for the constitutive diagram. Though the structural behaviour of SFRC elements can be reasonably fitted through such approach, there are several difficulties while using 
it. First of all, inverse approach needs experimental investigation of different combination of fibres and concrete properties. Moreover, SFRC properties from experiments in most cases differ from the ones in practical applications due to different production processes (casting, flow, vibration, etc.) that influence fibre distribution and orientation. The appropriateness of the experimental fitting depends on the assumed shape for the constitutive diagram and the prescribed deviation tolerance (Dupont 2003, Sousa \& Gettu 2006, Kaklauskas et al. 2011, Gribniak et al. 2012).

\subsubsection{Constitutive Models}

Despite the large amount of literature on the specific topics regarding design guidelines of SFRC structures, there is still an open discussion feeding doubts on the methods proposed by various Technical Committees (di Prisco et al. 2004). As there is no generally accepted constitutive law for structural design, the existing proposals in European Standards and guidelines should be analysed and discussed.

In a recent research conducted by Laranjeira (2010), Blanco et al. (2013), Yoo et al. (2015), a comparative analysis of constitutive models for fibre reinforced concrete was advanced. The authors covered the main features of the most relevant works in Europe, namely: the guidelines advanced by the RILEM Committee (RILEM TC 162-TDF 2002a, 2002b, 2003), German standards (DBV 2007, DAfStb-Richtlinie 2010), the Model Code 2010 (fib 2013) as well as the Italian standards (CNR-DT 204 2006). The shape and the parameters defining the proposed constitutive laws as well as their respective test methods is summarized in Table 1.1. It is shown, that the existing constitutive models are based on discontinuous equations and on an indirect approach since the parameters must be defined from experimental data. SFRC tensile behaviour is defined from a macroscopic perspective (i.e., irrespectively of the properties of its components) and both stress-strain and stress-crack width diagrams are proposed (Table 1.1).

Some of the presented design guidelines only refer to steel fibres (RILEM TC 162-TDF 2002a, 2002b, 2003 and DBV 2007), whereas the other guidelines distinguish between structural and non-structural fibres. This indicates a significant change in the design of fibre reinforced concrete structures since the variety of fibres that may be used for structural purposes are extended. Another common concept in the design guidelines is the size effect, which relates the specimen height effect to the overall bending behaviour. 
Table 1.1. Constitutive models of fibre reinforced concrete

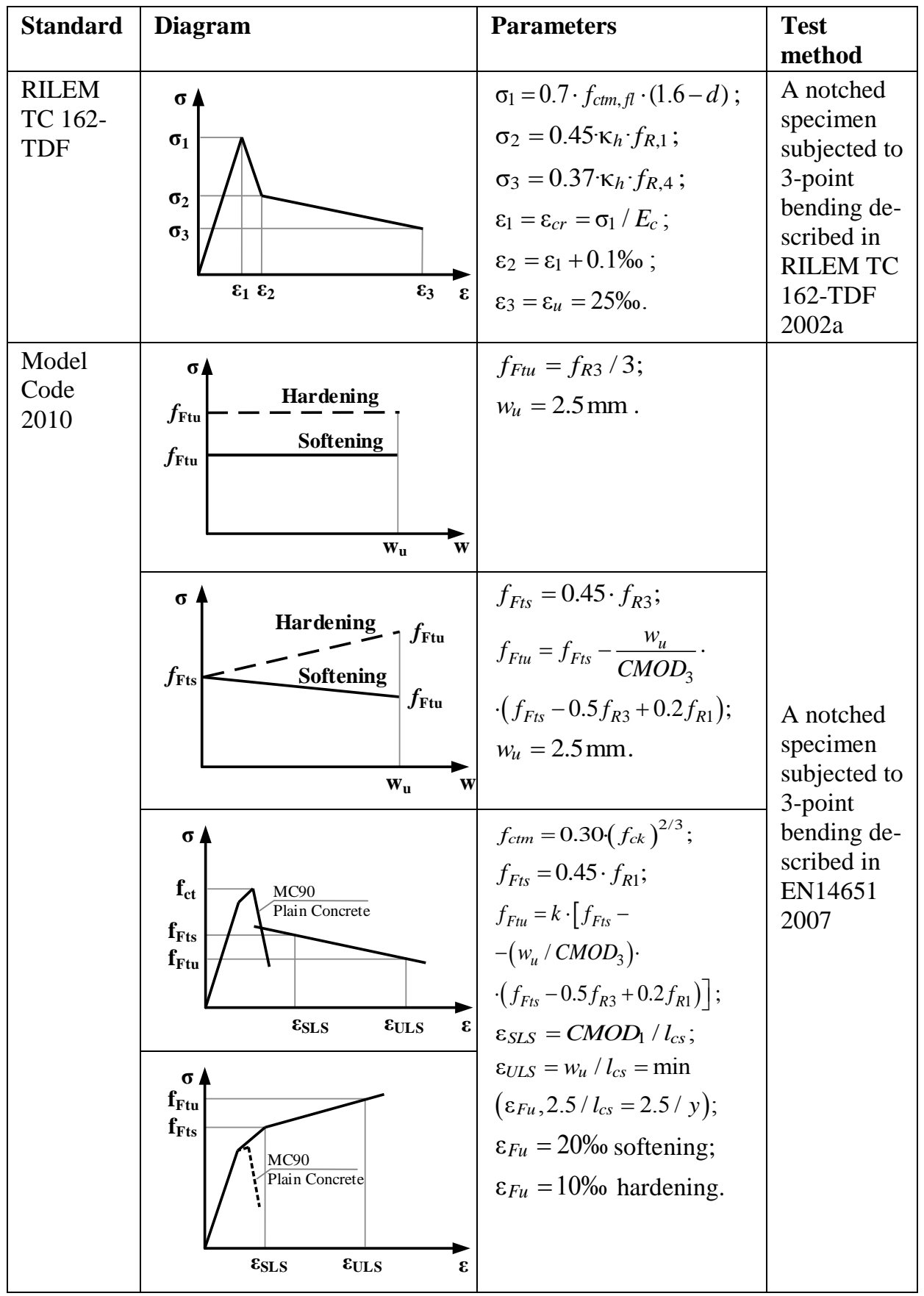


Continued Table 1.1.

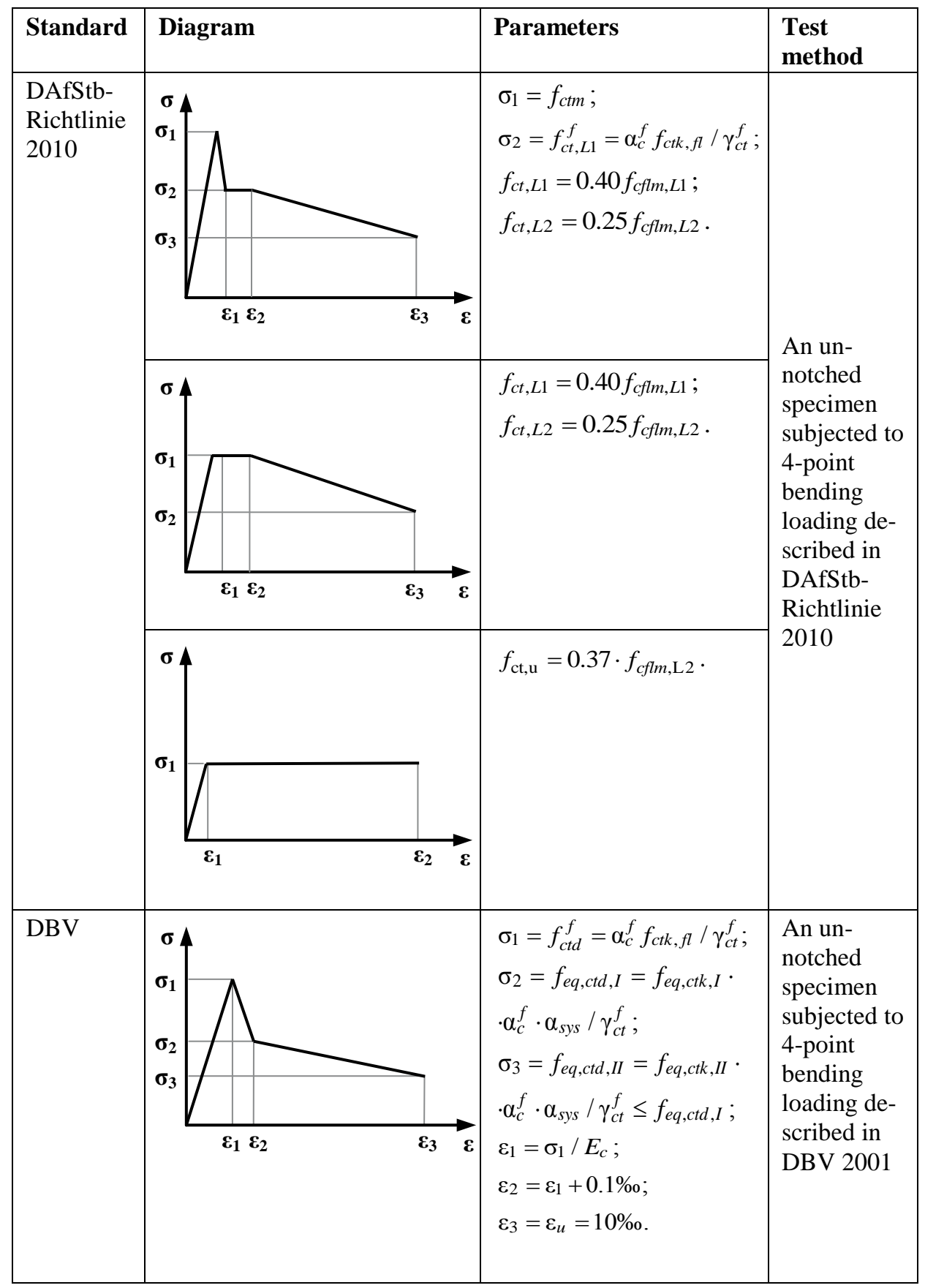


End of Table 1.1.

\begin{tabular}{|c|c|c|c|}
\hline Standard & Diagram & Parameters & $\begin{array}{l}\text { Test } \\
\text { method }\end{array}$ \\
\hline & $\sigma_{1}^{\sigma_{1}} \sigma^{\sigma_{2}}$ & $\begin{array}{l}\sigma_{1}=f_{e q, c t d, I}=f_{e q, c t k, I} \cdot \\
\cdot \alpha_{c}^{f} \cdot \alpha_{s y s} / \gamma_{c t}^{f} ; \\
\sigma_{2}=f_{e q, c t d, I I}=f_{e q, c t k, I I} \cdot \\
\cdot \alpha_{c}^{f} \cdot \alpha_{s y s} / \gamma_{c t}^{f} \leq f_{e q, c t d, I} \\
\varepsilon_{3}=\varepsilon_{u}=10 \% \mathrm{o} .\end{array}$ & \\
\hline & $\sigma \hat{A}$ & $\begin{array}{l}\sigma_{1}=f_{e q, c t d, I I}=f_{e q, c t k, I I} \\
\cdot \alpha_{c}^{f} \cdot \alpha_{s y s} / \gamma_{c t}^{f} \leq f_{e q, c t d, I} \\
\varepsilon_{3}=\varepsilon_{u}=10 \%\end{array}$ & \\
\hline \multirow[t]{2}{*}{$\begin{array}{l}\text { CNR-DT } \\
204\end{array}$} & $\sigma^{\sigma} \sigma_{1}$ & $\begin{array}{l}\sigma_{1}=f_{F t s}=0.45 \cdot f_{e q, 1} \\
\sigma_{2}=f_{F t u}=k \cdot\left[f_{F t s}-\right. \\
-\left(w_{u} / w_{i 2}\right) \\
\left.\cdot\left(f_{F t s}-0.5 f_{e q 2}+0.2 f_{e q 1}\right)\right] \\
\text { hardening: } \\
\varepsilon_{1}=\varepsilon_{u}=10 \% \text {; } \\
\text { softening: } \\
\varepsilon_{1}=\varepsilon_{u}=20 \%\end{array}$ & \multirow[t]{2}{*}{$\begin{array}{l}\text { A notched } \\
\text { specimen } \\
\text { subjected to } \\
\text { 4-point } \\
\text { bending de- } \\
\text { scribed in } \\
\text { CNR-DT } \\
2042006\end{array}$} \\
\hline & $\sigma$ & $\begin{array}{l}\sigma_{1}=f_{F t u}=f_{e q 2} / 3 \\
\text { hardening: } \\
\varepsilon_{1}=\varepsilon_{u}=10 \% \text {; } \\
\text { softening: } \\
\varepsilon_{1}=\varepsilon_{u}=20 \% \text {. }\end{array}$ & \\
\hline
\end{tabular}

There are a number of theoretical models based on inverse technique, however there are only few straightforward empirical methods for determination of post-cracking behaviour of tensile SFRC. One of the most widely applied methods was proposed by Naaman (2003b). This method assumes a constant law for residual strength of SFRC in tension. 
In the previous Section it was reviewed that for the evaluation of the residual strength, the effective content of fibres crossing the crack plane should be taken in consideration. The results of residual strength also depend on several factors, such as the orientation of fibres in the structure, the bond characteristics between fibre and concrete, the pullout length ratio, etc. To take these phenomena into consideration a simple analytical expression was suggested by Naaman (2003b). Residual strength is calculated taking into account the expected pullout length ratio, the efficiency factor of orientation in the cracked state, and the group reduction factor associated with the number of fibres pulling out per unit area:

$$
f_{f r}=\lambda_{1} \cdot \lambda_{2} \cdot \lambda_{3} \cdot \tau \cdot V_{f} \cdot \frac{l_{f}}{d_{f}} .
$$

Here $\lambda_{1}$ is the expected pullout length ratio; $\lambda_{2}$ is the efficiency factor of orientation in the cracked state; $\lambda_{3}$ is the group reduction factor associated with the number of fibres pulling out per unit area; $\tau$ is the average bond stress of a single fibre embedded in the concrete; $V_{f}$ is the steel fibre volume percentage; $l_{f}$ and $d_{f}$ are the length and diameter of fibre, respectively. Suggested values for steel fibres with aspect ratio up to 100 are: $\tau / f_{\mathrm{ct}}=2, \lambda_{1}=0.25, \lambda_{2}=1.2, \lambda_{3}=1$, as suggested by Naaman (2003b).

\subsection{Selected Standard Techniques}

To cover different testing techniques of three- and four-point bending tests as well as different constitutive models using stress-strain and stress-crack width approaches, RILEM TC 162-TDF (2003), Model Code 2010 (2013) and DAfStbRichtlinie (2010) techniques were selected for further analysis. To evaluate advantages, disadvantages and specific features of each selected test method, a detailed description of each method is given in further Subsections.

\subsubsection{RILEM TC 162-TDF}

RILEM TC 162-TDF (2003) committee has proposed the residual stress-strain method $(\sigma-\varepsilon)$ for defining the post-cracking behaviour of SFRC. The design parameters of the $\sigma-\varepsilon$ relation are determined by means of displacement controlled bending tests on notched prisms, as described in Subsection 2.1.1.

The stress is related to the fictitious strain in a certain region around the crack, and the parameters governing the post peak behaviour of a cracked SFRC are ob- 
tained by conducting beam bending tests that are either deflection or CMOD controlled. Average residual flexural tensile strength values $f_{R, i}(i=1-4)$ are determined as follows:

$$
f_{R, i}=\frac{3 \cdot F_{R, i} \cdot L}{2 \cdot b \cdot\left(h_{s p}\right)^{2}} .
$$

Here $F_{R, i}$ is the load recorded at $\mathrm{CMOD}_{\mathrm{i}}(0.5,1.5,2.5$ and $3.5 \mathrm{~mm})$ or deflection $\delta_{\mathrm{R}, \mathrm{i}}(0.46,1.31,2.15$ and $3.0 \mathrm{~mm})$, see Figs. $1.7 \mathrm{a}$ and $1.7 \mathrm{~b} ; L$ is the span of the specimen; $b$ is the width of the specimen; $h_{\mathrm{sp}}$ is the distance between the notch tip and the top of the specimen.

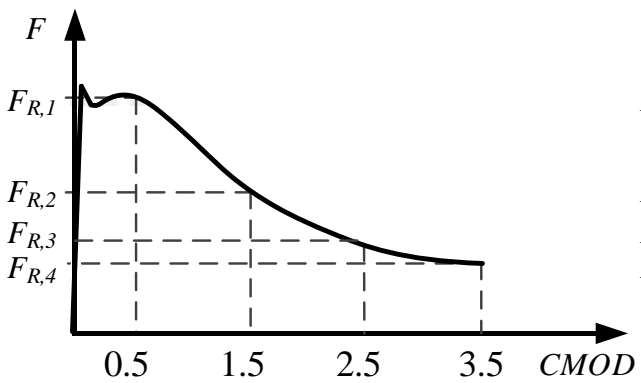

(a)

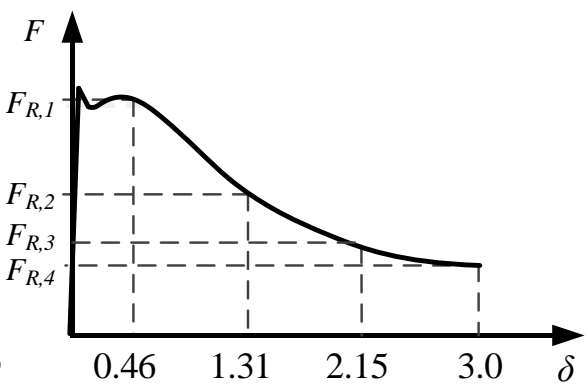

(b)

Fig. 1.7. Load-CMOD (a) and load-deflection (b) relationships

The stress-strain diagram adopted by RILEM is illustrated in Fig. 1.8a, where the stresses $\sigma_{2}$ and $\sigma_{3}$ are defined in terms of the residual flexural tensile stresses $f_{\mathrm{R}, 1}$ and $f_{\mathrm{R}, 4}$, which corresponds to crack mouth opening displacement (CMOD) of 0.5 and $3.5 \mathrm{~mm}$ of the three-point bending notched beam tests. The stresses shown in Fig. 1.8a can be evaluated using following empirical relationships:

$$
\begin{gathered}
\sigma_{1}=0.7 \cdot f_{f c t m, f l}(1.6-d) ; \\
\sigma_{2}=0.45 \cdot f_{R, 1} \cdot \kappa_{h} ; \\
\sigma_{3}=0.37 \cdot f_{R, 4} \cdot \kappa_{h} .
\end{gathered}
$$

Here $f_{f c t m}, f$ is the flexural characteristic tensile mean strength of the concrete; $\kappa_{h}$ is the size factor and can be evaluated from the diagram presented in Fig. 1.8b.

The value of ultimate strain $\varepsilon_{u}$ proposed by RILEM TC 162 -TDF committee is $25 \%$. This is the result of considering a height of the neutral axis of $140 \mathrm{~mm}$ above the point where the CMOD is measured and assuming a characteristic 
length equal to that distance. Consequently for a CMOD of $3.5 \mathrm{~mm}$, a strain value of $(3.5 / 140)=25 \%$ is obtained. Furthermore, the respective strains can be calculated as follows:

$$
\begin{gathered}
\varepsilon_{1}=\sigma_{1} / E_{c} ; \\
\varepsilon_{2}=\varepsilon_{1}+0.1 \% o
\end{gathered}
$$

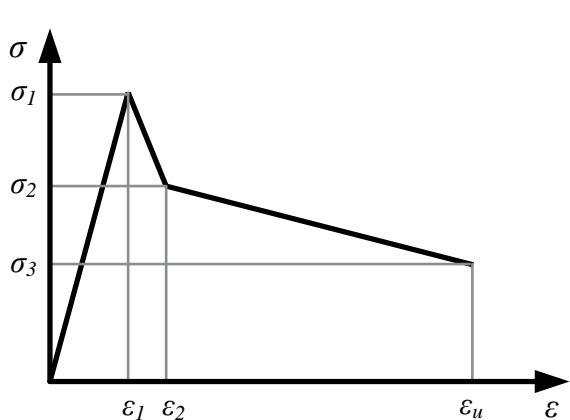

(a)

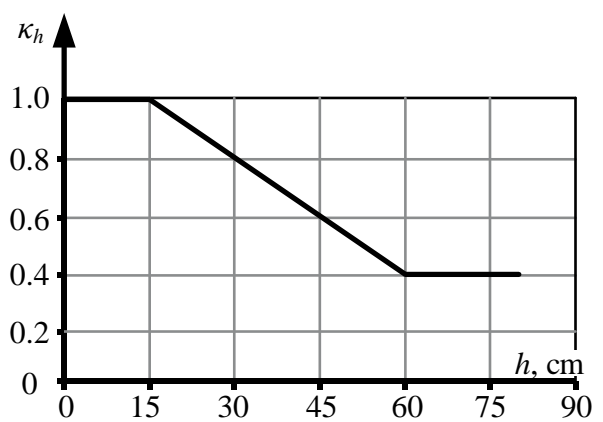

(b)

Fig. 1.8. Stress-strain diagram (a) and size factor (b) relationships

\subsubsection{Model Code 2010}

The recommendations of testing and mechanical characterization of steel fibre reinforced concrete provided in Model Code 2010 (fib 2013) emphasizes the importance of defining suitable material parameters for structural design, including post-peak tensile behaviour. With the aim of providing a tool for the design of SFRC structural elements, two different models for the tensile behaviour of FRC are proposed: the plastic-rigid and the linear-postcracking behaviours, shown in Fig. 1.9a and 1.9b, respectively. These models are presented in terms of simplified $\sigma-w$ constitutive diagrams and may reproduce both hardening and softening behaviour.

The parameters in both diagrams are defined by means of residual flexural tensile strengths, determined by performing a three-point bending test according to EN14651 (2007) or RILEM TC 162-TDF (2002a). According to the rigid plastic model the ultimate residual strength is defined as follows:

$$
f_{F t u}=\frac{f_{R 3}}{3} .
$$

Here $f_{R 3}$ is the residual flexural tensile strength recorded at $\mathrm{CMOD}_{3}=2.5 \mathrm{~mm}$ and calculated by Eq. 1.2. 


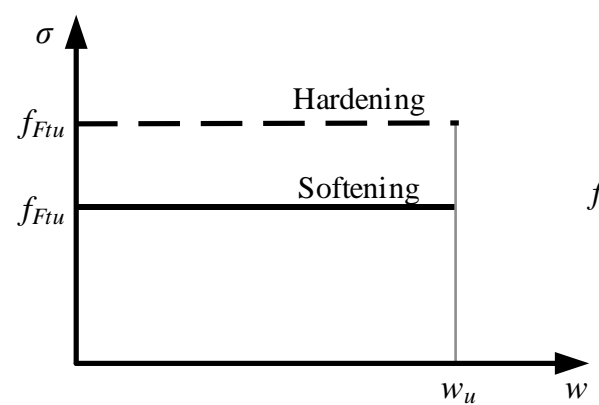

(a)

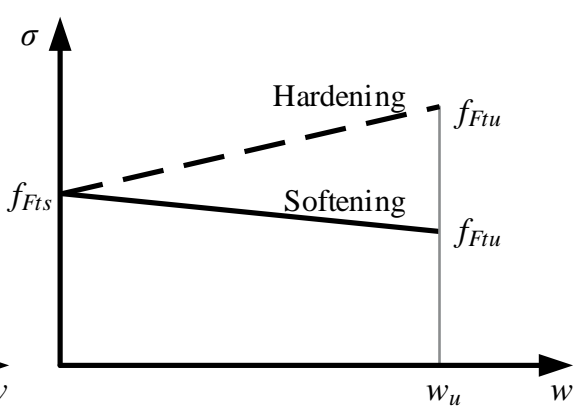

(b)

Fig. 1.9. Schematic illustration of the rigid plastic (a) and linear (b) models applied in Model Code 2010

On the other hand, two variables are defined in the linear model, $f_{F t u}$ and $f_{F t s}$. The former represents the ultimate residual strength and it is associated with the ULS crack opening $\left(w_{\mathrm{u}}\right)$, which is the maximum crack opening accepted in structural design (Eq. 1.9). The parameter $f_{F t s}$ represents the serviceability residual strength, defined as the post-cracking strength for crack openings at SLS and calculated according Eq. 1.10.

$$
\begin{gathered}
f_{F t u}=f_{F t s}-\frac{w_{u}}{C M O D_{3}} \cdot\left(f_{F t s}-0.5 \cdot f_{R 3}+0.2 \cdot f_{R 1}\right) ; \\
f_{F t s}=0.45 \cdot f_{R 3} .
\end{gathered}
$$

Here $\mathrm{CMOD}_{3}$ denotes the crack mouth opening displacement at a central displacement of $2.5 \mathrm{~mm}$. For the rigid-plastic model $w_{\mathrm{u}}$ is $2.5 \mathrm{~mm}$ and for the linear-elastic it depends on the ductility required but it will not exceed $2.5 \mathrm{~mm}$.

In order to define the stress-strain diagram it is necessary to distinguish between strain-softening and strain-hardening materials, presented in Fig. 1.10a and $1.10 \mathrm{~b}$, respectively. The stress levels $f_{F t s}$ an $f_{F t u}$ are calculated by means of Eq. 1.9 and Eq. 1.10. The corresponding strains at serviceability and ultimate limit states are determined by Eq. 1.11 and Eq. 1.12.

$$
\begin{gathered}
\varepsilon_{S L S}=\frac{C M O D_{1}}{l_{c S}} ; \\
\varepsilon_{U L S}=\frac{w_{u}}{l_{c S}}=\min \left(\varepsilon_{F u}, \frac{2.5}{l_{c S}}\right) .
\end{gathered}
$$

Here $\varepsilon_{S L S}$ is the strain considered in the SLS, $\varepsilon_{U L S}$ is the strain considered in the ULS, $l_{\mathrm{cs}}$ is the crack spacing length and $\varepsilon_{F u}$ is the ultimate strain taken as $2 \%$ for 
bending and $1 \%$ for uni-axial tension. The value of $l_{\mathrm{cs}}$ corresponds to the minimum between the average crack spacing $\left(s_{\mathrm{rm}}\right)$ and the distance between the neutral axis and the tensile side of the cross section $(y)$.

The curve suggested in the pre-cracking stage corresponds to the constitutive diagram for plain concrete until the intersection between the residual post-cracking behaviour (propagation of cracking), for strain-softening materials. This is indicated as "MC90 Plain concrete" in Fig. 1.10a. For strain-hardening another branch is proposed (see dash line in Fig. 1.10b).

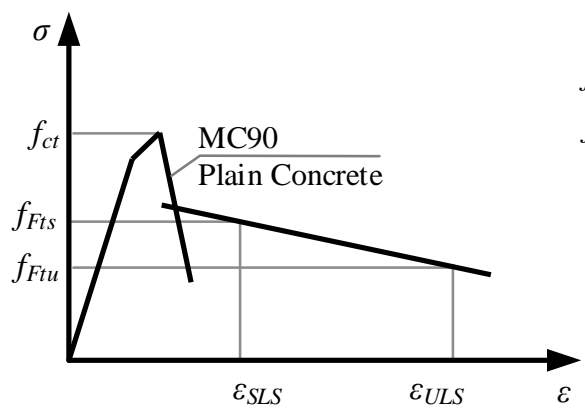

(a)

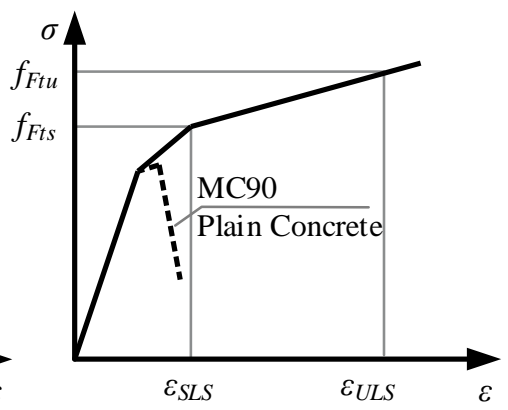

(b)

Fig. 1.10. Stress-strain curve laws for (a) strain-softening and (b) strain-hardening models applied in Model Code 2010

\subsubsection{DAfStb-Richtlinie}

The SFRC guideline proposed by the German committee for structural concrete (DAfStb-Richtlinie 2010), is based on the German code of practice for structural concrete, DIN 1045-1, and supplements the statements with the data necessary for steel fibre concrete. The guideline is valid for SFRC, for SFRC in combination with conventional reinforcement and pre-stressed SFRC for strength class up to C50/60.

From the four-point bending test, two values of the residual flexural tensile strength are determined. The first value, $f_{\mathrm{cflm}, \mathrm{L} 1}$, is determined at a deflection of

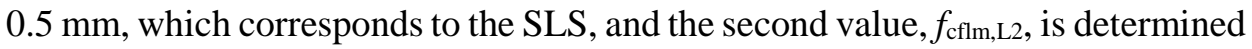
at a deflection of $3.5 \mathrm{~mm}$, referring to the ULS, see Fig. 1.11. Equations 1.13 and 1.14 give the both strengths:

$$
f_{\mathrm{cflm}, \mathrm{L} 1}=\frac{F_{0.5} \cdot l}{b \cdot h^{2}}
$$




$$
f_{\mathrm{cflm}, \mathrm{L} 2}=\frac{F_{3.5} \cdot l}{b \cdot h^{2}} .
$$

Here $F_{0.5}$ and $F_{3.5}$ are the loads recorded at a deflection $\delta_{0.5}$ and $\delta_{3.5}(0.5$ and $3.5 \mathrm{~mm}$ ), see Fig. 1.11; $l$ is the span of the specimen; $b$ is the width of the specimen; $h$ is the height of the specimen, the subscripts $L 1$ and $L 2$ specifies the performance class for a $\mathrm{CMOD}=0.5 \mathrm{~mm}$ and $\mathrm{CMOD}=3.5 \mathrm{~mm}$, respectively.

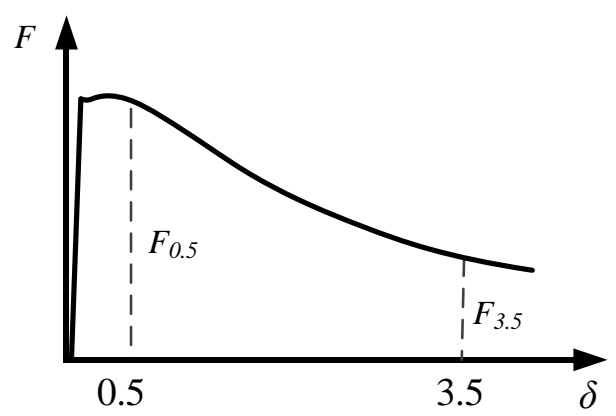

Fig. 1.11. Load-deflection diagram by DAfStb-Richtlinie 2010

For non-linear or extensive deformation analysis, the linear behaviour of the stress-strain relationship up to $f_{\text {ct }}$ should be considered (Fig. 1.12a). For the assessment of cross sectional forces and for approximate deformation analysis the linear progression up to $f_{\mathrm{ctm}}$ may be disregarded. Depending on the ratio $L 2 / L 1$ (DAfStbRichtlinie 2010), either the complete stress-strain relation (continuous lines) or the rectangular stress block (dashed lines) in Fig. 1.12b shall be used in the tension zone for the cross section design in ULS.

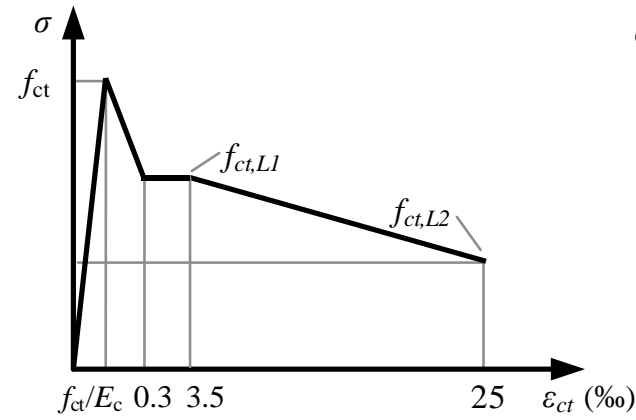

(a)

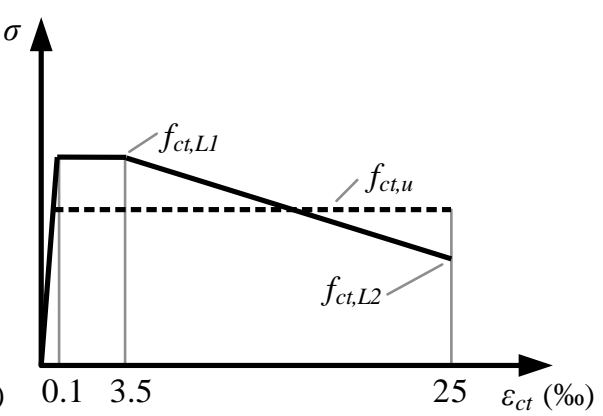

(b)

Fig. 1.12. Stress-strain diagrams by DAfStb-Richtlinie:

(a) complete and (b) simplified 
Based on performance class and the characteristic value of the residual flexural tensile strength, basic values for the residual tensile strength, $f_{c t 0, L i}^{f}$, are tabulated in DAfStb-Richtlinie (2010). Following the recommendations, the residual tensile strengths at predefined deflections are obtained by multiplying the corresponding residual flexural tensile strengths with given factors:

$$
\begin{aligned}
& f_{\mathrm{ct}, \mathrm{L} 1}=0.40 \cdot f_{c f l m, \mathrm{~L} 1} ; \\
& f_{\mathrm{ct}, \mathrm{L} 2}=0.25 \cdot f_{c f l m, \mathrm{~L} 2} ; \\
& f_{\mathrm{ct}, \mathrm{u}}=0.37 \cdot f_{c f l m, \mathrm{~L} 2} .
\end{aligned}
$$

The strain values used for design according to DAfStb-Richtlinie (2010), are obtained from an assumed relationship between the measured deflection and the length of the crack process zone. The strain is then obtained as the crack width divided by the length of the crack process zone. The ultimate strain is taken as $25 \%$.

\subsection{Modelling of Steel Fibre Reinforced Concrete Beams with Bar Reinforcement}

The majority of studies on SFRC have been concentrating on members containing steel fibres only, while in most practical applications of SFRC construction, structural members are reinforced both with SFRC and steel bar reinforcement. A combination of steel fibres and tensile reinforcing bars can bring together the advantages of both: the reinforcing bars carry the forces in the tension chord, while the steel fibres provide a confinement of the concrete cover, prevent spalling and carry multiaxial loads.

The derived material models of tensile SFRC, determined through standard test methods, are suitable for deformation analysis of SFRC elements without bars. However, their adequacy for the modelling applications of the deformation and cracking behaviour of SFRC elements with bar reinforcement still remains an issue and results in substantial errors (Vandewalle 2000, Gribniak et al. 2012, Deluce et al. 2014, Sahoo \& Sharma 2014).

A number of theoretical models have been proposed to predict serviceability behaviour of concrete elements with bar reinforcement. These models may be subdivided into such categories: stress-transfer approaches, fracture mechanics models and average stress-average strain approaches (Gribniak et al. 2013b). For the analysis of serviceability limit state, models based on stress-transfer (also called force transfer, or partial interaction) approach appear to be a reasonable alternative to commonly used code techniques, as it realistically predicts the 
cracking behaviour of reinforced concrete, bond-slip mechanics and the effect of tension stiffening (Jakubovskis et al. 2013, Sokolov et al. 2016).

When steel fibre and bar reinforcement are combined, the post cracking tensile capacity of the SFRC should be taken into account when calculating crack widths and spacing for the elements with bar reinforcement. In traditionally reinforced concrete members the crack width depends on the distance between cracks, i.e. crack spacing, and the distance between cracks is determined by the bond length of the reinforcing bars. At a crack section the tensile force in the plain concrete is zero with all the tensile force being carried by the steel bar reinforcement. Further from the crack the reinforcing bars bonded into the concrete matrix transfer tensile force into the concrete, with all the force being transferred into the concrete at a distance equal to the reinforcing bars development length. This distance in this research will be called as stress-transfer length $l_{t r}$. The minimum spacing between cracks is assumed to be equal to one stress-transfer length and the maximum spacing is two stress-transfer lengths. The maximum crack width will therefore result when the cracks are spaced at the maximum spacing of two development lengths. When bar reinforcement is combined with fibres bridging the crack the transmitted tensile stress across the crack is shared between the reinforcing bars and the fibres. This results in the smaller tensile force in the conventional reinforcement at the crack and, thus, the stress-transfer length of the steel is decreased. Reducing the stress-transfer length and the strain of the reinforcement decreases the crack spacing and, consequently, results in more cracks but with a smaller width (Fischer \& Li 2002, Deluce et al. 2014).

The essential aspect considering the stress-transfer models is the reinforcement bond-slip model used for analysis. A detailed survey of existing literature about the bond of ribbed reinforcing steel bars embedded in SFRC was carried out by Bigaj-van Vliet (2001), Dupont et al. (2002) and Plizzari et al. (2002). However, the existing studies on the effect of steel fibres on the bond behaviour of ribbed bars in concrete reported contradictory results. The performed studies are hardly comparable due to variations in mechanical and geometrical properties of the bar, steel fibre and concrete matrix properties. Therefore, up to present time, there is no clear agreement regarding the effect fibres to the overall bond-slip relationship.

The research performed by Cholmianskij (1981), Salem \& Maekawa (1999), Ruiz et al. (2007) shows that due to the damage of concrete close to the crack section bond deterioration occurs. Bond stress is rapidly reducing and is equal to zero in the section of the crack. The parts affected by the damage of the bond are further called as the damage zone. A number of damage zone models defined in the literature (Jakubovskis et al. 2013, Jakubovskis \& Juknys 2016) show that the length of the damage zone is related to the diameter of the steel bar reinforcement 
as well as the load level. The stress-transfer model developed in this thesis considers the bond-slip relationship given in Model Code 2010 (fib 2013). According to the Model Code 2010, the length of the damage zone is taken $l_{d}=5 \varnothing$. Within the length of the damage zone, the bond stresses are defined as:

$$
\tau=\tau_{\max } \cdot\left(s / s_{1}\right)^{\alpha} \cdot \lambda .
$$

Here $\lambda$ is the bond reduction factor. The Model Code 2010 assumes that $\lambda$ increases linearly from 0 in the crack to 1 in the end of the damage zone.

\subsection{Conclusions of Chapter 1 and Formulation of the Tasks of the Thesis}

Based on the literature review on constitutive modelling of steel fibre reinforced concrete, the following conclusions can be drawn:

1. Quantification of residual strength in tension is one of the most complex problems in the mechanics of the steel fibre reinforced concrete. This is mainly related to the varying fibre and concrete properties, diversity in the shape and type of fibres and, therefore, bond characteristics. For investigation of post cracking behaviour of SFRC, both direct and inverse techniques can be used. At this time, no single constitutive law is generally accepted to characterize the post-cracking behaviour of SFRC.

2. It is generally acknowledged that the constitutive laws of tensile SFRC are determined based on the experimental results on the standard flexural tests. However, the main drawback of this concept is that different standard test methods have been developed and moreover, several approaches are suggested in order to derive parameters which describe the residual strength of tensile SFRC.

3. The suggested simplified methods, such as the rigid-plastic or the fixed softening/hardening behaviour, do not provide sufficient information when a more detailed deformation analysis has to be made. Hence, it is desirable to know the complete stress-crack opening relationship in relation to the physical and mechanical phenomena involved.

4. For the analysis of serviceability behaviour of SFRC elements with bar reinforcement, the algorithm based on the stress-transfer approach can be used as an alternative to the simplified methods proposed in the recommendations. For adequate assessment of deformations and cracking, the residual strength and the constitutive laws characterising bond-slip and 
damage zone are considered as the basic constitutive parameters governing the results of analysis.

Taking into account the conclusions stated above, the main tasks addressed in this doctoral thesis are defined as follows:

1. Perform the experimental investigation on residual strength of tensile SFRC implementing standard three-point and four-point bending tests.

2. Based on the test results of standard beams, develop an algorithm for assessment of the residual strength.

3. To perform experimental investigation on deformation and cracking behaviour of SFRC beams with bar reinforcement.

4. To propose an algorithm based on stress-transfer approach and perform analysis of deformation and cracking behaviour of flexural SFRC elements with bar reinforcement.

5. Evaluate the adequacy of the developed technique comparing cracking and deformation modelling results with obtained experimental data. 



\section{2}

\section{Analysis of Residual Strength of Steel Fibre Reinforced Concrete}

This Chapter aims at analysing the residual strength of tensile SFRC. With the aim of identifying the post-cracking responses of SFRC at different combinations of steel fibre contents, an extensive experimental campaign of 48 standard flexural SFRC elements subjected to three- and four-point loading is presented. An algorithm for prediction of residual strength from standard three-point bending test is proposed by the author. The technique allows to define residual strength of SFRC at any loading or deflection of the flexural element. In order to evaluate the adequacy of the proposed and selected standard techniques for the quantification of residual strength of SFRC, a numerical analysis using nonlinear analysis FE software ATENA is carried out.

This chapter includes the material presented in journal publications Meškėnas et al. (2014a), Meškėnas et al. (2014b) and conference proceedings Meškènas et al. (2013a) and Kaklauskas et al. (2013). 


\subsection{Experimental Investigation}

\subsubsection{Selected experimental program}

The post-cracking behaviour of SFRC was experimentally assessed according to two different techniques: EN14651 (2007) and DAfStb-Richtlinie (2010) recommendations. The experimental program consisted of 48 SFRC beams, cast using 5 different concrete mixtures, containing from $23.5 \mathrm{~kg} / \mathrm{m}^{3}$ to $78.5 \mathrm{~kg} / \mathrm{m}^{3}$ hookedended steel fibres, equivalent to $0.3,0.5,0.6$ and $1.0 \%$ of the total specimen volume.

26 prismatic specimens of $150 \times 150 \mathrm{~mm}$ cross section and a length of $600 \mathrm{~mm}$ were tested under 3 point loading according to the procedure described in EN14651 (2007). The beams were notched on the face perpendicular to the casting surface. Wet sawing was applied through the width of the beam at its midspan. The width and depth of the notch was $5 \mathrm{~mm}$ and $25 \mathrm{~mm}$, respectively. The specimens were placed on roller supports, giving to the beam a free span of $500 \mathrm{~mm}$. Displacement controlled testing machine was used and beams were loaded with a rate of $0.2 \mathrm{~mm} / \mathrm{min}$. The tests were performed under crack mouth opening displacement (CMOD) control. For the measurement of CMOD, a linear variable displacement transducer (LVDT) was glued to the specimen and located at the bottom of the notch. In addition to the CMOD, the deflections on both sides of the beams were measured using LVDTs. The experimental set-up is shown in Figs 2.1 and 2.2.

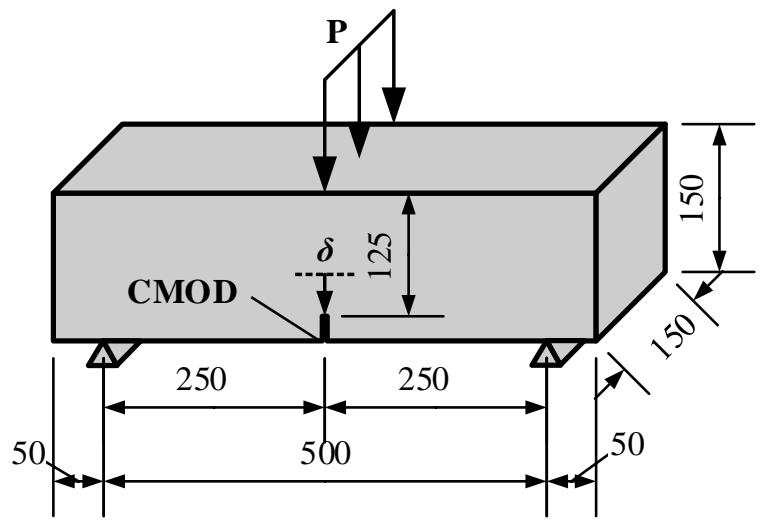

Fig. 2.1. Specimen geometry and loading scheme of the RILEM testing method 
Another 22 beams were casted and experimentally investigated according to recommendations described in DAfStb-Richtlinie (2010). Four-point bending tests (Figs 2.2 and 2.3) were performed on a prismatic specimens of $150 \times 150 \mathrm{~mm}$ cross section and a length of $700 \mathrm{~mm}$ (a free span of $600 \mathrm{~mm}$ ). The same displacement controlled testing machine (as for previously described test) was used and beams were loaded with a rate of $0.2 \mathrm{~mm} / \mathrm{min}$. The tests were performed under deflection control, measuring the deflections on both sides of the beams with LVDTs.

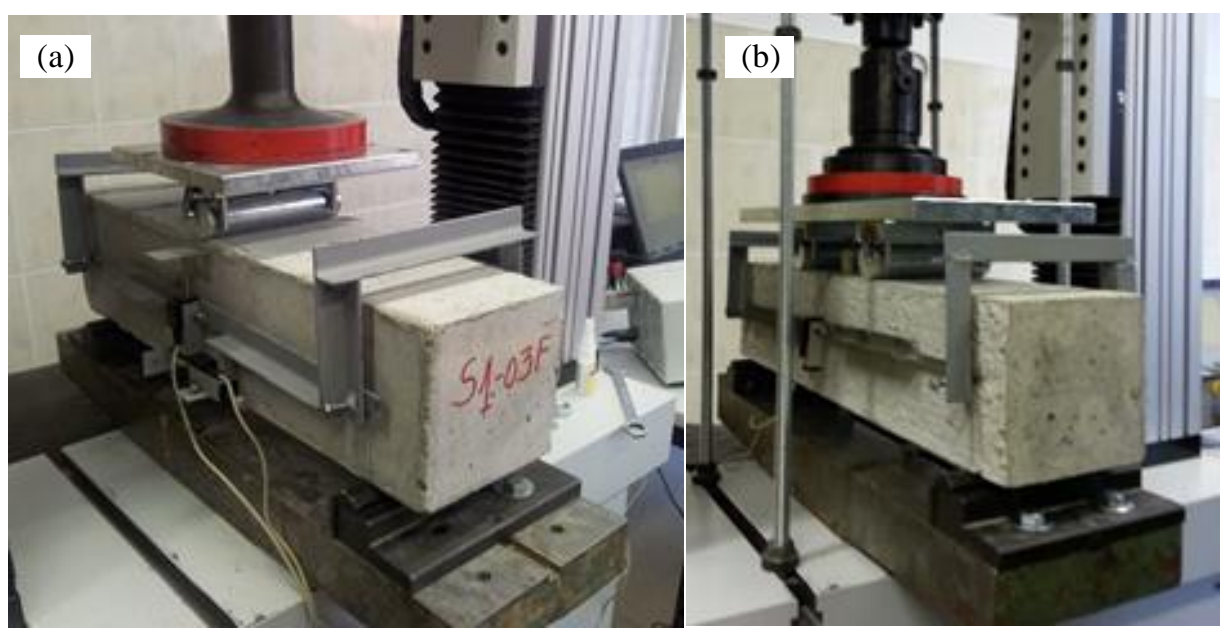

Fig. 2.2. Loading of steel fibre reinforced concrete element under (a) three and (b) four point bending loading

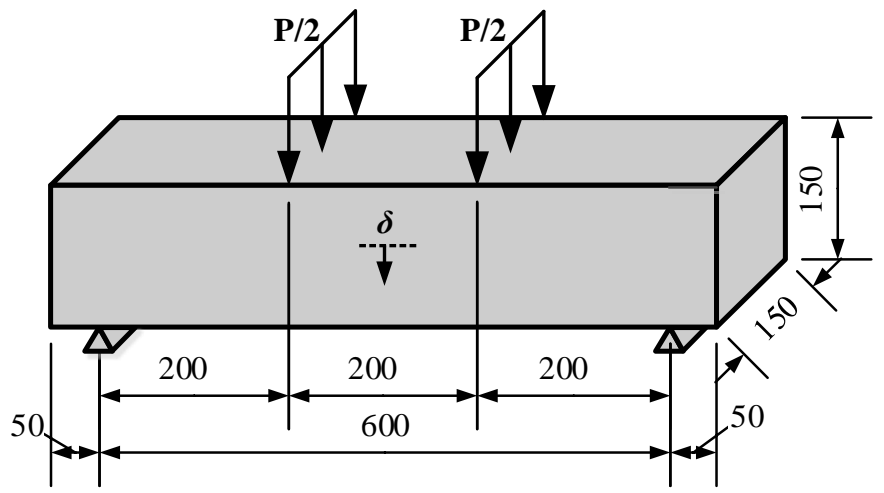

Fig. 2.3. Specimen geometry and loading scheme of the DAfStb-Richtlinie testing method 


\subsubsection{Material Properties}

Two concrete compositions were used in this research program for standard beams test performed under 3 and 4 point loading. Concrete mixtures had a target concrete compressive strength of $50 \mathrm{MPa}$ and $60 \mathrm{MPa}$ for Composition 1 and Composition 2, respectively. Although the use of the same concrete was certainly preferable for the same concrete strength, it was necessary to modify the mix design to accommodate the fibres due to problems associated with workability and homogeneity of the concrete mix.

The addition of fibres to the concrete mix is known to reduce concrete workability. Therefore, an adjustment had to be made to the composition of the concrete such that the requirements for compressive strength and workability are satisfied without any occurrence of segregation. The adjustment consisted of reducing the coarse aggregate content and increasing the fine aggregate content, the cement content, and the chemical admixtures content. Five different batches were mixed using different types and volumes of fibres. Beam series of Composition 1 were reinforced with 0.5, 0.6 and 1.0\% Duoloc hooked-ended steel fibres, equivalent to $39.3,47.1$ and $78.5 \mathrm{~kg} / \mathrm{m}^{3}$, respectively. Beam series of Composition 2 were reinforced with 0.3 , and $0.6 \%$ Mechel Nemunas hooked-ended steel fibres, equivalent to 23.6 and $47.1 \mathrm{~kg} / \mathrm{m}^{3}$, respectively. The dry compositions of all concrete mix designs used in this research per cubic metre are listed in the Table 2.1.

Table 2.1. Concrete compositions for $1 \mathrm{~m}^{3}$

\begin{tabular}{|c|c|c|c|c|c|}
\hline \multirow{2}{*}{ Ingredients } & \multicolumn{3}{|c|}{ Composition 1 } & \multicolumn{2}{c|}{ Composition 2 } \\
\cline { 2 - 6 } & FRC1 & FRC2 & FRC3 & FRC4 & FRC5 \\
\cline { 2 - 6 } & \multicolumn{5}{|c|}{ Amount, kg/m³ } \\
\hline Sand 0/4mm & 905 & 925 & 905 & 885 & 885 \\
\hline Crushed aggregate $5 / 8 \mathrm{~mm}$ & 388 & 380 & 388 & - & - \\
\hline Crushed aggregate 11/16 mm & 548 & 541 & 548 & - & - \\
\hline Crushed aggregate 4/16 mm & - & - & - & 975 & 975 \\
\hline Cement CEM I 42.5 N & 400 & 400 & 400 & 380 & 380 \\
\hline Concrete plasticizer & 1.8 & 2.0 & 1.9 & 1.7 & 1.7 \\
\hline Concrete retarder & - & - & - & 1.9 & 1.9 \\
\hline Water & 123.8 & 123.8 & 140.5 & 160 & 160 \\
\hline Duoloc fibres & 39.3 & 78.5 & 47.1 & - & - \\
\hline Mechel Nemunas fibres & - & - & - & 23.6 & 47.1 \\
\hline
\end{tabular}


For determination of the compressive strength and modulus of elasticity of SFRC, 15 concrete cylinders and 30 cubes were cast. The diameter and the height of the cylinders were $150 \mathrm{~mm} 300 \mathrm{~mm}$, respectively. The dimensions of the cubes were $150 \times 150 \times 150 \mathrm{~mm}$. Specimens were stored in a curing room (with a $100 \%$ relative humidity) for 28 days. Table 2.2 presents the compressive properties and the results of modulus of elasticity for both compositions. Figure 2.4 shows a concrete cube and cylinder being tested under compressive load.

Table 2.2. Concrete compressive strength and modulus of elasticity

\begin{tabular}{|c|c|c|c|c|c|}
\hline \multirow{2}{*}{ Parameter } & \multicolumn{3}{|c|}{ Composition 1 } & \multicolumn{2}{c|}{ Composition 2 } \\
\cline { 2 - 6 } & FRC1 & FRC2 & FRC3 & FRC4 & FRC5 \\
\hline$f_{c}$ & 55.62 & 47.95 & 60.12 & 65.30 & 62.27 \\
\hline$E_{c}$ & 38342 & 36733 & 38560 & 40346 & 39767 \\
\hline$V_{f b} \%$ & 0.5 & 1.0 & 0.6 & 0.3 & 0.6 \\
\hline
\end{tabular}
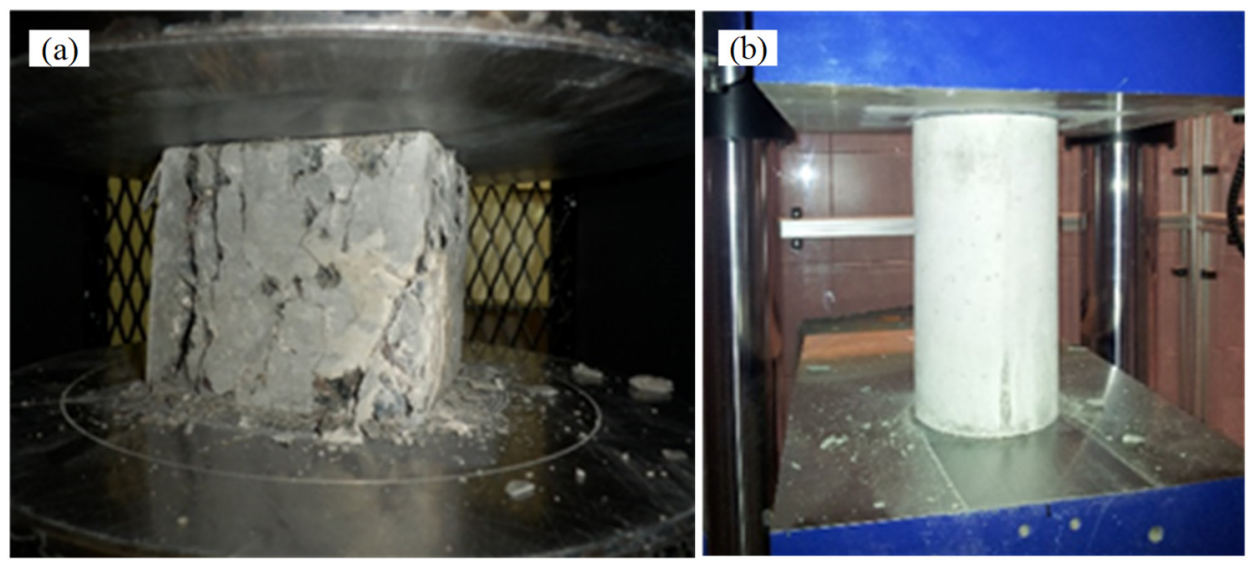

Fig. 2.4. Compression tests of (a) cube and (b) cylinder

In all performed tests hooked end steel fibres were used (Table 2.3). In the concrete Composition 1 Duoloc fibres with a length of $55 \mathrm{~mm}, 1.0 \mathrm{~mm}$ diameter $\left(d_{f}\right)$, an aspect ratio $\left(l_{f} / d_{f}\right)$ of 55 and a yield stress of $1020 \mathrm{MPa}$ were mixed (Fig. 2.5). For the Composition 2 concrete, Mechel Nemunas fibres, produced by Lithuanian company, were used. Fibres had a length $\left(l_{f}\right)$ of $50 \mathrm{~mm}$, diameter $\left(d_{f}\right)$ of $1.0 \mathrm{~mm}$, with an aspect ratio $\left(l_{f} / d_{f}\right)$ of 50 and a yield stress of $1100 \mathrm{MPa}$. 
Table 2.3. Characteristics of the steel fibres

\begin{tabular}{|c|c|c|c|c|}
\hline Fibre type & Length, $\boldsymbol{l}_{\boldsymbol{f}}$ & Diameter, $\boldsymbol{d}_{\boldsymbol{f}}$ & $\begin{array}{c}\text { Aspect ratio, } \\
\boldsymbol{l}_{\boldsymbol{f}} / \boldsymbol{d}_{\boldsymbol{f}}\end{array}$ & $\begin{array}{c}\text { Tensile yield } \\
\text { strength, } \boldsymbol{f}_{\boldsymbol{y}}\end{array}$ \\
\hline Duoloc & 55 & 1 & 55 & 1020 \\
\hline Mechel Nemunas & 50 & 1 & 50 & 1100 \\
\hline
\end{tabular}

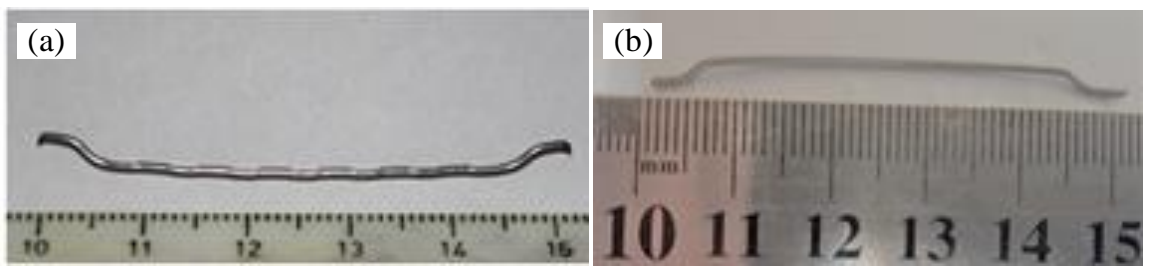

Fig. 2.5. Used steel fibres for dispersive reinforcement: (a) Duoloc fibres;

(b) Mechel Nemunas fibres

\subsubsection{Experimental Results and Discussion}

From the test results of 26 prismatic specimens subjected to 3 point loading, experimental load-crack mouth opening displacement (CMOD) and load-deflection curves were obtained. Graphs for series FRC1, FRC2, FRC3, FRC4 and FRC5 are presented in Figs. 2.6, 2.7, 2.8, 2.9 and 2.10, respectively. It can be observed that the variability in the obtained deformation responses is significant. Such a variety of results was mainly influenced by the orientation and number of fibres acting at the crack section.
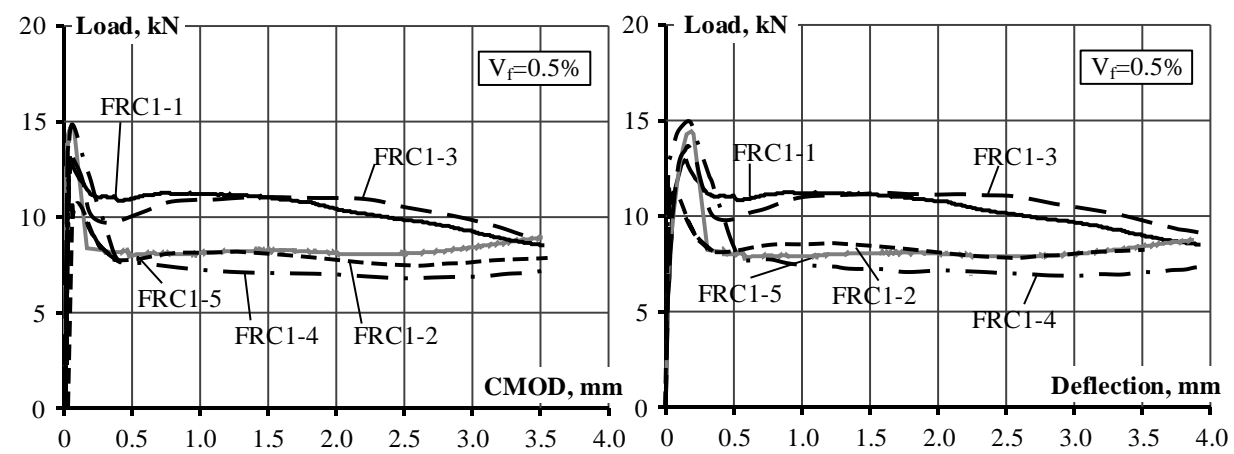

Fig. 2.6. Experimentally obtained load-CMOD and load-deflection diagrams of three-point loading FRC1 series beams 

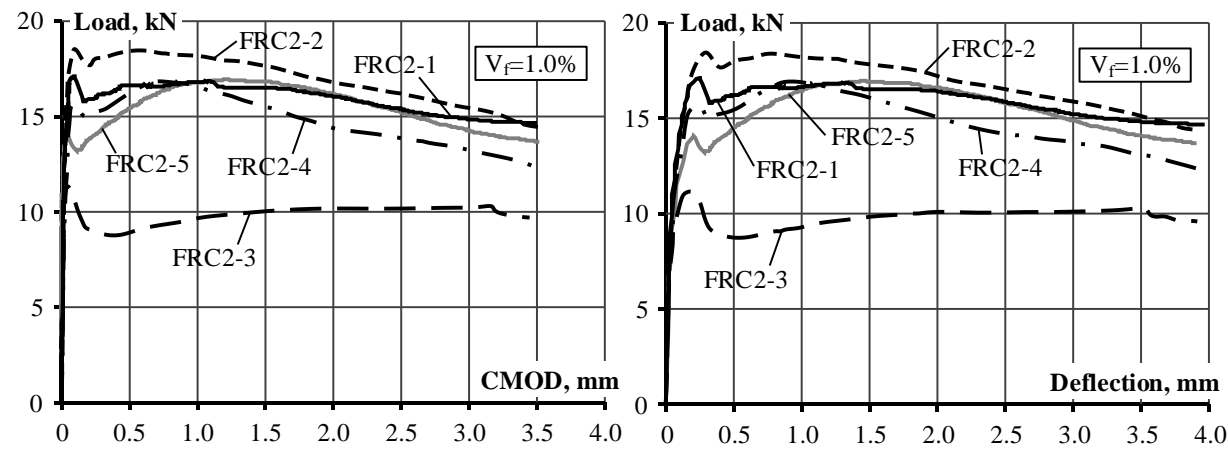

Fig. 2.7. Experimentally obtained load-CMOD and load-deflection diagrams of three-point loading FRC2 series beams
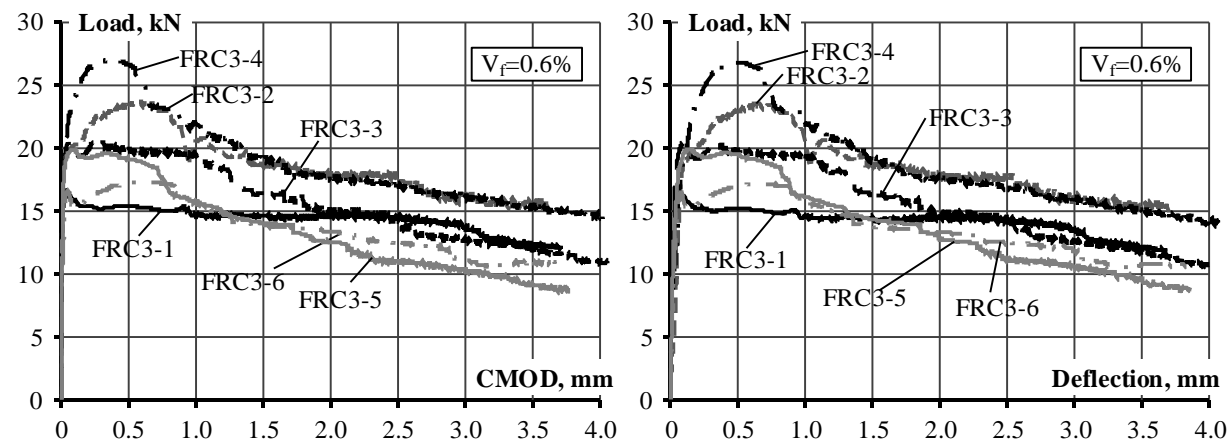

Fig. 2.8. Experimentally obtained load-CMOD and load-deflection diagrams of three-point loading FRC3 series beams
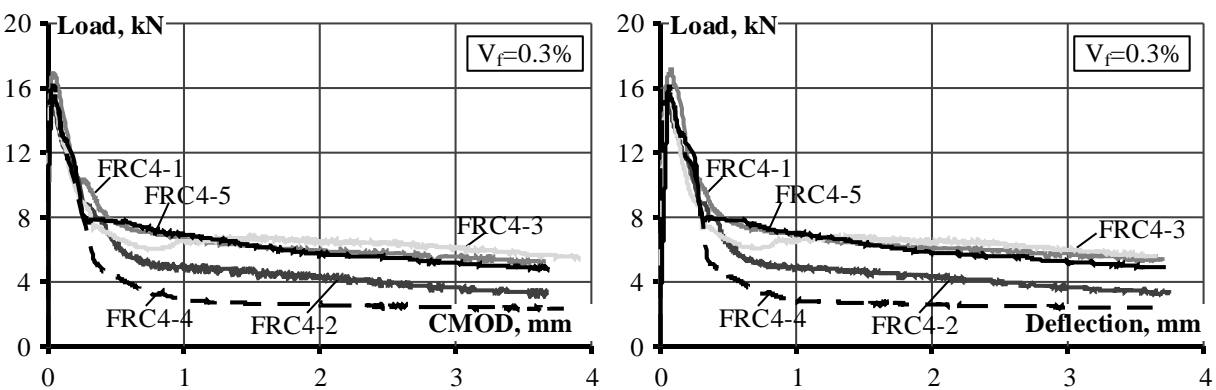

Fig. 2.9. Experimentally obtained load-CMOD and load-deflection diagrams of three-point loading FRC4 series beams 

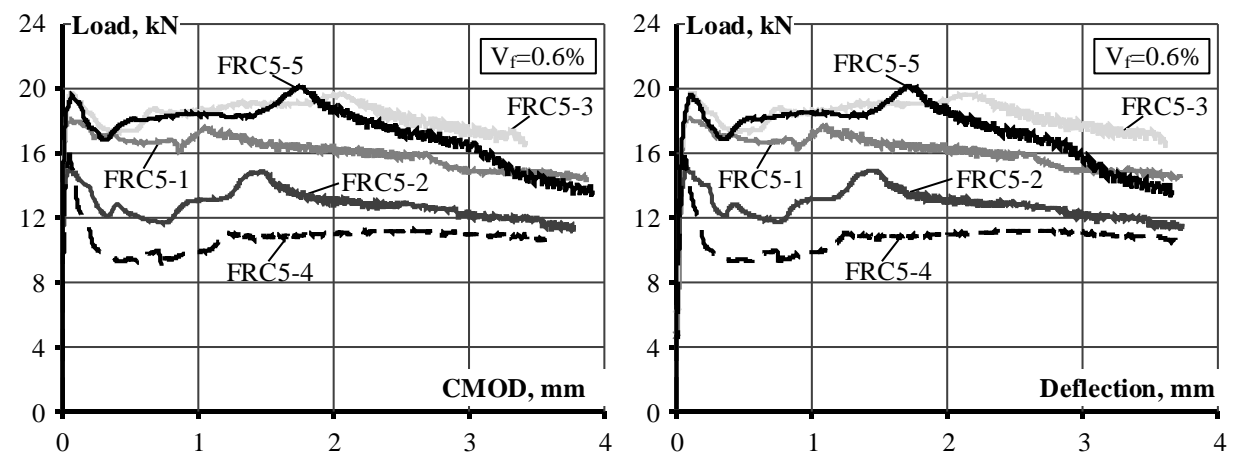

Fig. 2.10. Experimentally obtained load-CMOD and load-deflection diagrams of three-point loading FRC5 series beams

The load-deflection or load-CMOD response of the SFRC beams under three-point bending could be characterised by three phases. Until the onset of cracking the response is linear. The second phase is triggered by crack formation and propagation. During this phase, the beam reaches its peak load. During the third phase, most of the stress is carried by the steel fibres as crack bridging through the concrete aggregate interlock is negligible. Figures 2.6 and 2.9 illustrates results for FRC1 and FRC4 series beams reinforced with 0.3 and $0.5 \%$ of fibres by volume. All beams presented a deflection softening response under three-point bending.

Figure 2.7 shows three of the five tested FRC2 series beams, which experienced a deflection softening behaviour with a first cracking load higher (from 2 to $10 \%$ ) than the second peak due to fibres bridging action. The remaining two samples on the contrary showed a deflection hardening response with the second peak higher (approximately from 7 to 15\%) than the first peak. On average, as it is seen from FRC3 and FRC5 series beams in Figs. 2.8 and 2.10 the SFRC specimens had approximately a constant (approaching plastic) response, which was neither strictly hardening nor softening in the observed range of deflection or CMOD.

Figures $2.11,2.12,2.13,2.14$ and 2.15 present the experimental load-deflection curves for 22 beams tested under 4 point loading tests. Experimental investigation was performed for series FRC1, FRC2, FRC3, FRC4 and FRC5 according to DAfStb-Richtlinie (2010). 


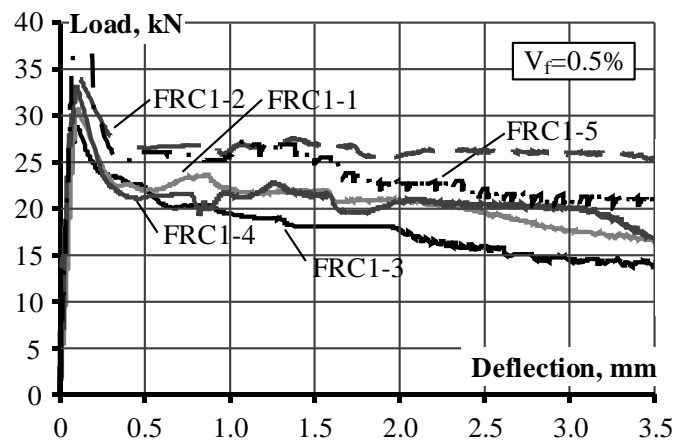

Fig. 2.11. Experimentally obtained load-deflection diagrams of four-point loading FRC1 series beams

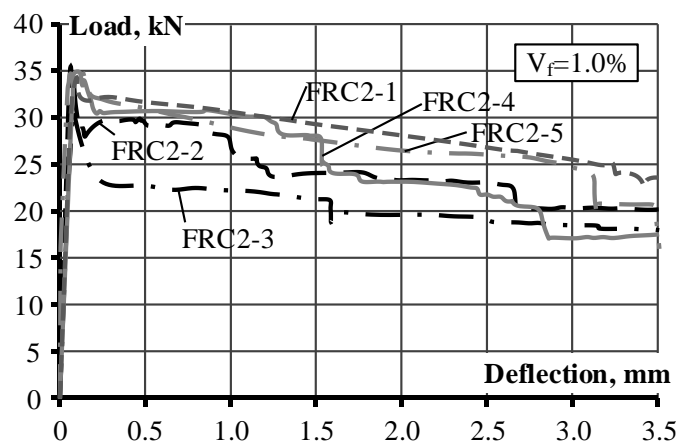

Fig. 2.12. Experimentally obtained load-deflection diagrams of four-point loading FRC2 series beams

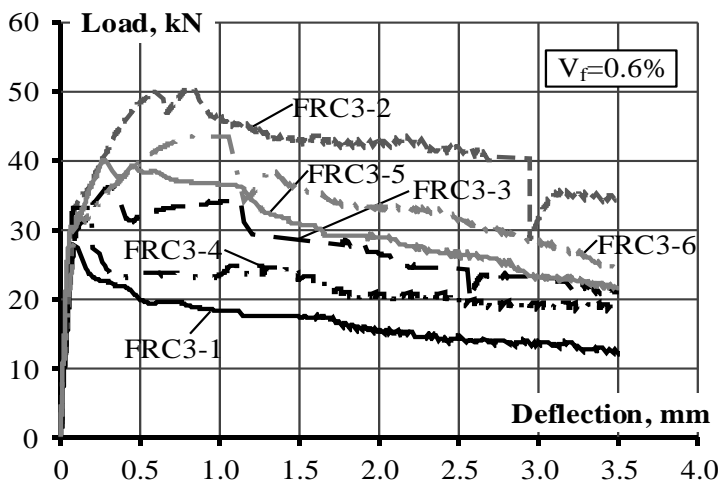

Fig. 2.13. Experimentally obtained load-deflection diagrams of four-point loading FRC3 series beams 


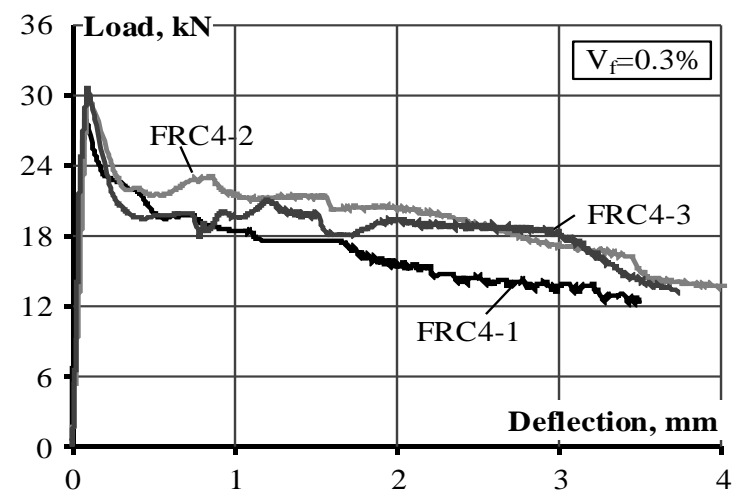

Fig. 2.14. Experimentally obtained load-deflection diagrams of four-point loading FRC4 series beams

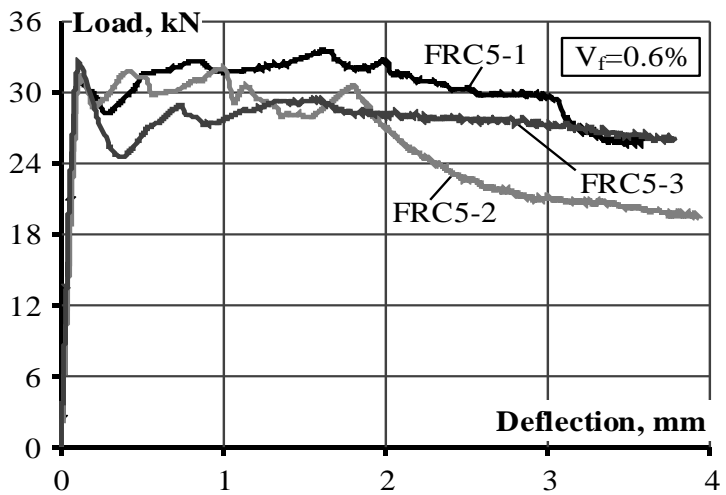

Fig. 2.15. Experimentally obtained load-deflection diagrams of four-point loading FRC5 series beams

A considerable variation in the load-deflection response can be observed for all beams series which is attributed to variations in the fibre distribution and orientation as discussed below. Figures 2.11 and 2.14 show typical deflection softening response for FRC1 and FRC4 series beams. As it can be seen in Fig. 2.12, beams FRC2-1 and FRC2-3 exhibit a hardening response up to a displacement of around $0.5 \mathrm{~mm}$ unlike the other beams, which exhibit a softening response. In beam series FRC3 (Fig. 2.13), beams FRC3-2, FRC3-3, FRC3-5 and FRC3-6 also exhibited a "pseudo" hardening response whereas the remaining two beams exhibit a tension softening response. On the other hand, beam FRC3-3 has exhibited an uncharacteristic response, compared with the other beams. In order to investigate further, the beam was loaded to a complete failure. There was a relatively 
higher number of fibres present in the crack formation section, which accounts for the unrealistic response of this test specimen (see Fig. 2.16f). Beam series FRC5 (Fig. 2.15) have shown approximately a constant response for beams FRC5-1 and FRC5-3 up to a displacement of around $1.5 \mathrm{~mm}$, however beam FRC5-2 has shown tension softening response.

Despite the loading differences between the three-point and four-point bending tests, another main modification in geometry of the beams is the notch. The cross-section of the three-point bending test is notched at the mid-span, whereas the four-point bending test specimens are uncut. The introduction of the notch influences the structural behaviour by forcing the localized cracking behaviour at a certain position. In comparison to the un-notched test beams, due to the weakened cross-section deformations are localised at the early stage of loading. The advantage with the four-point un-notched bending test is that it incorporates the effect of variation of the tensile or flexural strength of SFRC, since the first crack can appear at the weakest section. The main disadvantage is that it is impossible to predict the position of the crack, which makes does not allow to measure the crack opening deflections. On the other hand, in the four-point bending tests, especially for higher fibre volume ratios and compressive strengths, several cracks can appear between the two applied loads.

Figures 2.16 and 2.17 show typical crack patterns for the SFRC beams at peak load for beams tested under three- and four-point loading tests. Peak load in the SFRC beams under three-point bending typically resulted in a single crack at the notch location (Figs. 2.16a and 2.16c). However, for some specimens of beam series FRC2, FRC3 and FRC5 additional post-peak load increment resulted in the development of additional cracks, as shown in Fig. 2.16b. The experimental results have also shown that for some SFRC specimens multiple cracking occurred prior to reaching the peak load, regardless of beam cross-sectional reduction at the notch (i.e., point of maximum moment). While the load-CMOD response for SFRC (Fig. 2.10, beams FRC5-1 and FRC5-2) did not clearly indicate a deflection hardening or softening SFRC material, a multiple cracking response was observed right after the peak load was reached (Fig. 2.16b). In some beams multiple cracking can be observed above the notch and/or on both sides of the notch, indicating that notch opening comprises only a portion of the beam deformations (Figs 2.16d and 2.16e). However, all deformations present research were captured by a LVDT gauge located at the notch, as all cracks for tested beams appeared within the gauge length. It is also important to note that, as multiple cracks form, CMOD measurements do not capture a true single crack opening response, which is important for serviceability limit state design. 


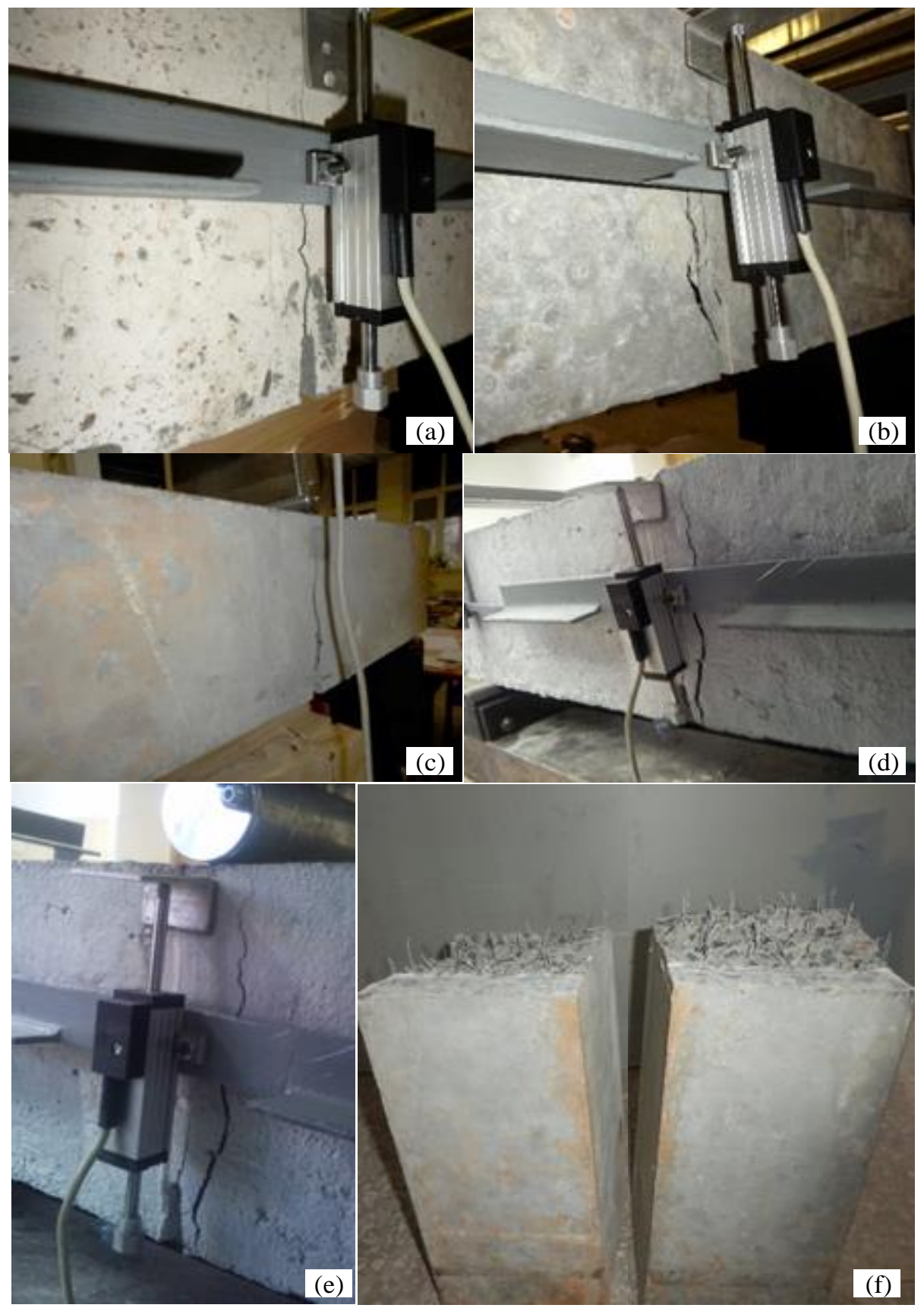

Fig. 2.16. Typical cracking at peak load for three-point bending beams 


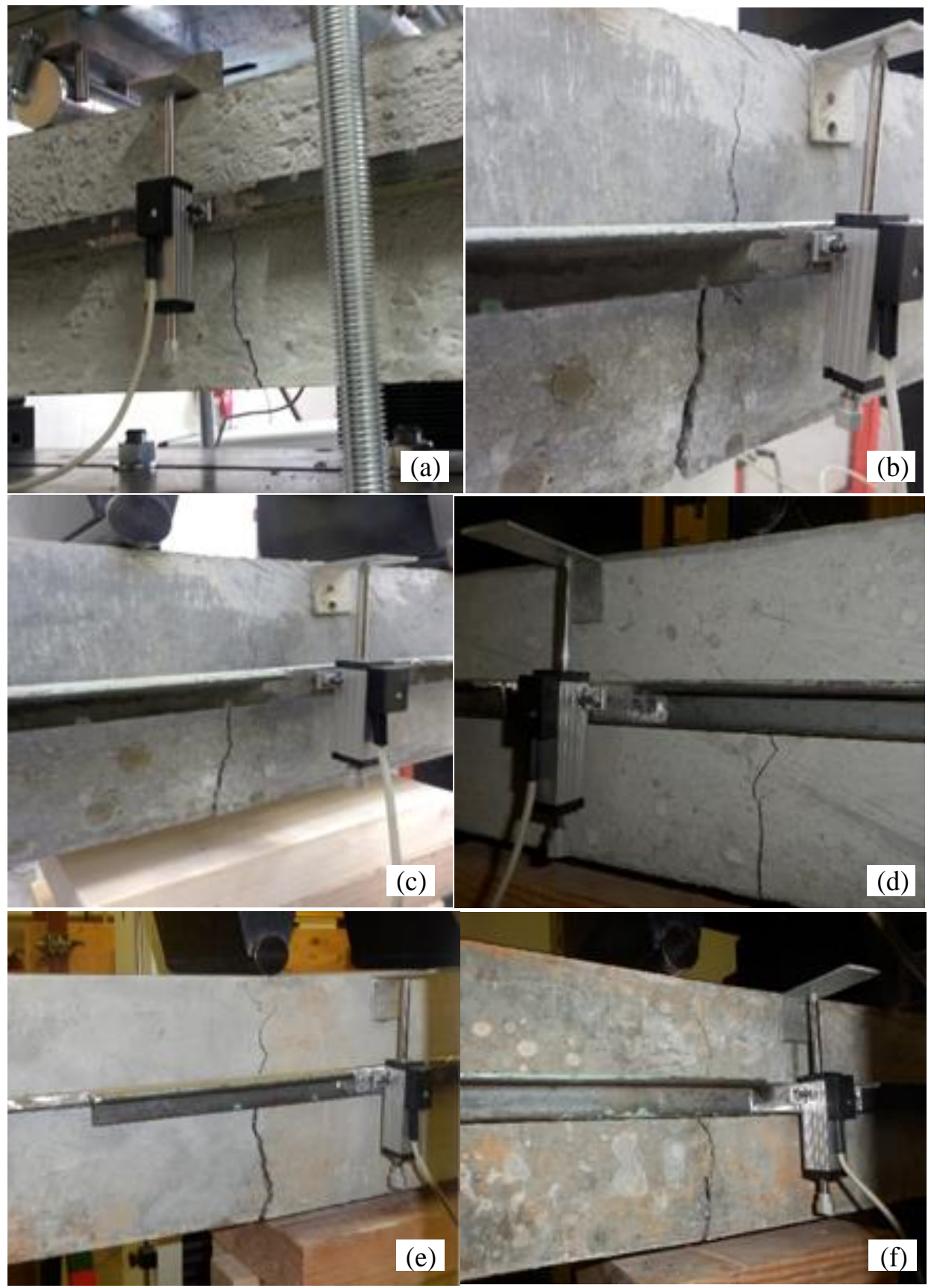

Fig. 2.17. Typical cracking at peak load for four-point bending beams 
Figure 2.17 shows typical SFRC beams with a single main crack in the constant moment region at peak load. However, in some of the tested SFRC beams small secondary cracks were observed near peak loading (Fig. 2.17d). Majority of the tested SFRC specimens under four-point bending have exhibited a single crack propagating on the limit of the constant moment region, i.e. just below the loading application point (Figs $2.17 \mathrm{e}$ and 2.17f). Figure $2.17 \mathrm{c}$ shows an example of a crack just outside of the constant moment region. The varying homogeneity of the beams likely causes the varying crack behaviours. Therefore, the deformation of the specimen subjected to four-point loading is dependent on the position of the crack and sometimes the measured deflection does not represent the exact deformation of the beam.

For the notched three-point bending, the stress field according to flexural beam theory should result in a single crack extending from the notch towards the loading point. However, the actual crack patterns obtained from three-point bending test according to EN14651 (2007) procedure included multiple cracking. Multiple cracking shows that the strain and stress fields at the notched mid-span section are much more complex than assumed in the guidelines. Both the notch and the point load at the mid-span result in a stress concentration. The stress field at the weakened cross-section is disturbed and far from being in agreement with traditional beam theory.

Therefore, in the case of the development of multiple cracks initiated at the notch and progressing further in the beam, the characteristics of steel fibre reinforced concrete attained from three-point bending tests are not completely representative for the SFRC. The testing procedure is based on the assumption that due to the applied notch only a single crack would appear and, therefore, the crack opening with corresponding load capacity will be measured. However, when multiple cracks develop from the tip of the notch, the measured CMOD results in the sum of many smaller cracks and, therefore the true crack opening surface is not considered. Consequently, the results would not represent the material characteristics correctly, especially considering the serviceability limit state.

Although the constant moment region of the four-point bending beam theoretically allows the formation of multiple cracking of a deflection hardening material, cracks sometimes developed outside of the constant moment region for the SFRC beams. Cracks forming outside of the constant moment region are influenced not only by bending but also by shear. In some beams cracks were more concentrated in the region under the two loading points and were inclined with a typical mixed shear-flexure crack pattern.

As mentioned in the Chapter 1, the results of three-point and four-point bending beams may vary significantly due to a number of reasons, including details of the specimen preparation and casting method, resulting in fibre distribution 
and orientation as well as testing conditions (e.g. the amount of friction to rotation and translation in the supports).

However, this study with higher fibre contents, was able to obtain very consistent results for beam tests. The comparison of the results of three-point bending test according to EN14651 (2007) and four-point bending test according to DAfStb-Richtlinie (2010) recommendations is presented in Section 2.3.

\subsection{Proposed Technique for Development of the Residual Strength}

Considering steel fibre reinforced concrete as a homogenous material, the postcracking behaviour of SFRC can be described by the stress-crack opening $(\sigma-w)$ relationship, where post-cracking capacity is presented as combination of both concrete and a fibre contribution. However, quantifying the residual stresses of cracked SFRC in tension $\sigma_{f r}$ is an intricate problem. As described in the previous Chapter, there are a number guidelines presenting material models of SFRC in tension. However all of them are based on some empirical coefficients and approximations. The main idea of an inverse analysis is determination of the parameters of a model based on the response of structure securing the same modelling result (at the assumed tolerance) as the initially assumed one. The proposed technique aims at determination of residual stress-crack opening $(\sigma-w)$ relations using experimental measurements of the deflection and CMOD of SFRC beams. For the illustration a model based on three-point loading beam test was chosen as it is possible in a simple way to locate the crack, measure its width and deflection of the specimen. However, it could be easily extended for four-point loading beams implementing digital image correlation (DIC) method for deformation and cracking analysis.

Let us consider the cracked SFRC beam subjected to three-point loading as a mechanism of two rigid bodies interacting at a fictitious hinge (Fig. 2.18). The non-linear hinge framework utilises fracture mechanics to describe the behaviour of a cracked element, whereas the remaining part of the structure is assumed to behave in a linear elastic fashion. It can be assumed that the location of the hinge coincides with the neutral axis position at the crack plane.

According to scheme, shown in Fig. 2.18, assumptions have to be made concerning the fictitious crack surfaces and the crack opening angle:

- elastic part of deflection and crack opening is neglected;

- the crack surfaces remain plane (i.e. the overall angular deformation equals the crack opening angle). 


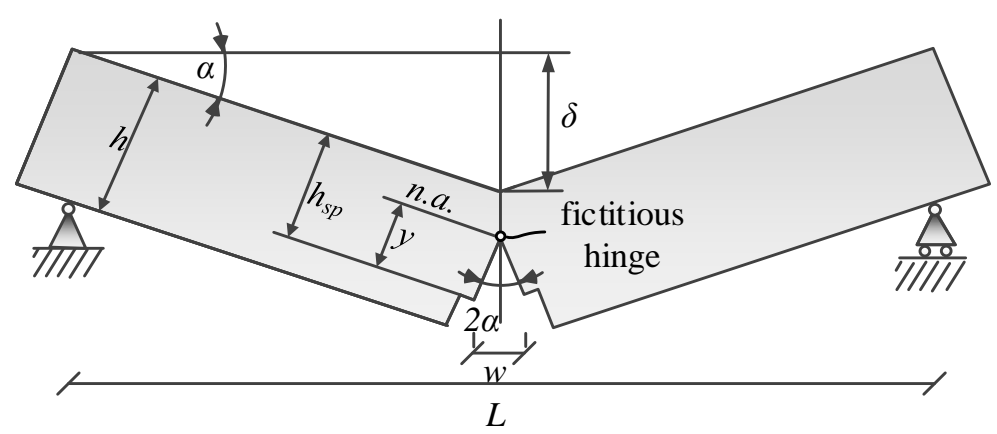

Fig. 2.18. Deformation behaviour of the beam

These approximations allow simple solutions that can be easily adopted in design. Following the above assumptions, for the deformation model shown in Fig. 2.18, the crack-opening angle $\alpha$, deflection $\delta$ and the distance between crack tip and neutral axis $y$ can be geometrically interrelated as follows:

$$
\begin{aligned}
& \operatorname{tg} \alpha=2 \cdot \delta / L ; \\
& \operatorname{tg} \alpha=w / 2 y .
\end{aligned}
$$

From the above equations, location of the neutral axis can be determined:

$$
\frac{2 \cdot \delta}{L}=\frac{w}{2 \cdot y} \Rightarrow y=\frac{w \cdot L}{4 \cdot \delta} .
$$

It is important to note that with increasing loading, the location of the neutral axis changes, moving towards the compressive face of the beam, thus it should be identified for every loading step, considered in analysis (Eq. 2.1). The stress distribution in the cross section also changes. SFRC rapidly loses its resistance in tension due to the propagating crack and only at the very near vicinity of the neutral axis the concrete is not ruptured. The crack is then bridged only by the fibres which transfer the tensile forces across the expanding crack width. Therefore, it is presumed that residual stresses are acting up to neutral axis. With every loading step the propagating crack is divided into small crack intervals, which are assumed to carry constant residual stresses (Fig. 2.19).

Distribution of residual stresses in a cracked section can determined as described below. Assuming small enough constant crack intervals $w_{i}$, e.g. $\Delta w=0.05 \mathrm{~mm}$, an experimental load-crack opening $P-w$ and load-deflection $P-\delta$ diagrams (Fig. 2.20) are divided into $n$ parts, according to the specified crack ranges $w_{i}\left(\right.$ where $\left.w_{i}=0.05 ; 0.10 ; 0.15 ; \ldots ; w_{n}\right)$. 


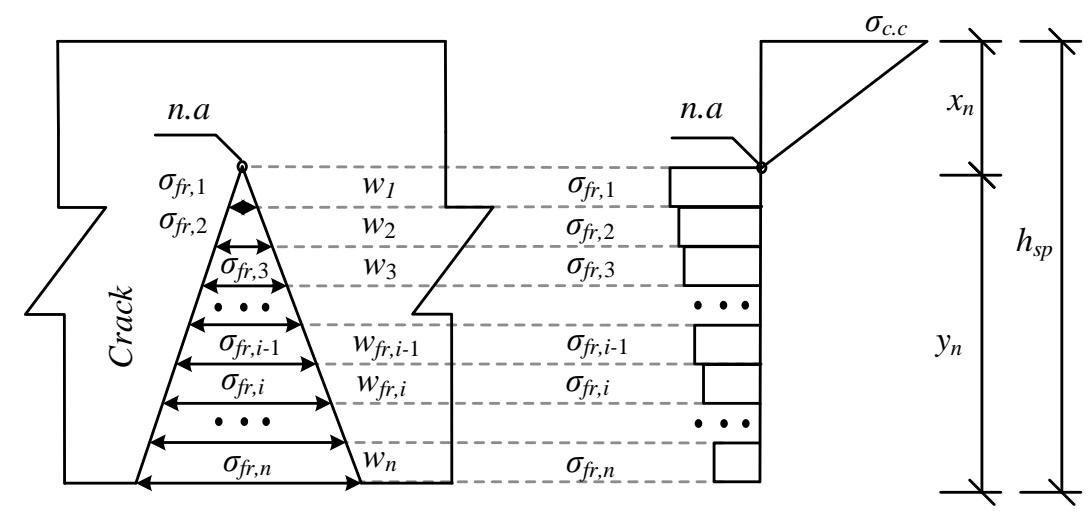

Fig. 2.19. Assumed residual stresses distribution
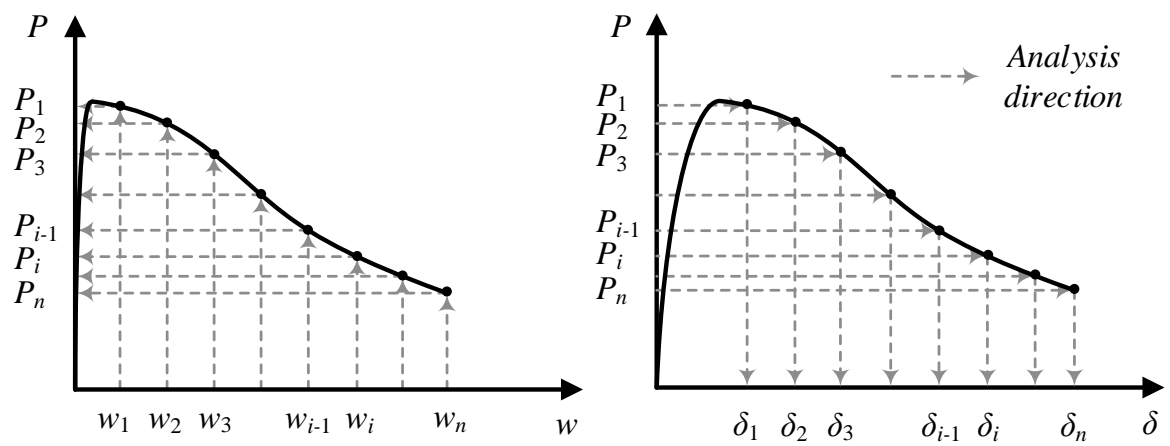

Fig. 2.20. Division of experimental diagrams according to the specified crack width intervals

Let us consider the $i$-th load step. Bending moment equilibrium equation is solved with respect to the point $O$, as shown in Fig. 2.21. The unknown position of the neutral axis is obtained from expression of residual stresses by simultaneously solving equilibrium equations of axial forces and bending moments:

$$
\begin{gathered}
\sigma_{f r, n}=0.5 E\left[\varepsilon_{n}^{2}(\bar{h}-1)-\varepsilon_{c r}^{2}\right]-\sum_{i=2}^{n} \sigma_{f r, i-1}\left(\varepsilon_{i-1}-\varepsilon_{i-2}\right)= \\
\frac{\frac{P_{n} L \varepsilon_{n}^{2}}{2 b y_{n}^{2}}-\frac{2 E}{3}\left[\varepsilon_{n}^{3}(\bar{h}-1)+\varepsilon_{c r}^{3}\right]-\sum_{i=2}^{n} \sigma_{f r, i-1}\left(\varepsilon_{i-1}^{2}-\varepsilon_{i-2}^{2}\right)}{\varepsilon_{n-1}+\varepsilon_{n}} .
\end{gathered}
$$

Residual stresses and, therefore, crack width can be found from equilibrium of axial forces: 


$$
\begin{gathered}
0.5 E\left[(\bar{h}-1)^{2}-\varepsilon_{c r}^{2} y_{n}^{2} / \varepsilon_{n}^{2}\right]-\sum_{i=1}^{n} \sigma_{f r, i}\left(\varepsilon_{i}-\varepsilon_{i-1}\right)=0 ; \\
\bar{h}=h_{s p} / y_{n}, \quad \varepsilon_{c r}=f_{c t} / E, \quad \varepsilon_{n}=w_{n} /\left(2 y_{n}\right), \quad \varepsilon_{0}=\varepsilon_{c r} .
\end{gathered}
$$

In Equations (2.4) and (2.5), $n$ is the loading step under consideration; $\sigma_{r, n}$ is the residual stresses, $\varepsilon_{n}$ is the deformation of element, $w_{n}$ is the crack width, $y_{n}$ is the position of neutral axis, and $P_{n}$ is the load at $n$-th step; $E$ and $f_{c t}$ are the deformation modulus and tensile strength of SFRC; $h_{s p}$ is the depth of the notched section; $L$ and $b$ are the span and the width of specimen, respectively.

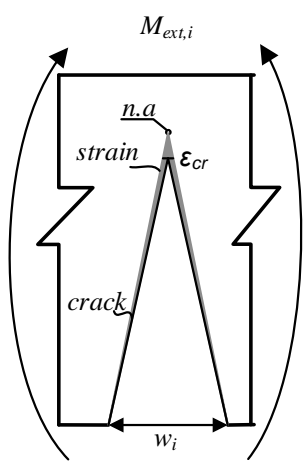

Actual crack

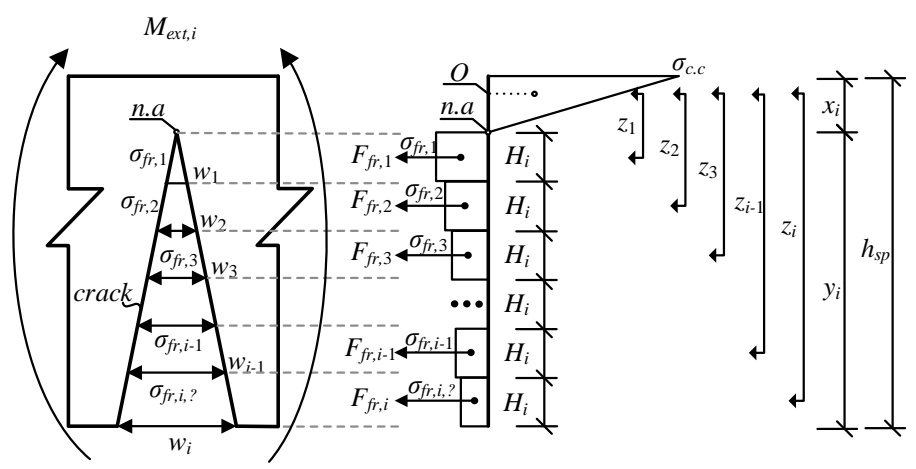

Idealized crack

Residual stress distribution scheme

Fig. 2.21. Principal scheme for residual stresses analysis at i-step

\subsection{Comparative Analysis of the Results}

This Section considers a comparative analysis of the modelled and experimental results. The differences between the standard and proposed constitutive modelling methods and their capacity to predict the flexural behaviour of SFRC elements is described.

\subsubsection{Post-cracking Behaviour}

From the experimental data of three and four-point bending tests, residual stresses were obtained employing procedures described in RILEM TC 162-TDF (2002), Model Code (fib 2013) and DAfStb-Richtlinie (2010). The residual stresses were calculated at specific locations of the SFRC load-deflection curve; $\sigma_{f r}$ is calculated at a mid-span deflection of $0.46 \mathrm{~mm}$ or CMOD of $0.5 \mathrm{~mm} ; \sigma_{f r 4}$ is calculated at a mid-span deflection of $3 \mathrm{~mm}$ or a CMOD of $3.5 \mathrm{~mm}$ (RILEM TC 162-TDF 2002), whereas according to Model Code (fib 2013) $\sigma_{f r 1}$ is defined at the same 
manner described above and $\sigma_{f r 3}$ is calculated at a mid-span deflection of $2.15 \mathrm{~mm}$ or a CMOD of $2.5 \mathrm{~mm}$. Table 2.4. lists the characteristic values of the post-cracking loads $P_{1}, P_{3}$ and $P_{4}$ and residual stresses $\sigma_{f r 1}, \sigma_{f r 3}$ and $\sigma_{f r 4}$ obtained from the three-point bending tests for beam series FRC1, FRC2, FRC3, FRC4 and FRC5.

Table 2.4. Characteristic values of the three-point bending tests

\begin{tabular}{|c|c|c|c|c|c|c|c|}
\hline $\begin{array}{c}\text { Beam } \\
\text { No. }\end{array}$ & Beam & $P_{1}, \mathrm{kN}$ & $P_{3}, \mathrm{kN}$ & $P_{4}, \mathrm{kN}$ & $\begin{array}{c}\sigma_{f r 1}, \\
\text { MPa }\end{array}$ & $\begin{array}{c}\sigma_{f r 3}, \\
\text { MPa }\end{array}$ & $\begin{array}{c}\sigma_{f r 4}, \\
\text { MPa }\end{array}$ \\
\hline 1 & FRC1-1 & 11.08 & 9.95 & 8.44 & 1.60 & 1.18 & 1.00 \\
\hline 2 & FRC1-2 & 7.89 & 7.70 & 7.44 & 1.14 & 0.91 & 0.88 \\
\hline 3 & FRC1-3 & 10.49 & 10.55 & 9.00 & 1.51 & 1.25 & 1.07 \\
\hline 4 & FRC1-4 & 7.54 & 6.88 & 7.18 & 1.09 & 0.81 & 0.85 \\
\hline 5 & FRC1-5 & 7.48 & 7.23 & 7.75 & 1.08 & 0.86 & 0.92 \\
\hline 6 & FRC2-1 & 16.64 & 15.26 & 14.17 & 2.40 & 1.81 & 1.68 \\
\hline 7 & FRC2-2 & 18.33 & 16.17 & 14.35 & 2.64 & 1.91 & 1.70 \\
\hline 8 & FRC2-3 & 8.95 & 10.08 & 9.53 & 1.29 & 1.19 & 1.13 \\
\hline 9 & FRC2-4 & 16.65 & 13.89 & 12.19 & 2.40 & 1.64 & 1.44 \\
\hline 10 & FRC2-5 & 15.84 & 15.19 & 13.62 & 2.28 & 1.80 & 1.61 \\
\hline 11 & FRC3-1 & 15.29 & 13.83 & 12.33 & 2.20 & 1.64 & 1.46 \\
\hline 12 & FRC3-2 & 23.13 & 16.9 & 15.71 & 3.33 & 2.00 & 1.86 \\
\hline 13 & FRC3-3 & 19.71 & 13.81 & 11.77 & 2.84 & 1.64 & 1.39 \\
\hline 14 & FRC3-4 & 27.04 & 16.86 & 15.35 & 3.89 & 2.00 & 1.82 \\
\hline 15 & FRC3-5 & 19.59 & 11.22 & 9.29 & 2.82 & 1.33 & 1.10 \\
\hline 16 & FRC3-6 & 17.12 & 12.25 & 10.84 & 2.47 & 1.45 & 1.28 \\
\hline 17 & FRC4-1 & 7.93 & 6.48 & 5.58 & 1.14 & 0.77 & 0.66 \\
\hline 18 & FRC4-2 & 6.40 & 4.02 & 3.51 & 0.92 & 0.48 & 0.42 \\
\hline 19 & FRC4-3 & 6.72 & 6.59 & 5.66 & 0.97 & 0.78 & 0.67 \\
\hline 20 & FRC4-4 & 4.52 & 2.63 & 2.48 & 0.65 & 0.31 & 0.29 \\
\hline 21 & FRC4-5 & 7.92 & 5.59 & 5.10 & 1.14 & 0.66 & 0.60 \\
\hline 22 & FRC5-1 & 16.85 & 16.04 & 14.65 & 2.43 & 1.90 & 1.73 \\
\hline 23 & FRC5-2 & 12.41 & 12.67 & 11.67 & 1.79 & 1.50 & 1.38 \\
\hline 24 & FRC5-3 & 17.40 & 18.57 & 17.33 & 2.51 & 2.20 & 2.05 \\
\hline 25 & FRC5-4 & 9.43 & 12.59 & 10.84 & 1.36 & 1.49 & 1.28 \\
\hline 26 & FRC5-5 & 17.98 & 17.44 & 14.00 & 2.59 & 2.06 & 1.66 \\
\hline
\end{tabular}


Table 2.5 presents the characteristic values of the post-cracking parameters obtained from the four-point bending tests for series FRC1, FRC2, FRC3, FRC4 and FRC5 according to DAfStb-Richtlinie (2010). The residual stresses were calculated at different locations of the SFRC load-deflection curve; $\sigma_{f r 1}$ is defined at a mid-span deflection of $0.46 \mathrm{~mm} ; \sigma_{f r 4}$ is calculated at a mid-span deflection of $3 \mathrm{~mm}$ or a CMOD of $3.5 \mathrm{~mm}$.

Table 2.5. Characteristic values of the four-point bending tests

\begin{tabular}{|c|c|c|c|c|c|}
\hline Beam No. & Beam & $\boldsymbol{P}_{\mathbf{1}}, \mathbf{k N}$ & $\boldsymbol{P}_{\mathbf{4}}, \mathbf{k N}$ & $\sigma_{\boldsymbol{f r} \mathbf{r}}, \mathbf{M P a}$ & $\boldsymbol{\sigma}_{\boldsymbol{f r} \mathbf{4}}, \mathbf{M P a}$ \\
\hline 1 & FRC1-1 & 22.74 & 16.97 & 1.62 & 0.75 \\
\hline 2 & FRC1-2 & 26.01 & 25.08 & 1.85 & 1.11 \\
\hline 3 & FRC1-3 & 22.6 & 14.33 & 1.61 & 0.64 \\
\hline 4 & FRC1-4 & 21.14 & 16.91 & 1.50 & 0.75 \\
\hline 5 & FRC1-5 & 25.82 & 21.02 & 1.84 & 0.93 \\
\hline 6 & FRC2-1 & 39.98 & 12.43 & 2.84 & 0.55 \\
\hline 7 & FRC2-2 & 32.08 & 24.09 & 2.28 & 1.07 \\
\hline 8 & FRC2-3 & 29.89 & 20.06 & 2.13 & 0.89 \\
\hline 9 & FRC2-4 & 22.57 & 17.55 & 1.60 & 0.78 \\
\hline 10 & FRC2-5 & 30.43 & 17.5 & 2.16 & 0.78 \\
\hline 11 & FRC3-1 & 19.94 & 12.43 & 1.42 & 0.55 \\
\hline 12 & FRC3-2 & 48.69 & 35.17 & 3.46 & 1.56 \\
\hline 13 & FRC3-3 & 31.95 & 21.00 & 2.27 & 0.93 \\
\hline 14 & FRC3-4 & 23.71 & 19.15 & 1.69 & 0.85 \\
\hline 15 & FRC3-5 & 38.43 & 21.43 & 2.73 & 0.95 \\
\hline 16 & FRC3-6 & 39.96 & 24.26 & 2.84 & 1.08 \\
\hline 17 & FRC4-1 & 20.00 & 12.50 & 1.42 & 0.56 \\
\hline 18 & FRC4-2 & 21.45 & 15.20 & 1.53 & 0.68 \\
\hline 19 & FRC4-3 & 19.64 & 14.25 & 1.40 & 0.63 \\
\hline 20 & FRC5-1 & 31.52 & 25.81 & 2.24 & 1.15 \\
\hline 21 & FRC5-2 & 31.27 & 20.21 & 2.22 & 0.90 \\
\hline 22 & FRC5-3 & 26.43 & 26.38 & 1.88 & 1.17 \\
\hline & & & & & \\
\hline
\end{tabular}


The average values of the post-peak parameters obtained from the three-point and four-point bending tests for beam series FRC1, FRC2, FRC3, FRC4 and FRC5 are presented in Table 2.6. Additionally, empirical residual strength values for each series of beams calculated by the method proposed by Naaman (2003b) are presented.

Table 2.6. Comparison of average results

\begin{tabular}{|c|c|c|c|c|c|c|c|}
\hline \multirow{2}{*}{$\begin{array}{l}\text { Beam } \\
\text { series }\end{array}$} & \multicolumn{2}{|c|}{ Rilem } & \multicolumn{2}{|c|}{ Model Code 2010} & \multicolumn{2}{|c|}{ DAfStb-Richtlinie } & \multirow{2}{*}{$\frac{\text { Naaman }}{\sigma_{f r}, \mathrm{MPa}}$} \\
\hline & $\begin{array}{c}\sigma_{f r 1}, \\
\text { MPa }\end{array}$ & $\begin{array}{c}\sigma_{f r 4}, \\
\text { MPa }\end{array}$ & $\begin{array}{c}\sigma_{f r 1}\left(f_{F t s}\right), \\
\mathbf{M P a}\end{array}$ & $\begin{array}{c}\sigma_{f r 3}\left(f_{F t u}\right) \\
\mathbf{M P a}\end{array}$ & $\begin{array}{c}\sigma_{f r 1}, \\
\text { MPa }\end{array}$ & $\begin{array}{c}\sigma_{f r 4}, \\
\text { MPa }\end{array}$ & \\
\hline FRC1 & 1.28 & 0.94 & 1.28 & 0.78 & 1.68 & 0.81 & 0.60 \\
\hline FRC2 & 2.20 & 1.51 & 2.20 & 1.28 & 2.20 & 0.83 & 1.08 \\
\hline FRC3 & 2.93 & 1.49 & 2.93 & 1.06 & 2.40 & 0.99 & 0.80 \\
\hline FRC4 & 0.96 & 0.53 & 0.96 & 0.50 & 1.45 & 0.62 & 0.41 \\
\hline FRC5 & 2.13 & 1.62 & 2.13 & 1.53 & 2.11 & 1.07 & 0.80 \\
\hline
\end{tabular}

From the tables presented above it can be observed that the load versus displacement/deflection results obtained by different methods but for the same series of beams vary quite a lot. Comparing the stress versus crack width or strain results of these methods indicates the classification of certain FRC materials may depend on the selected test method. Table 2.6 shows that all test methods (except empirical result proposed by Naaman) confirm that the investigated SFRC had a deflection softening response, whereas, various responses were found for the studied SFRC. Moreover, it should be noted that for beam series with lower volume of fibres, the residual strength values representing the behaviour of the beam at serviceability limit state differs up to $50 \%$. It is mainly influenced by the casting as well as the loading conditions of the test and, therefore, deformations of beam. The residual strength is very important for assessment of the fibre effect in the presence of bar reinforcement as the behaviour of such elements is characterized by the increased number of relatively smaller cracks. The disagreement between the discussed methods evidences the complexity of the residual strength issue that needs to be treated thoroughly.

\subsubsection{Determination of the $\sigma-w$ Law by Inverse Analysis}

Employing the experimental data of the bending tests described in Section 2.1 and the inverse technique discussed in Section 2.2 post-cracking behaviour of SFRC in tension is modelled. To illustrate the capability of inverse technique, attained 
$\sigma-w$ curves for the tested beams series FRC1 and FRC2, with fibre content of 0.5 and $1.0 \%$ by volume, respectively, are presented in Fig. 2.22.
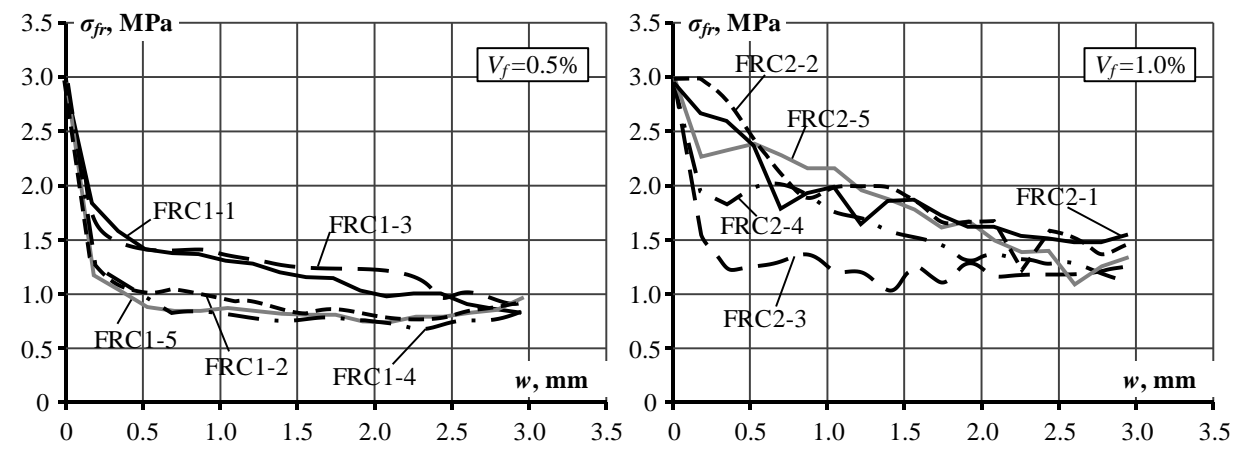

Fig. 2.22. Determined residual stress-crack opening relationships

The results obtained by the proposed inverse technique are compared with the post-cracking behaviour, defined by linear $\sigma$ - $w$ curve defined according to Model Code 2010 (fib 2013) recommendations. The results for the few randomly selected specimens for series FRC1 and FRC2 beams subjected to three-point bending are shown in Figs. 2.23 and 2.24, respectively. It should be noted that the residual stress-crack opening relationships derived by Model Code 2010 (fib 2013) technique are relevant only for specific loading type and size of the specimens. Obtained results are defined by linear curve and are limited up to some deflection or crack opening value. The inverse technique, proposed by the author, can be extensively used for the determination of the residual stresses at each loading step resulting in full post-cracking behaviour diagram of SFRC in tension.
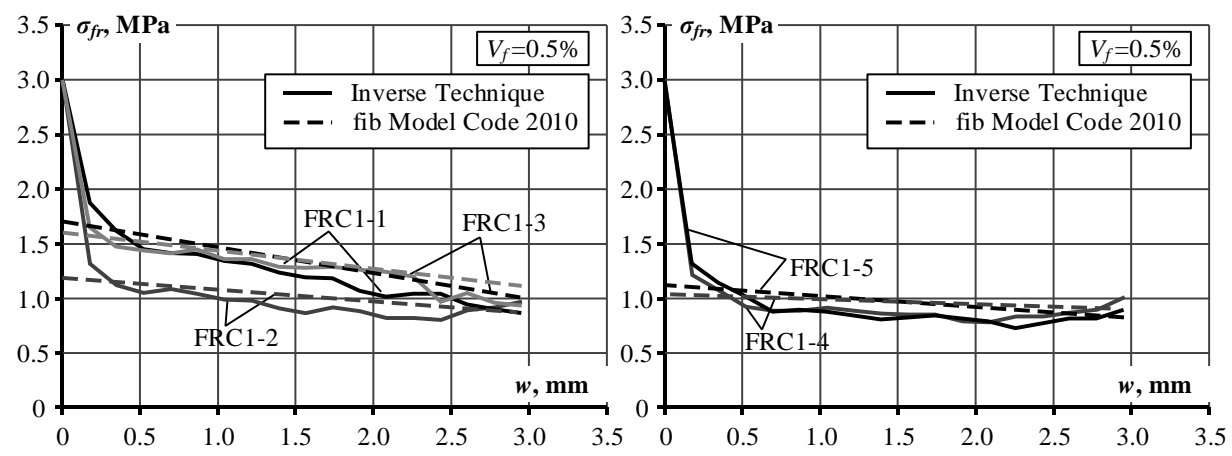

Fig. 2.23. Comparison of residual stress-crack opening relationships for beams FRC1 

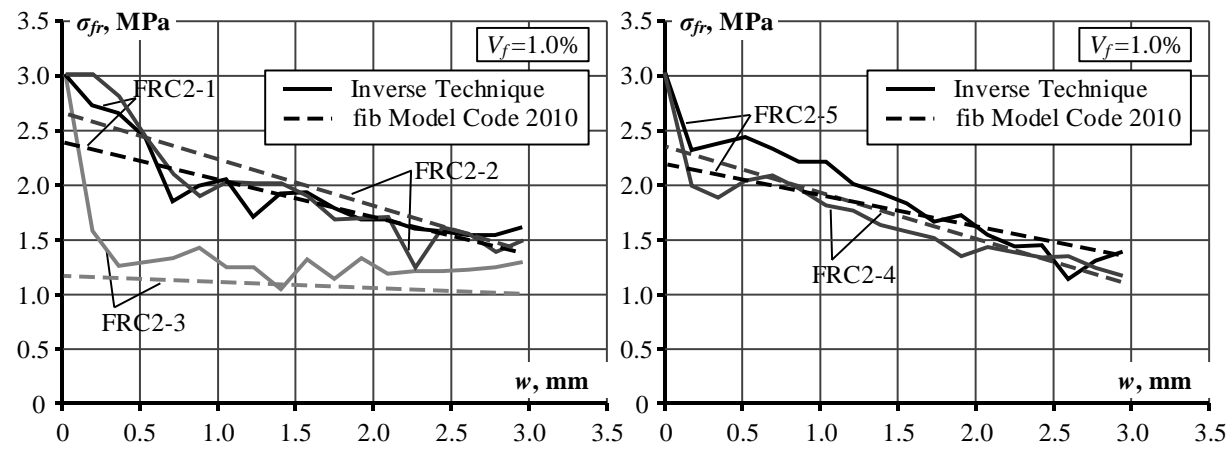

Fig. 2.24. Comparison of residual stress-crack opening relationships for beams FRC2

\subsection{Numerical Modelling}

\subsubsection{Input Parameters}

This Section serves to introduce the finite element (FE) model used for analysis of constitutive modelling results, discussed in Subsection 2.3.1. In order to model the beams there have been mainly three categories of parameters which input have been considered important in nonlinear finite element analysis software ATENA, see Fig. 2.25. Each category, representing a number of different input values, curves or models, will be described further below.

To simulate the beams, a 2D FE model was developed. For the simplicity and reduction of computational time, one half of the beam was modelled with symmetry. It was done to the three-point loading test beams using the symmetry of the transversal central plane (Fig. 2.26). By reducing the size of the model, associated boundary conditions had to be introduced according to basic mechanics. Another tweaking of the geometry was to add steel plates at supports and loading point to distribute the load and avoid local stress peaks, where roller bearings were used in reality. The reinforcement bar for full scale beam was modelled as a straight bar without the bends that were in the real beams.

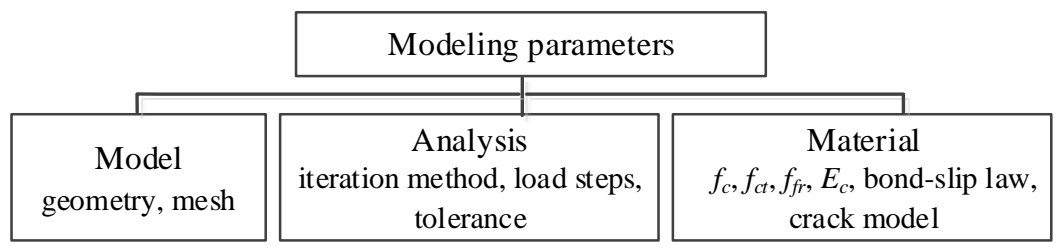

Fig. 2.25. Modelling parameters 
During the thesis process different mesh sizes were used. A coarser mesh was applied at the beginning, which allowed shorter running time for the analysis. However, for the final model the mesh size was chosen to be $3 \mathrm{~cm}$ elements in order to picture the results more accurately and with higher definition. For the finite element model plane quadrilateral $2 \mathrm{D}$ elements were used. These are isoparametric elements integrated by Gauss integration at 4 or 9 integration points for the case of bilinear or bi-quadratic interpolation, i.e. for elements with 4 or 5 and more element nodes, respectively.
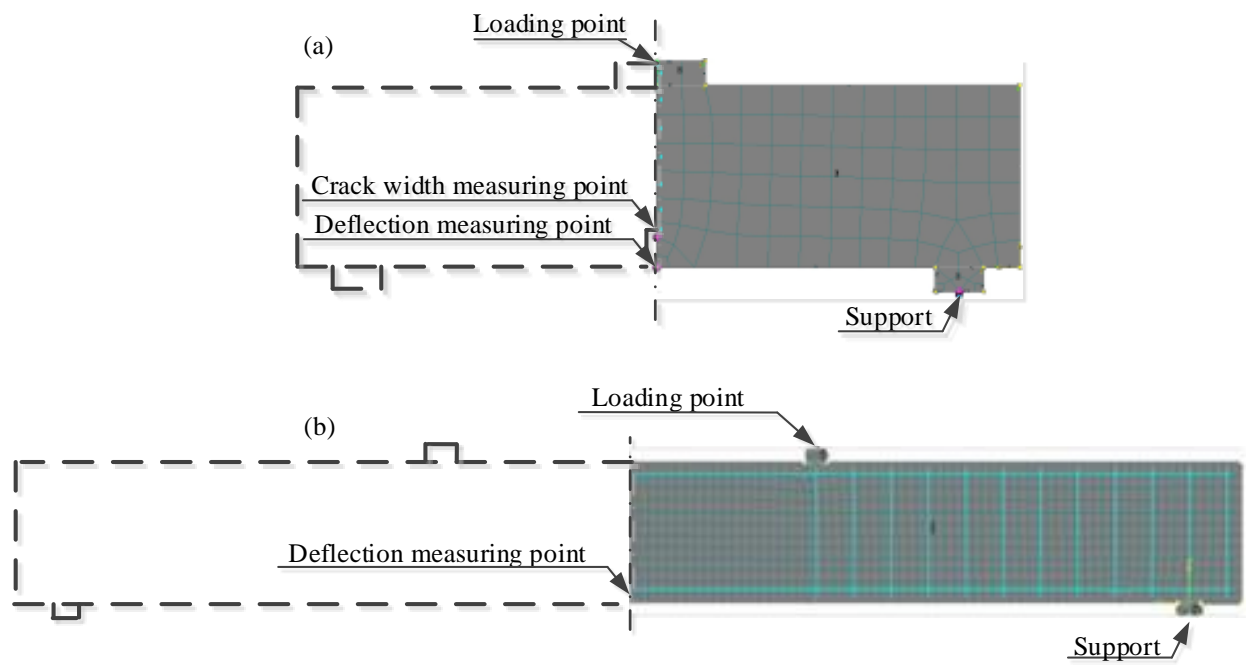

Fig. 2.26. Finite element modelling schemes for three-point loading standard (a) and full scale (b) beams

To define the non-linear bond behaviour in full scale SFRC beams with conventional reinforcement, a bond-slip relationship between the reinforcement bar and the concrete developed by CEB-FIP model code 1990 was used. In this model the law is generated based on the concrete compressive strength, reinforcement diameter and reinforcement type.

The main parameters that influence the load-deflection response of a beam is the constitutive model of the material. For compressive behaviour up to the peak stress a relationship described in CEB-FIP Model Code 1990 is used, while the post-peak softening law in compression is linearly descending. More important and having greater influence on the behaviour of the modelling results is the material model of tensile SFRC. The behaviour of concrete in tension without cracks is assumed as linear elastic. For the post-cracking behaviour in the FEM, stress- 
crack width $(\sigma-w)$ or stress-strain $(\sigma-\varepsilon)$ relationships obtained by the proposed inverse technique, RILEM TC 162-TDF, Model Code 2010, DAfStb-Richtlinie and Naaman methods were implemented as material law of SFRC in tension (Fig. 2.27). Derived residual stress, crack width and strain values are described by so called "softening" and fracture energy parameters and are used as input data for tensile concrete.

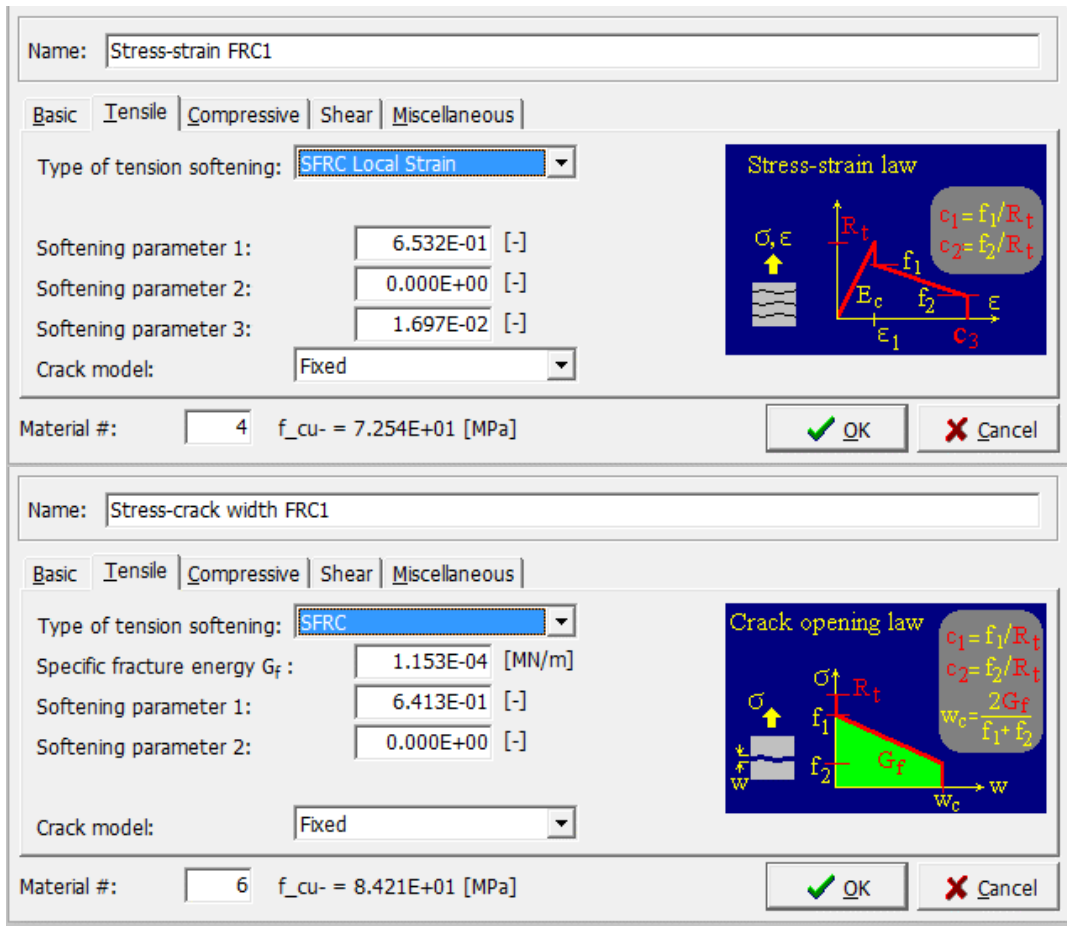

Fig. 2.27. Modelling concrete characteristics

In order to obtain results from the model the analysis procedure have to be adjusted to the type of loading situation. Step size as well as convergence norm need to be considered. The total load value is considered to give results comparable to the full range of the experimental results. Step size was chosen to fulfil convergence conditions.

The iterative process used to solve the equations was the Newton-Raphson method. It uses the stiffness of the structure to find the solution and by updating the stiffness matrix in each iteration, it normally reaches convergence after just a few iterations. If convergence was not reach within 40 iterations the analysis was terminated. 


\subsubsection{Finite Element Analysis Results}

The results from the FE modelling are presented as plots of the load-CMOD relation. A comparison of the experimental and predicted load displacement responses was done using the residual strength responses obtained from four methods: the proposed inverse technique, RILEM TC 162-TDF, Model Code 2010, DAfStbRichtlinie guidelines and Naaman empirical relationship.

The linear stress-crack width relationship according to Model Code 2010 and trilinear stress-strain relationships derived by RILEM TC 162-TDF and DAfStbRichtlinie were adopted for the FE analysis as an input material models. A multilinear response was employed to represent material model obtained by proposed inverse technique, while a constant value of residual strength according to Naaman was used for the simulation. The load-CMOD responses obtained for the three-point loading beams of series FRC1 and FRC2 are presented in Figs. 2.28, 2.29 and 2.30. Only few of the beams of both series are shown.

As it can be seen from the figures presented below, errors were obtained while modelling the peak part of the load-CMOD relationship. This issue seems to be related with the abilities of the FE software. However, for the residual strength analysis the most important is the post-peak part of the curve. Therefore, the horizontal parts of load-CMOD curves, representing the residual strengths, are in a comparable agreement. For the beams presented in Figs. 2.28, 2.29 and 2.30 it can be observed, that the best agreement is achieved employing residual strength obtained by proposed technique, whereas residual strength derived by RILEM TC 162-TDF and Model Code 2010 guidelines in most cases overestimate the stiffness of the three-point loading beams. On the other hand the residual strength calculated by DAfStb-Richtlinie guidelines and Naaman empirical relationship underestimates the stiffness of the post-cracking behaviour.

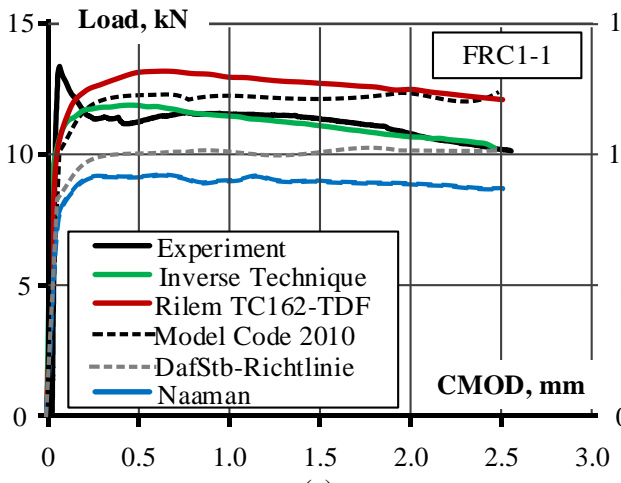

(a)

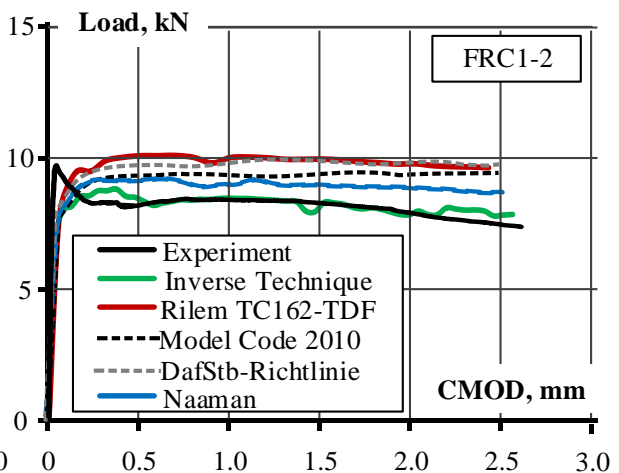

(b)

Fig. 2.28. Comparison of experimental and calculated load-CMOD curves for the experimental three-point loading beams (a) FRC1-1 and (b) FRC1-2 


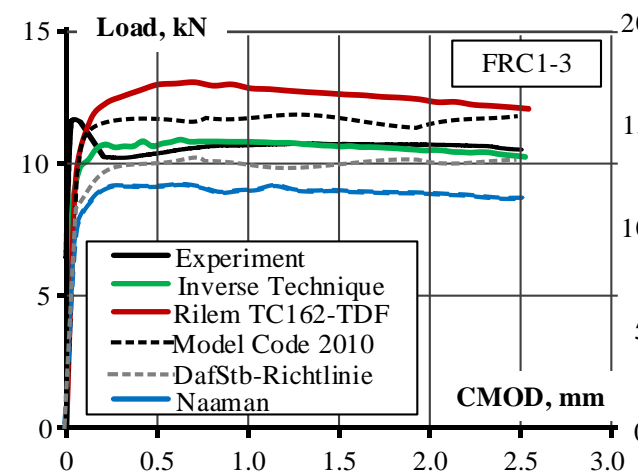

(a)

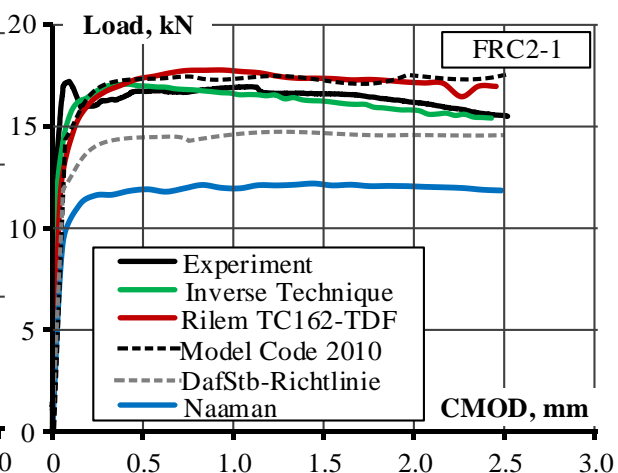

(b)

Fig. 2.29. Comparison of experimental and calculated load-CMOD curves for the experimental three-point loading beams (a) FRC1-3 and (b) FRC2-1

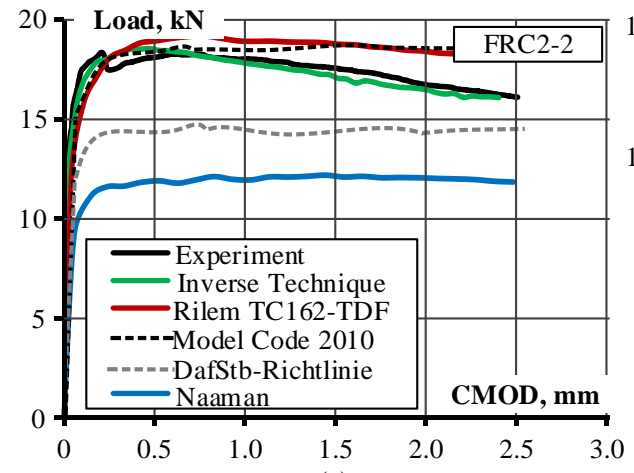

(a)

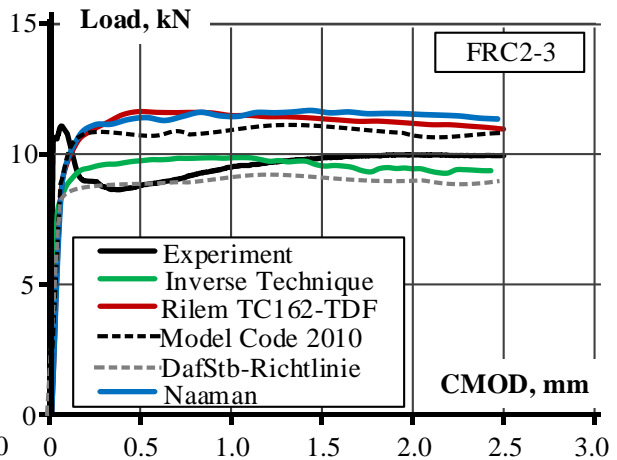

(b)

Fig. 2.30. Comparison of experimental and calculated load-CMOD curves for the experimental three-point loading beams (a) FRC2-2 and (b) FRC2-3

Residual strengths of post-cracking SFRC determined from standard bending tests have been used to simulate the structural response of SFRC beams with bar reinforcement. Two full-scale beams with a span of $3000 \mathrm{~mm}$, with a nominal length of $3280 \mathrm{~mm}$ were analysed. The beams had the same nominal cross-section parameters, resulting in the depth of $300 \mathrm{~mm}$ and width of $280 \mathrm{~mm}$ (Fig. 2.31). The beams were reinforced with three $10 \mathrm{~mm}$ bars in the tensile zone that provides the reinforcement ratio of $0.3 \%$. Other characteristics of full scale beams are presented in Table 2.7 and Fig. 2.31. The beams were reinforced with $23.5 \mathrm{~kg} / \mathrm{m}^{3}$ and $47.1 \mathrm{~kg} / \mathrm{m}^{3}$ of hooked-ended steel fibres, resulting in 0.5 and $1.0 \%$ of fibres by volume. Main characteristics of beam experimental loading and measurement conditions are presented by Gribniak et al. 2012. 
Table 2.7. Main characteristics of the full scale beams

\begin{tabular}{|c|c|c|c|c|c|c|c|c|}
\hline \multirow{2}{*}{ Beam } & $\boldsymbol{A}_{\boldsymbol{s} 1}$ & $\boldsymbol{A}_{\boldsymbol{s} 2}$ & $\boldsymbol{\rho}_{\boldsymbol{l}}$ & $\boldsymbol{V}_{\boldsymbol{f b}}$ & $\boldsymbol{f}_{\boldsymbol{c}}$ & $\boldsymbol{f}_{\boldsymbol{y}}$ & $\boldsymbol{E}_{\boldsymbol{s}}$ & $\boldsymbol{E}_{\boldsymbol{c}}$ \\
\cline { 2 - 9 } & \multicolumn{2}{|c|}{$\mathbf{m m}^{\mathbf{2}}$} & \multicolumn{2}{|c}{$\boldsymbol{\%}$} & \multicolumn{4}{c|}{ MPa } \\
\hline S3-1-F05 & 235.4 & 55.88 & 0.30 & 0.5 & 55.62 & 559.9 & 203000 & 36516 \\
\hline S3-1-F10 & 235.4 & 55.88 & 0.30 & 1.0 & 47.95 & 559.9 & 203000 & 34984 \\
\hline
\end{tabular}

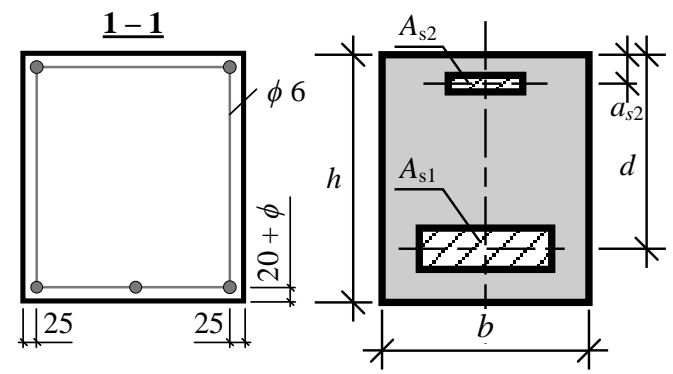

Fig. 2.31. Cross-section scheme of the full-scale beams

In order to avoid the finite element size sensitivity effect, which is mainly attributed to the application of the stress-strain relationship in the FE modelling, only the stress-crack width relationships were employed in the analysis. Linear residual stress relationships defined by Model Code 2010 and Naaman methods as well as the proposed inverse technique were used in modelling. The comparison of the calculated and experimental moment-curvature relationships of the fullscale SFRC beams with bar reinforcement is shown in Figs. 2.32 and 2.33.

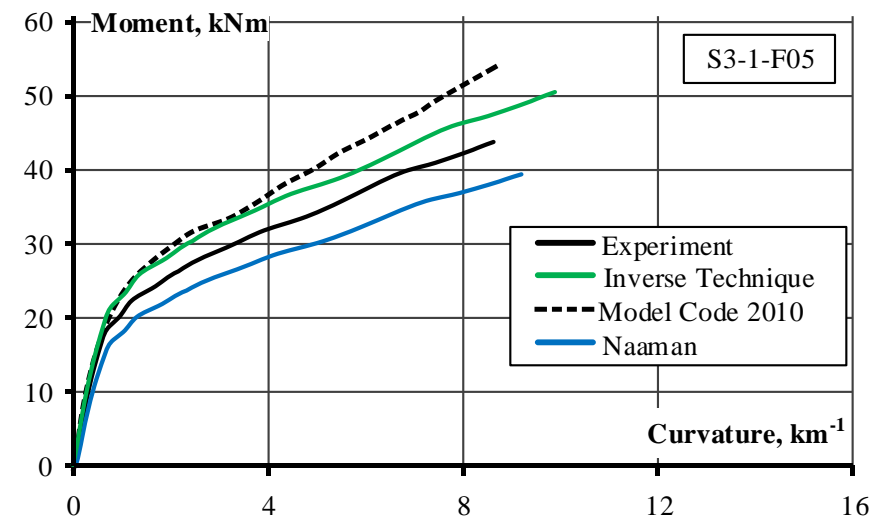

Fig. 2.32. Comparison of experimental and calculated moment-curvature relationships for the experimental full scale beam S3-1-F05 


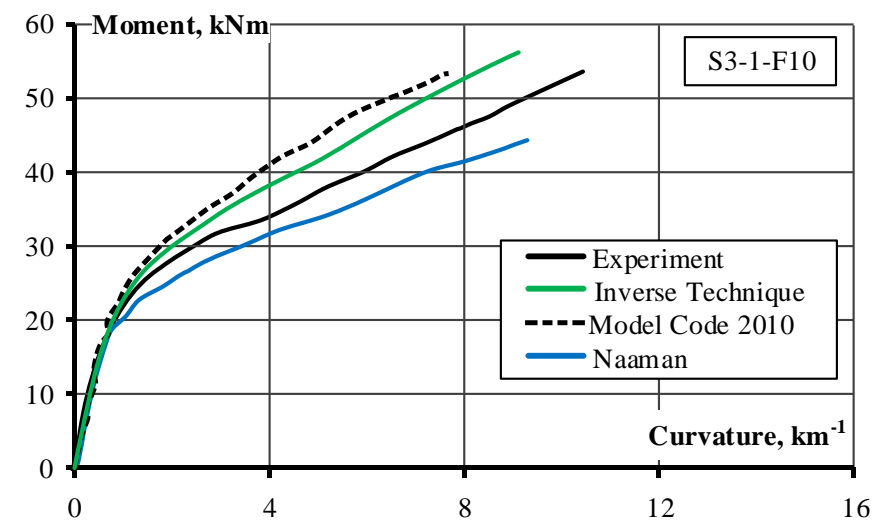

Fig. 2.33. Comparison of experimental and calculated moment-curvature relationships for the experimental full scale beam S3-1-F10

It is seen that for both S3-1-F05 and S3-1-F10 beams curvature of the beams is overestimated using residual strength defined by the Naaman method, while application of the residual strength proposed by inverse technique and Model Code 2010 results in stiffer behaviour of the beams.

\subsection{Conclusions of Chapter 2}

The main conclusions of this Chapter can be drawn:

1. Experimental results of standard flexural SFRC elements subjected to three- and four-point loading show significant variability of the postcracking behavior. Regardless the loading differences and the setup of the specimens, a considerable variation in the deformation response can be observed for all series beams which is mainly attributed to the fibre distribution and orientation in the crack section.

2. For the determination of the residual strength of SFRC in tension, a simple method based on the general principles of material mechanics was proposed. Unlike the standard methods based on the empirical relations and related to the specific geometry of the test specimens (methods proposed by RILEM TC 162-TDF, Model Code 2010, DAfStb-Richtlinie), the proposed algorithm is based on general principles of material mechanics. The main advantage of the proposed inverse technique is its capability to calculate residual stresses and, thus, crack width or deflection, at any load level. 
3. To verify the residual strength defined by proposed inverse technique and methods provided by RILEM TC 162-TDF, Model Code 2010, DAfStbRichtlinie and Naaman, a nonlinear FE analysis software ATENA was utilized. The residual strength results attained by the proposed algorithm were found to be accurate when applied for the deformation analysis of the standard three-point loading SFRC beams.

4. The residual strength defined from the experimental results of standard flexural beams can assure adequate modelling results of the deformation behaviour of SFRC members without bars, however it is not capable to provide satisfactory serviceability analysis results of SFRC beams with bar reinforcement. 


\section{Cracking and Deformation Analysis of Steel Fibre Reinforced Concrete Beams with Bar Reinforcement}

This Chapter describes a modelling approach to predict the serviceability behaviour of SFRC beams with steel bar reinforcement. The proposed technique deals with the discrete cracking phenomenon and is based on stress-transfer approach which is characterized by bond between concrete and reinforcement steel bars. For the more adequate modelling of deformation and cracking the bond damage zone is introduced. The post-cracking SFRC material laws in tension, described in Chapter 2, are applied in the analysis. Experimental results of 11 full scale SFRC beams with steel bars subjected to short-term loading are presented. Comparative analysis between modelled and experimental results shows that the proposed method realistically predicts the load-deformation and cracking response of flexural full-scale SFRC beams with bar reinforcement.

This chapter includes the material presented in journal publications Kaklauskas et al. (2014), Gribniak et al. (2017) and Meškeinas et al. (2017). 


\subsection{Model Based on the Stress-transfer Approach}

\subsubsection{General Assumptions and Basic Principles}

The model is based on the following assumptions:

1. Fibre concrete is considered as a homogenous material with enhanced post-cracking characteristics in tension.

2. To model the post-cracking behaviour of SFRC element, a constant value of the residual strength within the tensile zone of SFRC beam section is assumed.

3. Linear-elastic properties are assumed for reinforcement and plain concrete, both in tension and compression.

4. All cracks form at the cracking load $M_{c r}$ dividing the beam into a number of blocks. For the average deformation and crack spacing analysis, a block length $l_{c r}$ is taken equal to $1.5 l_{t r}$.

5. The analysis is performed in a single block between the adjacent primary cracks. Strain and stress distribution in a block are symmetrical in regard to its centre (Fig. 3.1).

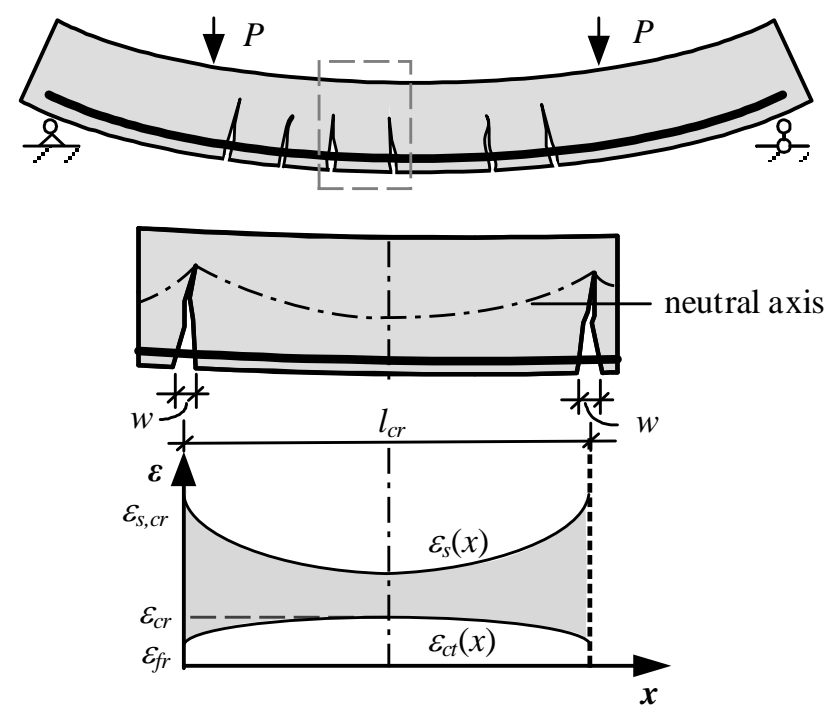

Fig. 3.1. Modelling of a bending member

6. The linear strain distribution within the section is assumed in regard to the tensile reinforcement and compressive concrete. As shown in Fig. 3.2, the strain distribution in the tensile concrete consists of two components: the strain due to tension stiffening and residual strength. 


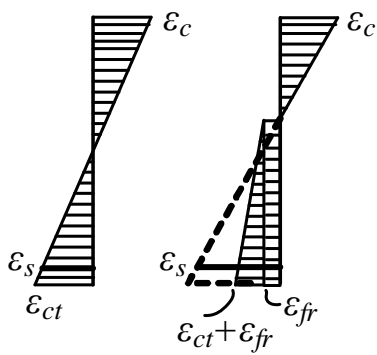

(a)

(b)

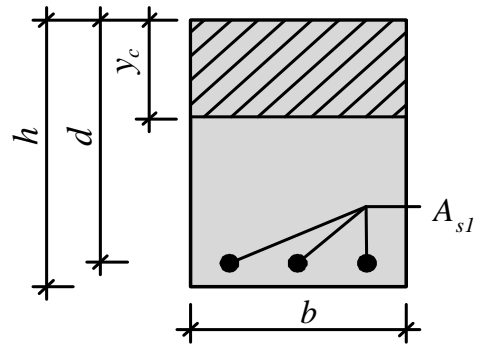

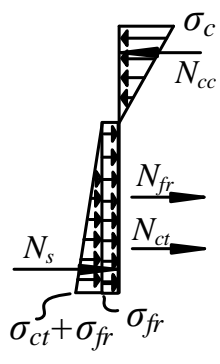

(c)

Fig. 3.2. Strain distribution in the (a) uncracked section, (b) strain and (c) stress distribution in the cracked section

The bond-slip behaviour is modelled by the bond-slip relationship given in Model Code 2010 (fib 2013):

$$
\tau=\tau_{\max } \cdot\left(\frac{s}{s_{1}}\right)^{\alpha} .
$$

Here $\tau_{\max }$ is the maximum bond stress, $\tau_{\max }=2.5 \sqrt{f_{c}} ; s_{1}-$ is the slip corresponding to maximum bond stress, $s_{l}=1 \mathrm{~mm}$.

As it was shown in the research performed by Salem \& Maekawa (1999), Jakubovskis et al. (2013) and Jakubovskis \& Juknys (2016), due to the damage of concrete close to the crack section bond deterioration occurs. The parts affected by the damage of bond are further called the damage zones. According to the Model Code 2010, the length of the damage zone is taken $l_{d}=5 \varnothing$ (here $\varnothing$ is the diameter of steel bar reinforcement). Within the length of the damage zone, the bond stresses are defined as (Fig. 3.3a):

$$
\tau=\tau_{\max } \cdot\left(\frac{s}{s_{1}}\right)^{\alpha} \cdot \lambda .
$$

Here $\lambda$ is the bond reduction factor. The Model Code 2010 assumes that $\lambda$ increases linearly from 0 in the crack to 1 at the end of the damage zone.

Kaklauskas (2017) and Juknys (2017) suggested the length of the damage zone to be related not only to the diameter of the bar, but also to the reinforcement deformation in the crack, representing the load intensity. Following the above, the current study assumes the length of the damage zone quantified in Fig. 3.3b. 


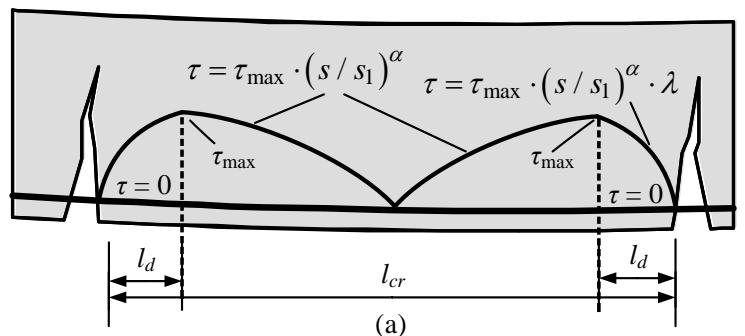

(a)

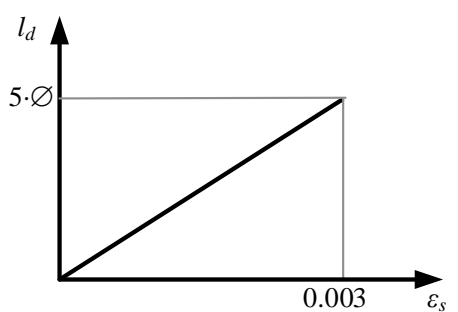

(b)

Fig. 3.3. Damage zone assessment: (a) nonlinear bond stress function in the damage zone and (b) damage zone model

\subsubsection{Calculation Algorithm}

The method for calculation of deformations and average crack spacing of the SFRC beams with bar reinforcements is described as follows. Considering a SFRC beam with bar reinforcement shown in Fig. 3.1, the segment between cracks is subdivided in a number of blocks, each with a length of $\Delta l$. Half of the segment is considered in the analysis assuming symmetrical strain distribution in regard to its centre (Fig. 3.4). Incrementally applying the load $M_{\text {ext }}$, equilibrium, constitutive and bond equation groups are iteratively solved until boundary conditions are satisfied. Analysis is terminated when the yielding of reinforcement is reached:

$$
M_{u}=f_{y} \cdot A_{s} \cdot\left(d-\frac{f_{y} \cdot A_{s}}{2 \cdot f_{c} \cdot b}\right) .
$$

Curvature and distance between cracks of flexural SFRC member are calculated by the following algorithm. For the section "1" (Fig. 3.4) the initial values of steel and concrete deformations as well as compressive zone height $y_{c}$ are defined:

1. For $i=1$ (section " 1 " in Fig 3.4), value of $y_{c, i}$ is calculated. Random upper $y_{c, u}$ and lower $y_{c, l}$ boundaries are defined. For the first iteration, $y_{c, i}=y_{c, u}$ is assumed.

2. Tensile steel $\varepsilon_{s, i}$ and tensile concrete $\varepsilon_{c t, i}$ as well as compressive concrete $\varepsilon_{c c, i}$ strains are calculated. Two equilibrium equations must be satisfied. The first one is written for bending moments:

$$
M_{s, i}+M_{f r, i}+M_{c c, i}-M_{e x t, i}=0 .
$$

Here $M_{\text {ext }, i}$ is the external bending moment; $M_{s, i}$ and $M_{c c, i}$ are the internal moments of steel reinforcement and compressive concrete, respectively. $M_{f r, i}-$ is the moment of corresponding residual strength, as shown in Fig. 3.2c. The second equilibrium equation must be also met: 


$$
N_{s, i}+N_{f r, i}-N_{c c, i}=0 .
$$

If the agreement of the equilibrium equation (3.5) is not within the assumed error limits, the iteration procedure is repeated, assuming the value of $y_{c, i} \mathrm{calcu}-$ lated by the bisection method:

$$
y_{c, i}=\left(y_{c, u}+y_{c, \mathrm{i}}\right) / 2 .
$$

The calculations are terminated when the convergence is reached and values of steel and concrete deformations $\varepsilon_{s, i}$ and $\varepsilon_{c t, i}$ are defined.

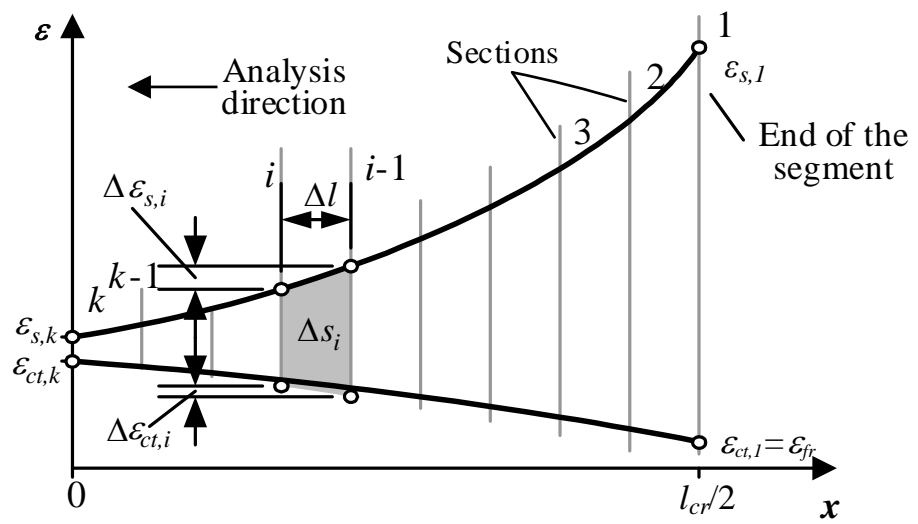

Fig. 3.4. Deformation analysis of SFRC beam with bar reinforcement

For the cracking and deformation analysis, the following iterative procedure is performed. Considering a block between sections $i$ and $i+1$ (Fig. 3.4), the following procedure is carried out:

1. The initial slip value $s_{\text {init }}$ is randomly assumed (in this analysis $s_{\text {init }}$ was assumed equal to $0.002 \mathrm{~mm}$ ). The strain values of tensile steel $\varepsilon_{s, i}$, tensile concrete $\varepsilon_{c f, i}$, compressive concrete $\varepsilon_{c c, i}$ and $y_{c, i}$ are assumed from previous calculations. In the next steps, the iterative procedure to define value of $y_{c, i}$ is performed.

2. The steel strain is calculated:

$$
\varepsilon_{s, i}=\varepsilon_{s, i-1}-\frac{\left(\tau_{i}+\tau_{i-1}\right)}{2} \frac{\pi \cdot d \cdot \Delta l_{i}}{E_{s} \cdot A_{s}} .
$$

3. Concrete compressive and tensile strains are calculated:

$$
\varepsilon_{\mathrm{cc}, i}=\varepsilon_{s, i} \cdot y_{c, i} /\left(d-y_{c, i}\right) .
$$




$$
\varepsilon_{\mathrm{ct}, i}=\frac{\varepsilon_{\mathrm{cc}, i} \cdot E_{c} \cdot b \cdot y_{c, i} / 2-\varepsilon_{s, i} \cdot E_{s} \cdot A_{s}-\sigma_{f r} \cdot b \cdot\left(h-y_{c, i}\right)}{E_{c} \cdot\left(h-y_{c, i}\right) \cdot b / 2} .
$$

4. Concrete tensile strain at the level of the reinforcement is defined:

$$
\varepsilon_{c t s, i}=\frac{\varepsilon_{c t} \cdot\left(h-y_{c, i}-d\right)}{\left(h-y_{c, i}\right)+\sigma_{f r} / E_{c}} .
$$

5. Slip increment $\Delta s_{i}$ is calculated:

$$
\Delta s_{i}=\Delta l_{i}\left(\frac{\varepsilon_{s, i}+\varepsilon_{s, i-1}}{2}-\frac{\varepsilon_{c t s, i}+\varepsilon_{c t s, i-1}}{2}\right) .
$$

6. The slip at the section $i$ is defined:

$$
s_{i}=s_{i-1}-\Delta s_{i} .
$$

7. The bond stress $\tau_{i}$ by the assumed bond-slip law (eq. 3.2) is calculated.

8. Moment equilibrium equation is solved:

$$
M_{s, i}+M_{f r, i}+M_{c c, i}-M_{e x t}=0 .
$$

If the agreement of the equilibrium equation (eq. 3.13) is not within the assumed error limits, the iteration procedure is repeated from step 2 until the convergence is reached. For each iteration value of $y_{c, i}$ is defined by the bisection method.

9. The iteration procedure, starting from the first step, is repeated to the next block, until the slip at the section $k$ is defined.

10. The reinforcement slip value between the cracks is calculated:

$$
s=\sum_{i=1}^{k} \Delta s_{i} .
$$

11. If the assumed initial $s_{\text {init }}$ and calculated $s$ slip values are within the defined tolerance, the calculations are terminated. Otherwise, iteration procedure is repeated from the step 1, assuming initial slip value defined by secant method:

$$
s_{k}=s_{k-1}-\left(s_{k-1}-\sum_{i=1}^{k-1} \Delta s_{i}\right) \cdot\left[\frac{\left(s_{k-1}-s_{k-2}\right)}{s_{k-1}-\sum_{i=1}^{k-1} \Delta s_{i}-s_{k-2}-\sum_{i=1}^{k-2} \Delta s_{i}}\right] .
$$

12. The crack spacing is defined:

$$
l_{c r}=2 \cdot \sum_{i=1}^{k} \Delta l_{i} .
$$


13. Curvature $\kappa_{i}$ at corresponding load $M_{\text {ext }}$ is defined:

$$
\kappa=\frac{\varepsilon_{s, k}+\varepsilon_{c c, k}}{d}
$$

\subsection{Experimental Investigation}

An experimental program was performed to investigate the combined effect of steel fibres and bars reinforcement on the response of beams subjected to short term four-point loading. Eleven full-scale beams with various fibre volumes and tensile steel bar reinforcement ratios were tested to failure. Crack spacing and moment-curvature behaviour was experimentally defined.

\subsubsection{Specimen Layout and Test}

Eleven steel fibre reinforced concrete beams with bar reinforcement were produced and tested under a four-point loading. All beams had a span of $3000 \mathrm{~mm}$, with a nominal length of 3100 or $3280 \mathrm{~mm}$. The beams had the same nominal cross-section parameters with the depth of $300 \mathrm{~mm}$ and width of $280 \mathrm{~mm}$. Longitudinal and cross-sectional reinforcement of the specimens is shown in Figs 3.5 and 3.6. Different series of beams were reinforced with traditional bar reinforcement ratio of $p=1.0,0.6$ and $0.3 \%$ for Series 1,2 and 3, respectively. Tested beams contained from $23.5 \mathrm{~kg} / \mathrm{m}^{3}$ to $118 \mathrm{~kg} / \mathrm{m}^{3}$ hooked-ended steel fibres, equivalent to $0.3,0.5,0.6,1.0$ and $1.5 \%$ of the total specimen volume. Reference beams without fibres were casted for each series of beams.
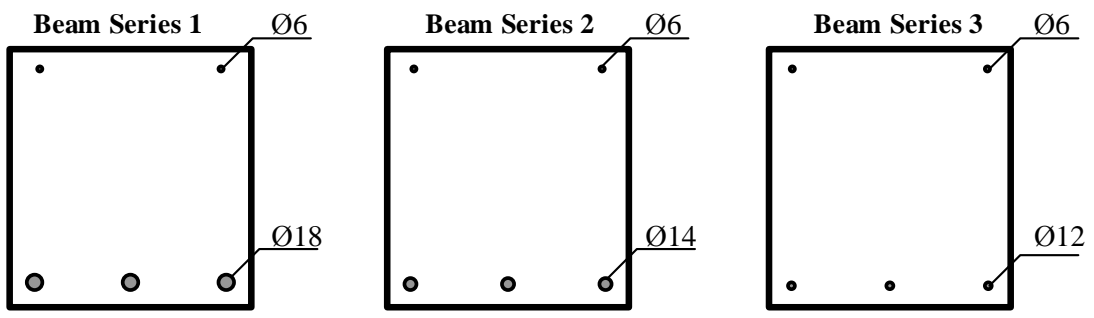

Fig. 3.5. Cross-sections of experimental beams

The specimens were reinforced with three 18 and $14 \mathrm{~mm}$ tensile reinforcement bars for Series 1 and 2 respectively, and two $12 \mathrm{~mm}$ bars for Series 3 (Fig. 3.5). For the top reinforcement of all beams, two $\varnothing 6 \mathrm{~mm}$ bars (reinforcement grade S500) were used. To avoid shear failure, the $\varnothing 6 \mathrm{~mm}$ stirrups with $100 \mathrm{~mm}$ 
spacing were used as shown in Fig. 3.6 a. Main parameters and characteristics of the experimental beams are listed in Table 3.1.

Table 3.1. Main characteristics of the test beams

\begin{tabular}{|c|c|c|c|c|c|c|c|c|c|c|}
\hline \multirow{2}{*}{\multicolumn{2}{|c|}{ Beam }} & $A_{s I}$ & $A_{s 2}$ & \multirow{2}{*}{$\frac{a_{s 2}}{\mathrm{~mm}}$} & $p$ & $V_{f b}$ & \multirow{2}{*}{\multicolumn{4}{|c|}{\begin{tabular}{c|r}
$f_{s}$ & $\boldsymbol{E}_{\boldsymbol{c}}$ \\
\multicolumn{2}{|c|}{$\mathbf{M P a}$}
\end{tabular}}} \\
\hline & & \multicolumn{2}{|c|}{$\mathbf{m m}^{2}$} & & \multicolumn{2}{|c|}{$\%$} & & & & \\
\hline \multirow{4}{*}{ 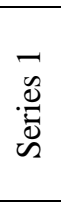 } & S1-3 & 755 & 57 & 23 & 1.0 & 0.0 & 48.13 & 632.3 & 36806 & 210505 \\
\hline & S1-F05 & 798 & 56 & 21 & 1.0 & 0.5 & 55.62 & 558.7 & 38342 & 205304 \\
\hline & S1-F10 & 798 & 56 & 20 & 1.0 & 1.0 & 47.95 & 558.7 & 36733 & 205304 \\
\hline & S1-F15 & 798 & 56 & 21 & 1.0 & 1.5 & 52.15 & 558.7 & 37735 & 205304 \\
\hline \multirow{4}{*}{ 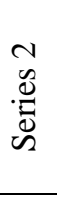 } & S2-3 & 466 & 57 & 29 & 0.6 & 0.0 & 48.20 & 582.4 & 36791 & 207256 \\
\hline & S2-F05 & 477 & 56 & 25 & 0.6 & 0.5 & 55.62 & 563.6 & 38342 & 213384 \\
\hline & S2-F10 & 477 & 56 & 22 & 0.6 & 1.0 & 47.95 & 563.6 & 36733 & 213384 \\
\hline & S2-F15 & 477 & 56 & 23 & 0.6 & 1.5 & 52.15 & 563.6 & 37735 & 213384 \\
\hline \multirow{3}{*}{$\begin{array}{l}n \\
\tilde{\omega} \\
\stackrel{\omega}{0} \\
\tilde{n}\end{array}$} & B-1-F0 & 226 & 56 & 23 & 0.3 & 0.0 & 64.47 & 800.0 & 40180 & 194155 \\
\hline & B-2-F03 & 226 & 56 & 23 & 0.3 & 0.3 & 65.30 & 800.0 & 40346 & 194155 \\
\hline & B-3-F06 & 226 & 56 & 23 & 0.3 & 0.6 & 62.27 & 800.0 & 39767 & 194155 \\
\hline
\end{tabular}

Here $A_{s 1}$ and $A_{s 2}$ are the cross-section areas of top and bottom reinforcement, respectively; $\rho_{l}$ is the reinforcement ratio of tensile (bottom) reinforcement; $V_{f}$ is the volume content of fibres in the concrete mixture; $f_{c}$ is the $\varnothing 150 \times 300 \mathrm{~mm}$ cylinder strength; $E_{c}$ is the elastic modulus of the concrete; $f_{y}$ and $E_{s}$ are the yielding strength and the elastic modulus of the bar reinforcement, respectively.

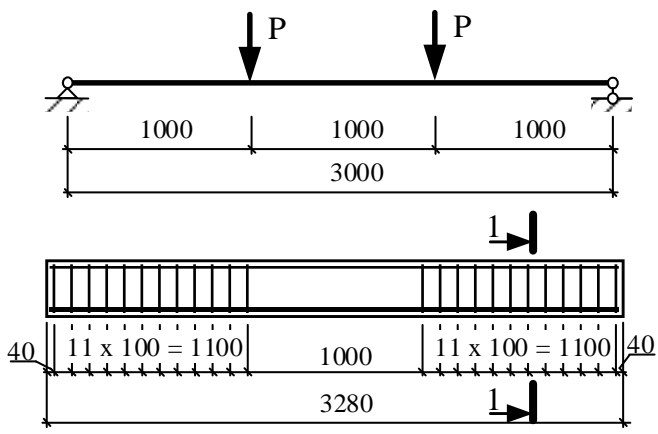

(a)

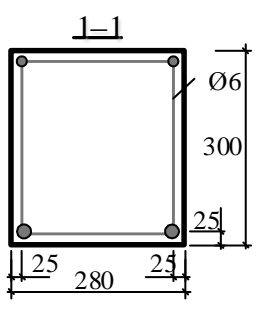

(b)

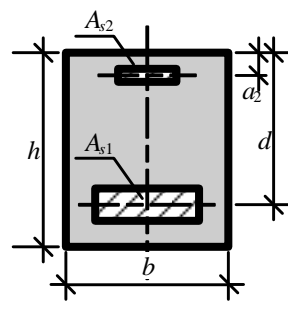

(c)

Fig. 3.6. Experimental beams: (a) loading scheme, (b) scheme of reinforcement and (c) cross-section of the beams 
The experimental beams and concrete specimens were cured under the laboratory conditions at average relative humidity (RHm) 65.5\%. The beams were demoulded in about 2-3 days after casting. In the test set-ups with four loading points, two line loads were applied at the thirds of the beam free span.

The full-scale beams were tested using ПР-1000 testing machine. Load was applied with $2 \mathrm{kN}$ increments only pausing for short period (about 1-2 minutes) to take readings of the gauge and to measure crack development. Magnitude of the load was observed using digital $500 \mathrm{kN}$ dynamometer (load cell). The load was applied to the beam through steel traverse (length of traverse $-1250 \mathrm{~mm}$ ); 10 $\mathrm{mm}$ steel plates were glued at the load application place in order to avoid a stress concentration. Arrangement of the testing equipment are shown in Fig. 3.7.
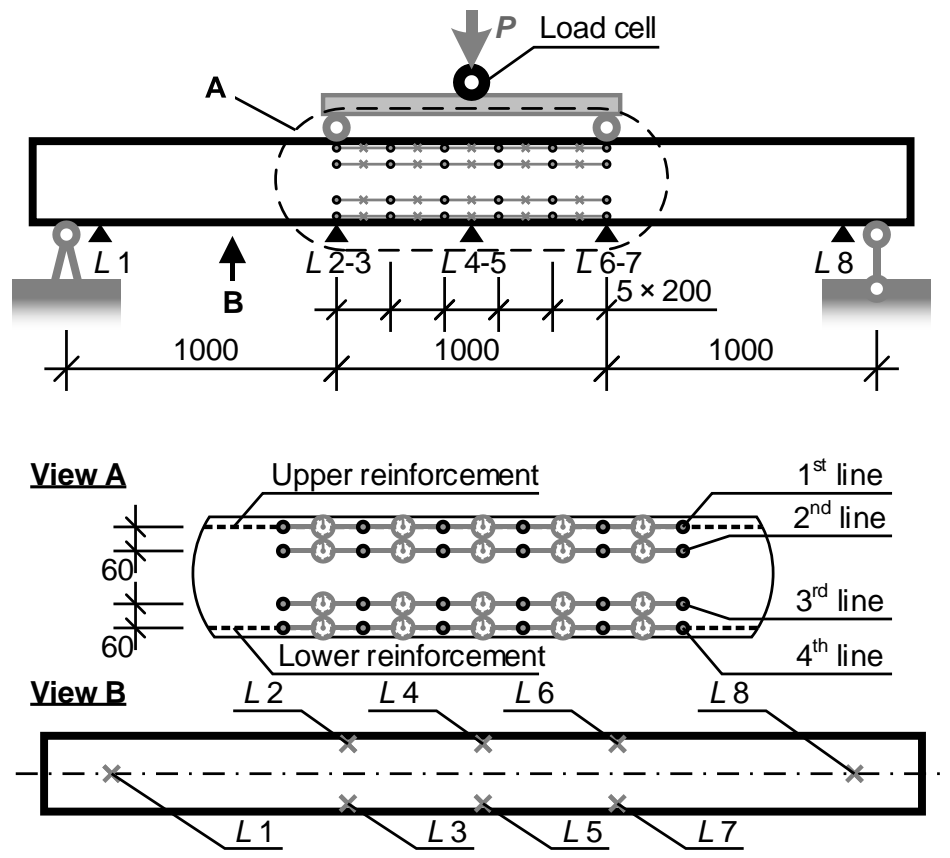

Fig. 3.7. Structural system and arrangement of the measurements

Concrete surface strain was measured using 20 mechanical micrometres with circular scale (indicator), which accuracy $- \pm 0.003 \mathrm{~mm}$. Gauge length $-200 \mathrm{~mm}$. Concrete surface strains were measured in pure bending zone at the four different levels and at the five sections of every level. The readings of indicators were taken at every load stage.

Concrete surface strain was measured using 20 mechanical micrometres with circular scale (indicators) with accuracy $\pm 0.003 \mathrm{~mm}$ (gauge length $=200 \mathrm{~mm}$ ). 
As shown in Fig. 3.7 (view 'A') and Fig. 3.8, four continuous gauge lines (with five mechanical gauges in each line) were located at different heights. The two extreme gauge lines were placed along the top and the bottom reinforcement whereas two other lines were located $60 \mathrm{~mm}$ off these lines. The readings of indicators were taken at every load stage. To measure deflections, linear variable displacement transducers (LVDT) (L1-L8, see Fig. 3.7) were placed beneath the soffit of each of the beams. The LVDTs ALMEMO T50 with an accuracy of $\pm 0.15 \%$ were used for this purpose. The LVDTs and dynamometer were connected to a personal computer through signal processing equipment ALMEMO 25 90-9 and the readings were taken every second.

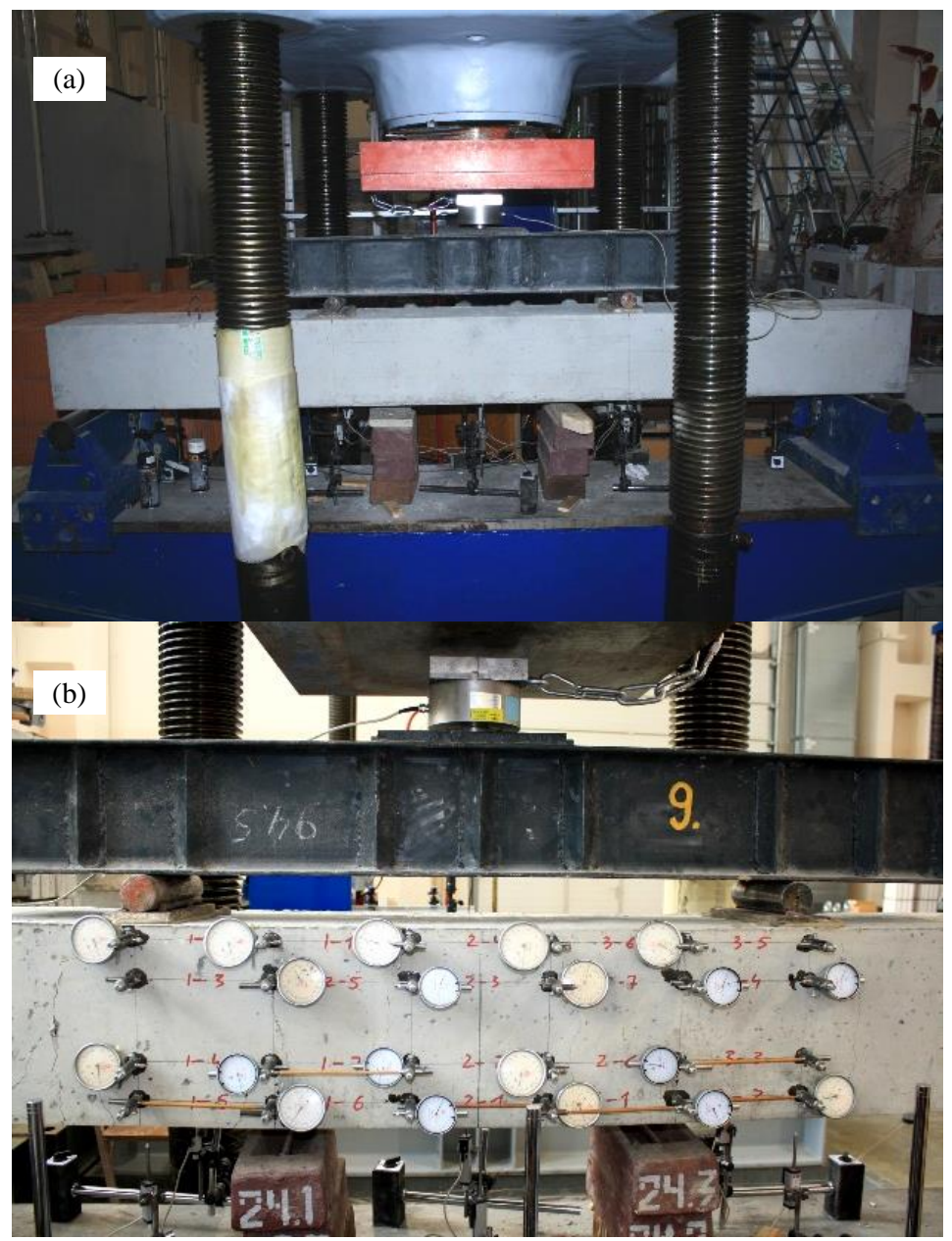

Fig. 3.8. Experimental set-up of the beam: (a) loading and (b) strain measurement 
The cracking moment $M_{c r}$ of every beam was determined using LVDTs and mechanical micrometres as well as visual examination of the occurrence of the first crack. Ultimate moment $M_{u}$ was measured at the end of the test. Testing results are analysed in Subsection 3.2.3.

\subsubsection{Material Properties}

Two concrete compositions were used in this experimental program; one for Series 1 and 2 full scale SFRC beams and another for Series 3 beams. Readymixed concrete manufactured in UAB "Markuciai" was used for producing experimental specimens. The dry compositions of all concrete mix designs used in this experimental program per cubic metre are listed in the Table 3.2. Seven different batches with distinct contents of fibres were used. For the Composition 1 fibre volumes of $39.3,78.5$ and $117.8 \mathrm{~kg} / \mathrm{m}^{3}$ were used while for Composition 2 $23.5 \mathrm{~kg} / \mathrm{m}^{3}$ and $47 \mathrm{~kg} / \mathrm{m}^{3}$ of hooked end steel fibres were added. Moreover, plain concrete mixtures were produced for both Compositions.

Table 3.2. Concrete compositions for $1 \mathrm{~m}^{3}$

\begin{tabular}{|c|c|c|c|c|c|c|c|c|c|}
\hline \multirow{2}{*}{ Ingredients } & \multicolumn{5}{|c|}{ Composition 1 } & \multicolumn{3}{c|}{ Composition 2 } \\
\cline { 2 - 8 } & FRC1 & FRC2 & FRC3 & FRC4 & FRC5 & FRC6 & FRC7 \\
\cline { 2 - 8 } & \multicolumn{7}{|c|}{ Amount, kg/m 3} \\
\hline Sand 0/4 mm & 905 & 905 & 905 & 905 & 885 & 885 & 885 \\
\hline $\begin{array}{c}\text { Crushed aggregate } \\
\text { 5/8 mm }\end{array}$ & 388 & 388 & 388 & 388 & - & - & - \\
\hline $\begin{array}{c}\text { Crushed aggregate } \\
\text { 11/16 mm }\end{array}$ & 548 & 548 & 548 & 548 & - & - & - \\
\hline $\begin{array}{c}\text { Crushed aggregate } \\
\text { 4/16 mm }\end{array}$ & - & - & - & - & 975 & 975 & 975 \\
\hline $\begin{array}{c}\text { Cement CEM I } \\
42.5 \text { N }\end{array}$ & 400 & 400 & 400 & 400 & 380 & 380 & 380 \\
\hline Concrete plasticizer & 1.7 & 1.8 & 2.0 & 2.2 & 1.7 & 1.7 & 1.7 \\
\hline Concrete retarder & - & - & - & - & 1.9 & 1.9 & 1.9 \\
\hline Water & 123.8 & 123.8 & 123.8 & 123.8 & 160 & 160 & 160 \\
\hline Duoloc fibres & - & 39.3 & 78.5 & 117.8 & - & - & - \\
\hline $\begin{array}{c}\text { Mechel Nemunas } \\
\text { fibres }\end{array}$ & - & - & - & - & - & 23.6 & 47.1 \\
\hline
\end{tabular}

The concrete mix was designed to obtain a material with good compactability properties. Therefore, the fresh state properties of the SFRC were evaluated with 
a slump flow test (Fig. 3.9). The test also allows a qualitative evaluation of the material stability by analysing segregation such as irregular distribution of coarse aggregates, existence of coarse aggregates without mortar or separation of the paste around the perimeter. No sign of segregation was detected, the mixture showed good homogeneity. A total spread of around $600 \mathrm{~mm}$ was measured for all concrete compositions. Another parameter attained during the test was the time to reach a spread diameter of $500 \mathrm{~mm}$. An average 20 seconds for all mixtures was measured.

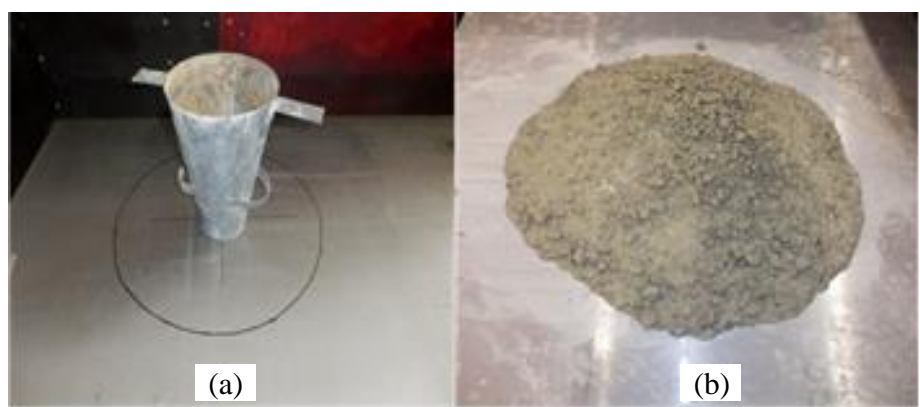

Fig. 3.9. Slump flow test: (a) used cone and (b) spread of steel fibre reinforced concrete

Cubes $(100 \times 100 \times 100 \mathrm{~mm}$ and $150 \times 150 \times 150 \mathrm{~mm})$ and cylinders $(\mathrm{d}=150 \mathrm{~mm})$ were produced for determination of compressive strength of plain concrete and SFRC. Modulus of elasticity of concrete was measured testing cylinders $(\mathrm{d}=150 \mathrm{~mm})$. The average results at 28 days for the compressive strength $\left(f_{c}\right)$ and modulus of elasticity $\left(E_{c}\right)$ of each batch are presented in Table 3.3.

Table 3.3. Concrete compressive strength and modulus of elasticity

\begin{tabular}{|c|c|c|c|c|c|c|c|}
\hline \multirow{2}{*}{ Parameter } & \multicolumn{4}{|c|}{ Composition 1 } & \multicolumn{3}{c|}{ Composition 2 } \\
\cline { 2 - 8 } & FRC1 & FRC2 & FRC3 & FRC4 & FRC5 & FRC6 & FRC7 \\
\hline $\boldsymbol{f}_{\boldsymbol{c}}, \mathbf{M P a}$ & 48.20 & 55.62 & 47.95 & 52.15 & 64.47 & 65.30 & 62.27 \\
\hline $\boldsymbol{E}_{\boldsymbol{c}}, \mathbf{M P a}$ & 36791 & 38342 & 36733 & 37735 & 40180 & 40346 & 39767 \\
\hline $\boldsymbol{V}_{\boldsymbol{f} \boldsymbol{b}}, \boldsymbol{\%}$ & 0 & 0.5 & 1.0 & 1.5 & 0 & 0.3 & 0.6 \\
\hline
\end{tabular}

Deformed bars of mild steel with diameters of $\emptyset 14$ and $\emptyset 18 \mathrm{~mm}$ were used for the main reinforcement of Series 1 and Series 2 full scale beams, whereas for Series 3 beams $\emptyset 12$ high strength steel bars were employed. Three specimens of each diameter were tested for determining material characteristics (modulus of 
elasticity, yielding stress). The length of each specimen was about $500 \mathrm{~mm}$. Tensile testing machine was used for reinforcement specimen testing. Load was increasing by constant rate. Reinforcement deformations were measured by LVDTs ALMEMO T50. Experimental reinforcement characteristics are presented in Table 3.1.

\subsubsection{Experimental Results}

The moment-curvature relationships of the full-scale beams are shown in Figs 3.10, 3.11 and 3.12. Concrete surface strains were measured in pure bending zone at four different levels and at five sections of every level. As described in Subsection 3.2.1, deflections of the beam were measured with LVDTs ALMEMO T50. Moment-curvature diagrams were obtained by two methods: from average surface strains and from deflections over pure bending zone. It can be seen, that moment-curvature diagrams obtained by both methods are in good agreement. Further analysis will be based on data derived from the average strains.

While increasing load, the beams had a linear behaviour before appearing the first crack and further non-linear response was observed until failure. The tests were stopped when the theoretical ultimate strain of the steel for beam Series 1 and 2 and high-grade steel for Series 3 reinforcement was reached.

Figures $3.13,3.14$ and 3.15 present comparison of moment-curvature curves for the beam Series 1, 2 and 3, respectively. Although a significant difference in the deformational behaviour can be observed between the reference and SFRC beams, the change in the volume of fibres from $0.5 \%$ to $1.0 \%$ for Series 1 and 2 or from $0.3 \%$ to $0.6 \%$ for Series 3 beams does not have a significant impact on the flexural stiffness.

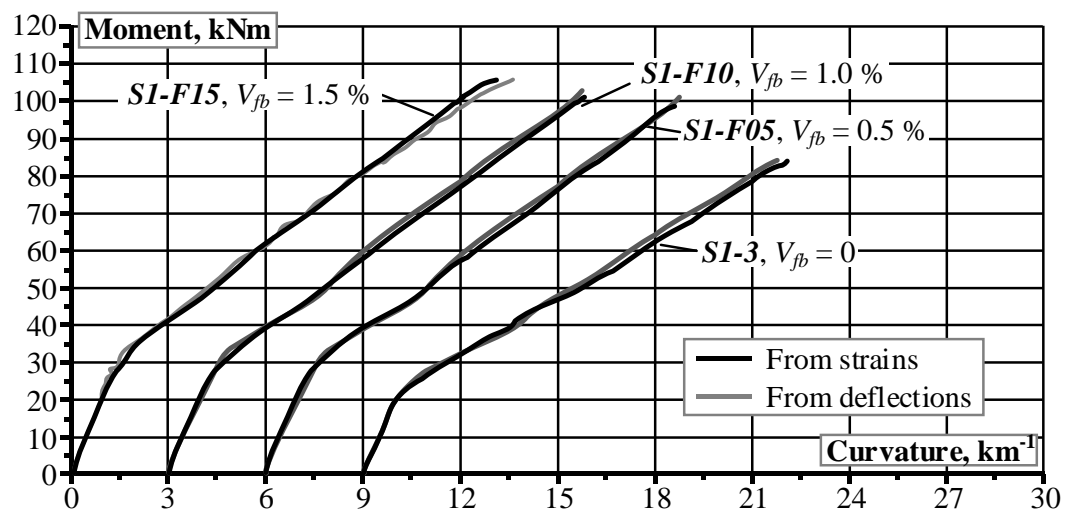

Fig. 3.10. Moment-curvature relationships of experimental Series 1 beams derived from mid-span deflections and surface deformations 


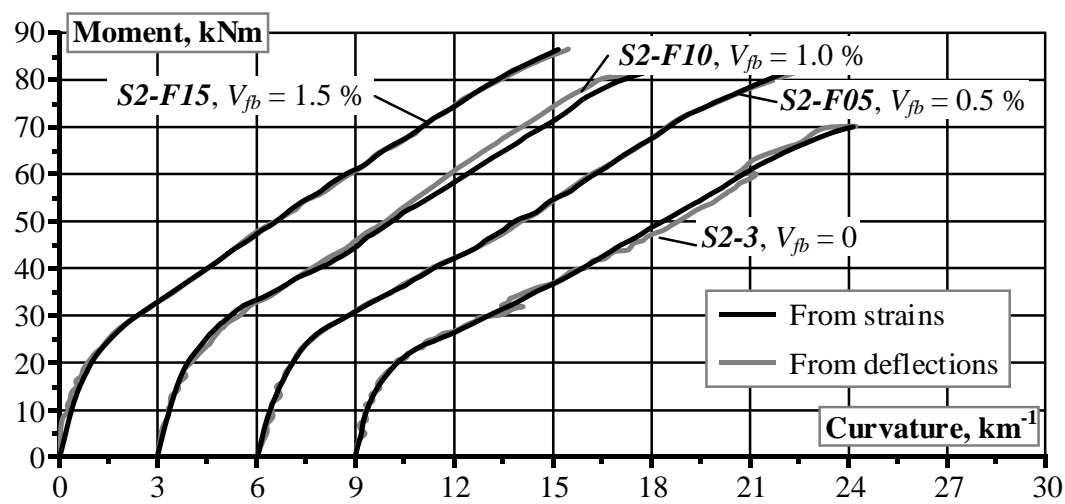

Fig. 3.11. Moment-curvature relationships of experimental Series 2 beams derived from mid-span deflections and surface deformations

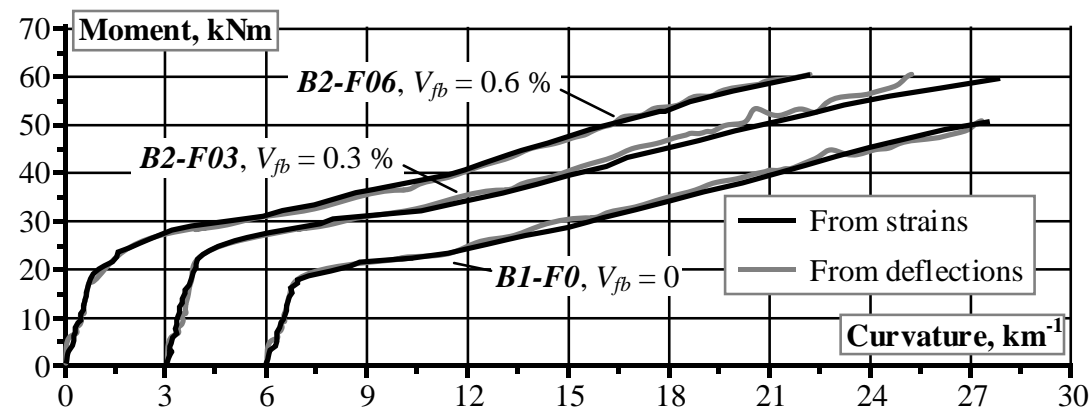

Fig. 3.12. Moment-curvature relationships of experimental Series 3 beams derived from mid-span deflections and surface deformations

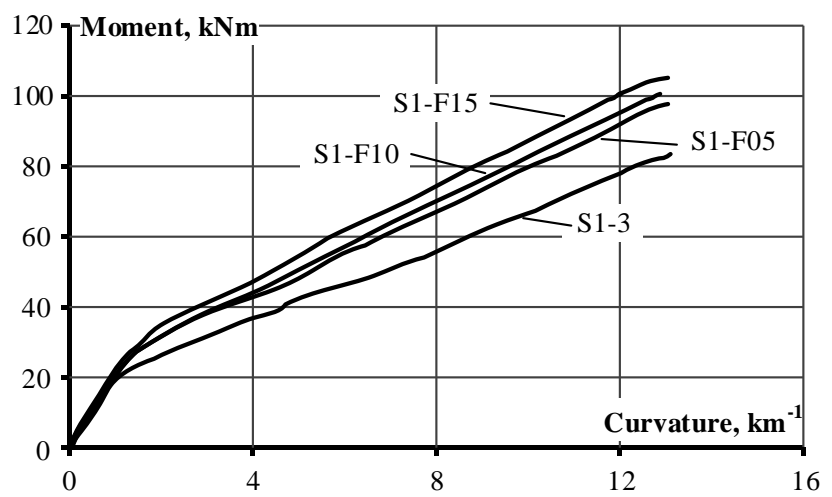

Fig. 3.13. Moment-curvature relationships of experimental Series 1 beams 


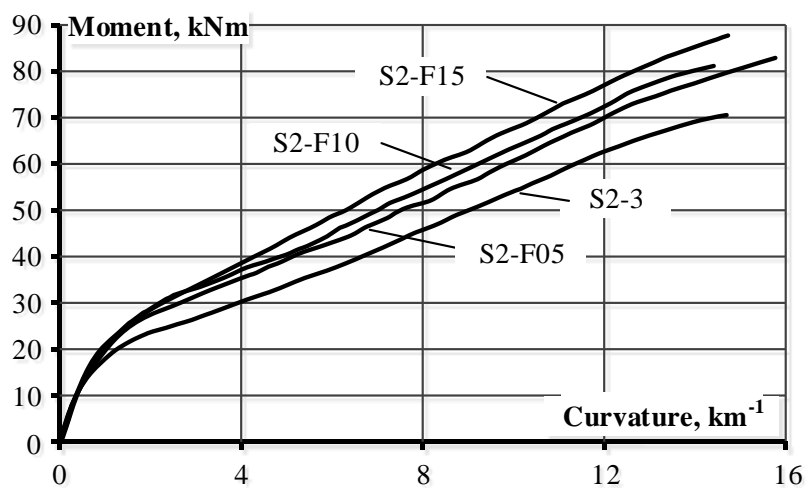

Fig. 3.14. Moment-curvature relationships of experimental Series 2 beams

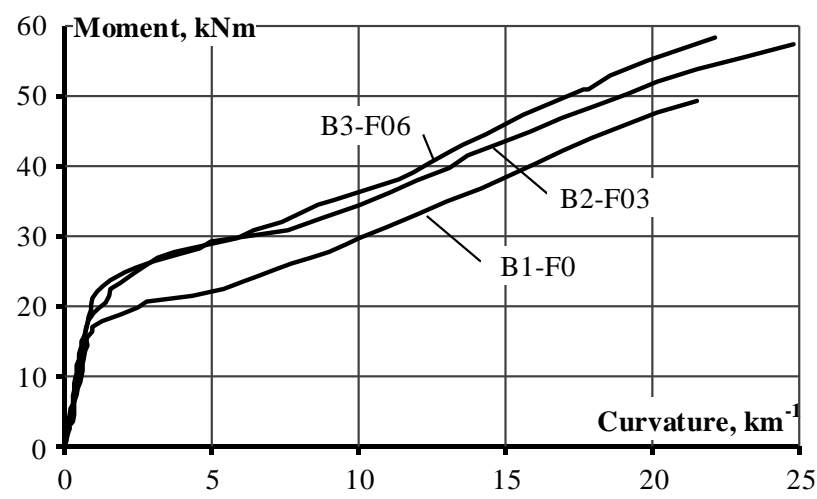

Fig. 3.15. Moment-curvature relationships of experimental Series 3 beams

The crack patterns of all experimental beams are presented in Figs 3.16, 3.17 and 3.18 for Series 1, 2 and 3 beams, respectively. Dashed line rectangular represents the pure bending zone. The crack patterns of Series 1 and 2 beams indicate that the addition of steel fibres leads to the formation of more cracks with smaller spacing. This is mainly influenced by the post-cracking behaviour of SFRC and the improvement of stress transfer in the cracks due to the presence of fibres, leading to the reduction of the bond transfer length. In case of lower fibre volumes (see beams S1-F05 and S2-F05) the number of main cracks increased only by one or two with respect to RC beams. However, a crack ramification was detected in the SFRC beams, especially those with a higher fibre content (S1-F15 and S2-F15 in Figs 3.16 and 3.17). The Series 3 beams shown in the Fig. 3.18 reveals the same tendency - increase of fibre volume (from $0.3 \%$ to $0.6 \%$ ) practically has no influence on the crack number. 


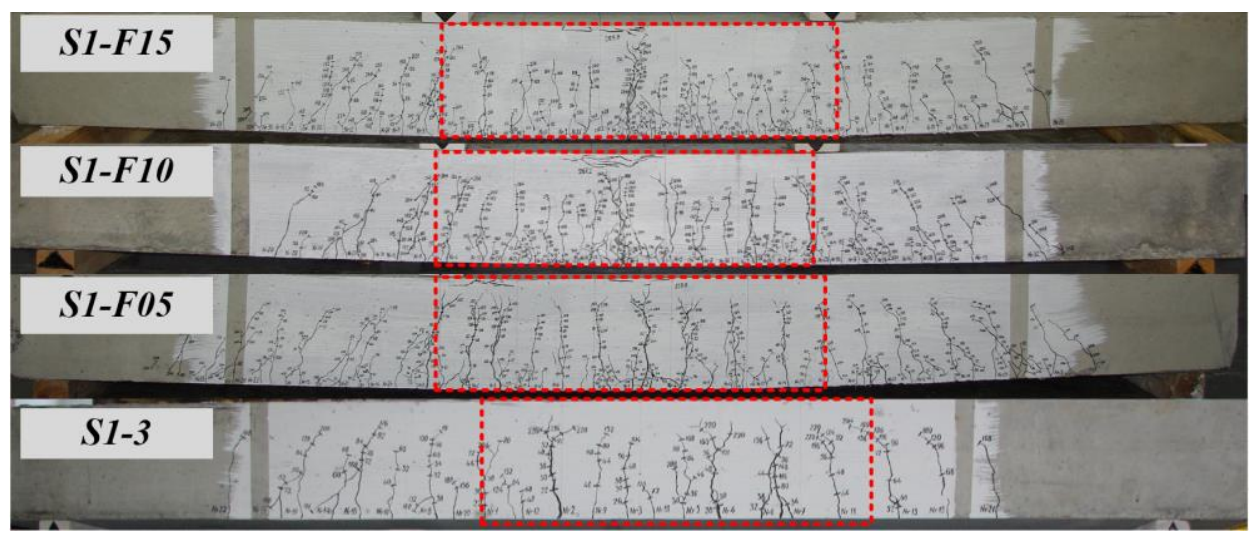

Fig. 3.16. The final crack pattern of Series 1 beams

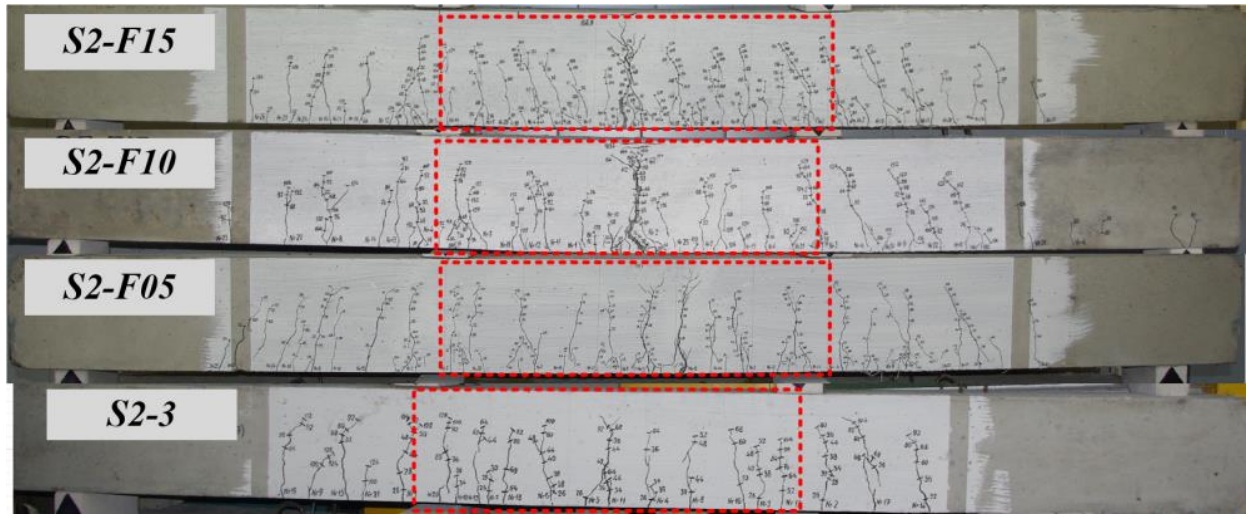

Fig. 3.17. The final crack pattern of Series 2 beams

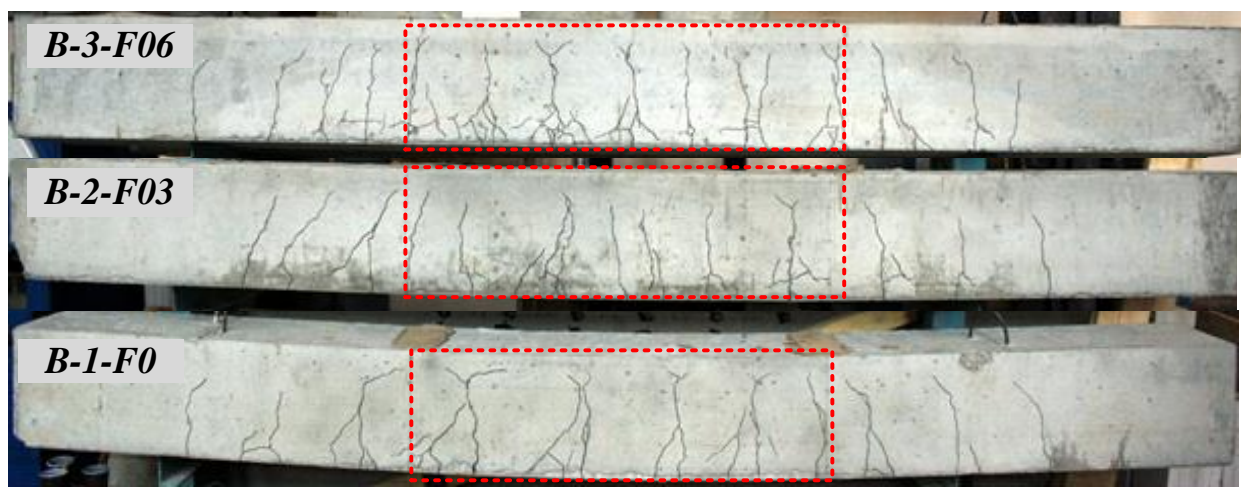

Fig. 3.18. The final crack pattern of Series 3 beams 
A common characteristic observed in all the elements is the symmetry in the formation of the cracks in both sides of the beam. The cracking patterns revealed that the first cracks which are noticeable for the naked eye appeared at different load levels, mainly related to the fibre content. In the case of the SFRC beams with lower contents and for the RC elements without fibres the first crack appears at the load of $20 \mathrm{kN}$, while for higher fibre content, cracking is postponed and the first crack become visible at $30 \mathrm{kN}$. Almost all of the cracks had already appeared at $35 \mathrm{kN}$ for lightly reinforced beams ( $p=0.3 \%$, Series 3 beams), $50 \mathrm{kN}$ for Series 2 beams $(p=0.6 \%)$ and $60 \mathrm{kN}$ for Series 3 beams $(p=1.0 \%)$. However from that load until the end of the test a significant growth in crack widths as well as the ramification of cracks occurred.

For the SFRC beams, especially with higher volume of fibres, ramification leading to horizontal cracks was observed in the section where longitudinal bars were located. Due to the reduction of the area of concrete in the sections where the transversal reinforcement is located, the cracks tend to line up with it.

\subsection{Analysis of the Results}

The proposed algorithm based on stress-transfer approach was applied for the deformation and cracking analysis of the experimental flexural elements described in Section 3.2. Averaged value of the residual strength obtained by Model Code 2010 method and empirical method derived by Naaman were assumed in the calculations. The numerically attained average crack spacing of all beams have been compared with the experimental results. Calculated distances between the cracks are presented in Table 3.4.

The measurements were performed at the central $100 \mathrm{~cm}$ of the beam, i.e. pure bending zone, in order to avoid the interaction with shear forces near the supports. In comparison to the RC beams without fibres, a reduction of the average crack spacing is observed. The effect of bar reinforcement ratio is also observed. Higher reinforcement ratio (such as the Series 1 beams), leads to a higher average number of cracks and, therefore, a lower average crack spacing.

The results of the average crack spacing of reinforced concrete beams without steel fibres show that the proposed algorithm based on the stress-transfer approach assures adequate modelling of the cracking. The prediction errors of the average crack spacing for RC beams without fibres reached $7 \%$ (for lightly reinforced beam B-1-F0, $p=0.3 \%)$ and $4 \%$ for beam S1-3 $(p=0.3 \%)$, whereas for the beam S2-3 ( $p=0.6 \%)$ perfect agreement was attained (Table 3.4). 
Table 3.4. Comparison of experimental and numerically attained average distances between the cracks

\begin{tabular}{|c|c|c|c|c|c|}
\hline \multirow[t]{2}{*}{ Beam } & $l_{c r, e x p}$ & $l_{\text {cr,calc }}$ (Naaman) & $\begin{array}{c}l_{\text {cr,calc }} \\
\text { (MC 2010) }\end{array}$ & \multirow{2}{*}{$\begin{array}{c}\text { Ratio } \\
l_{\text {cr,calc,Naaman }} \\
/ l_{\text {cr,exp }}\end{array}$} & \multirow{2}{*}{$\begin{array}{c}\text { Ratio } \\
l_{c r, c a l c, M C 2010} \\
/ l_{c r, \exp }\end{array}$} \\
\hline & \multicolumn{3}{|c|}{ cm } & & \\
\hline S1-3 & 10.00 & \multicolumn{2}{|c|}{$9.59\left(V_{f b}=0\right)$} & \multicolumn{2}{|c|}{0.96} \\
\hline S2-3 & 10.00 & \multicolumn{2}{|c|}{$10.02\left(V_{f b}=0\right)$} & \multicolumn{2}{|c|}{1.00} \\
\hline B-1-F0 & 22.50 & \multicolumn{2}{|c|}{$20.73\left(V_{f b}=0\right)$} & \multicolumn{2}{|c|}{0.93} \\
\hline S1-F05 & 9.09 & 8.73 & 6.66 & 0.96 & 0.73 \\
\hline S1-F10 & 8.33 & 7.65 & 6.17 & 0.92 & 0.74 \\
\hline S1-F15 & 7.14 & 6.71 & 5.87 & 0.94 & 0.82 \\
\hline S2-F05 & 10.00 & 9.41 & 8.34 & 0.94 & 0.83 \\
\hline S2-F10 & 11.11 & 8.96 & 6.42 & 0.81 & 0.58 \\
\hline S2-F15 & 8.33 & 7.20 & 6.20 & 0.86 & 0.74 \\
\hline B-2-F03 & 15.00 & 17.81 & 16.89 & 1.13 & 1.17 \\
\hline B-3-F06 & 14.29 & 17.12 & 16.34 & 1.14 & 0.83 \\
\hline & & & Average: & 0.98 & 0.85 \\
\hline & & & Variation: & 0.12 & 0.20 \\
\hline
\end{tabular}

The average crack spacing results of SFRC beams with bar reinforcement have shown that application of the residual strength values calculated by Naaman method assures the average prediction error of $2 \%$ (maximum value equal to $14 \%$ ). The variation coefficient of the crack spacing was calculated equal to $12 \%$. Taking into account the relatively large scatter of the cracking process, the obtained error in absolute terms represents very good agreement with the experimental results. The crack spacing results modelled using the residual strength defined by Model Code 2010 fits the experimental results with the average error of $15 \%$ (maximum value equal to $42 \%$ ) and variation coefficient of $20 \%$.

The comparison to the modelled and experimental moment-curvature relationships of the full-scale reinforced concrete beams with and without fibre reinforcement is shown in Figs 3.19, 3.20, 3.21 and 3.22. The analysis of reinforced concrete beams without fibres has shown, that the prediction errors of the deformation behaviour reached only 5\%. This indicates the adequacy of the selected bond-slip and the damage zone laws. 


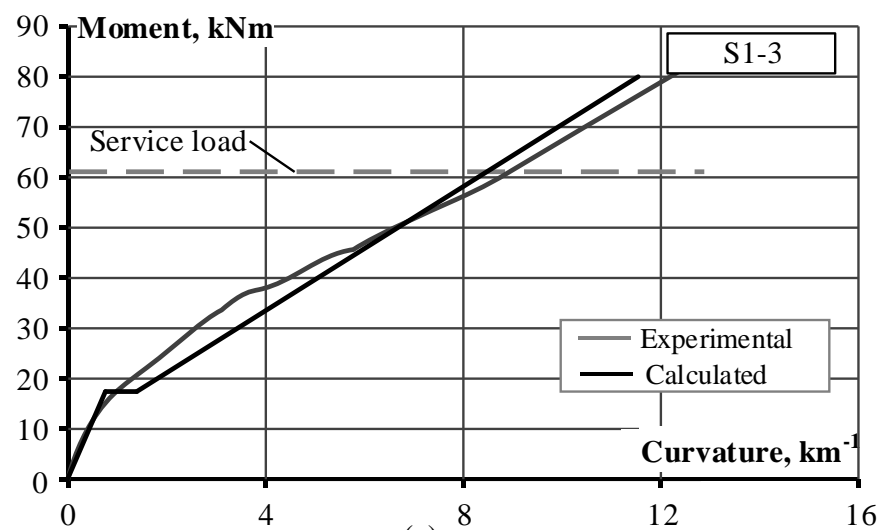

(a)

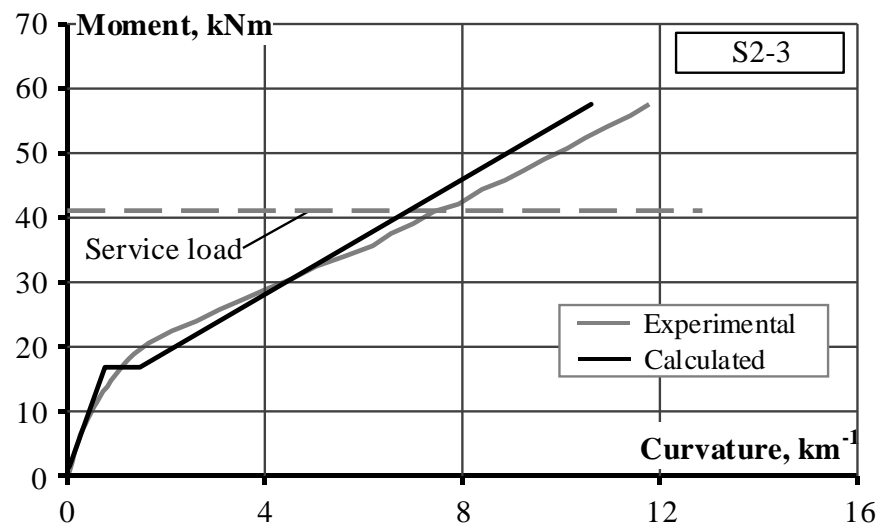

(b)

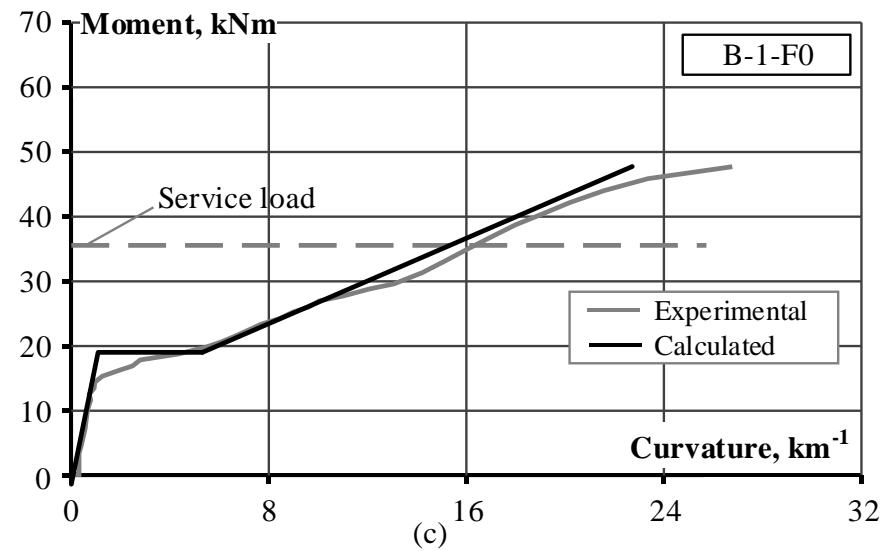

Fig. 3.19. Calculated and experimental moment-curvature diagrams of (a) Series 1, (b) Series 2 and (c) Series 3 beams without fibres 

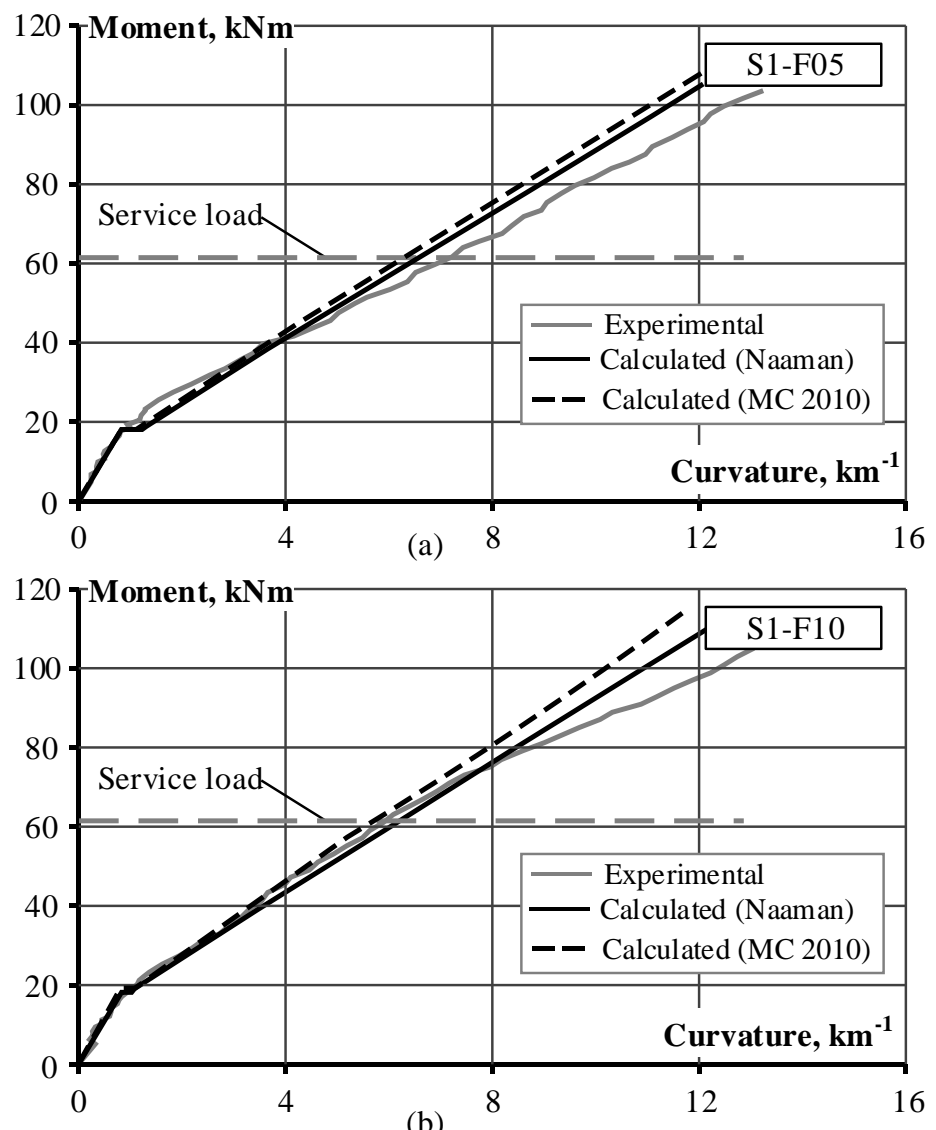

(b)

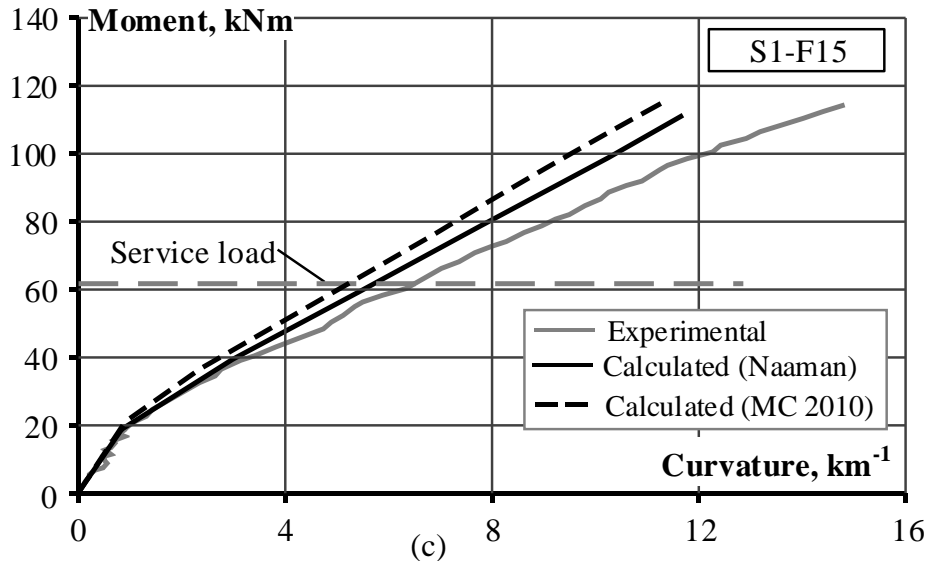

Fig. 3.20 Calculated and experimental moment-curvature diagrams of Series 1 beams (a) S1-F05, (b) S1-F10 and (c) S1-F15 

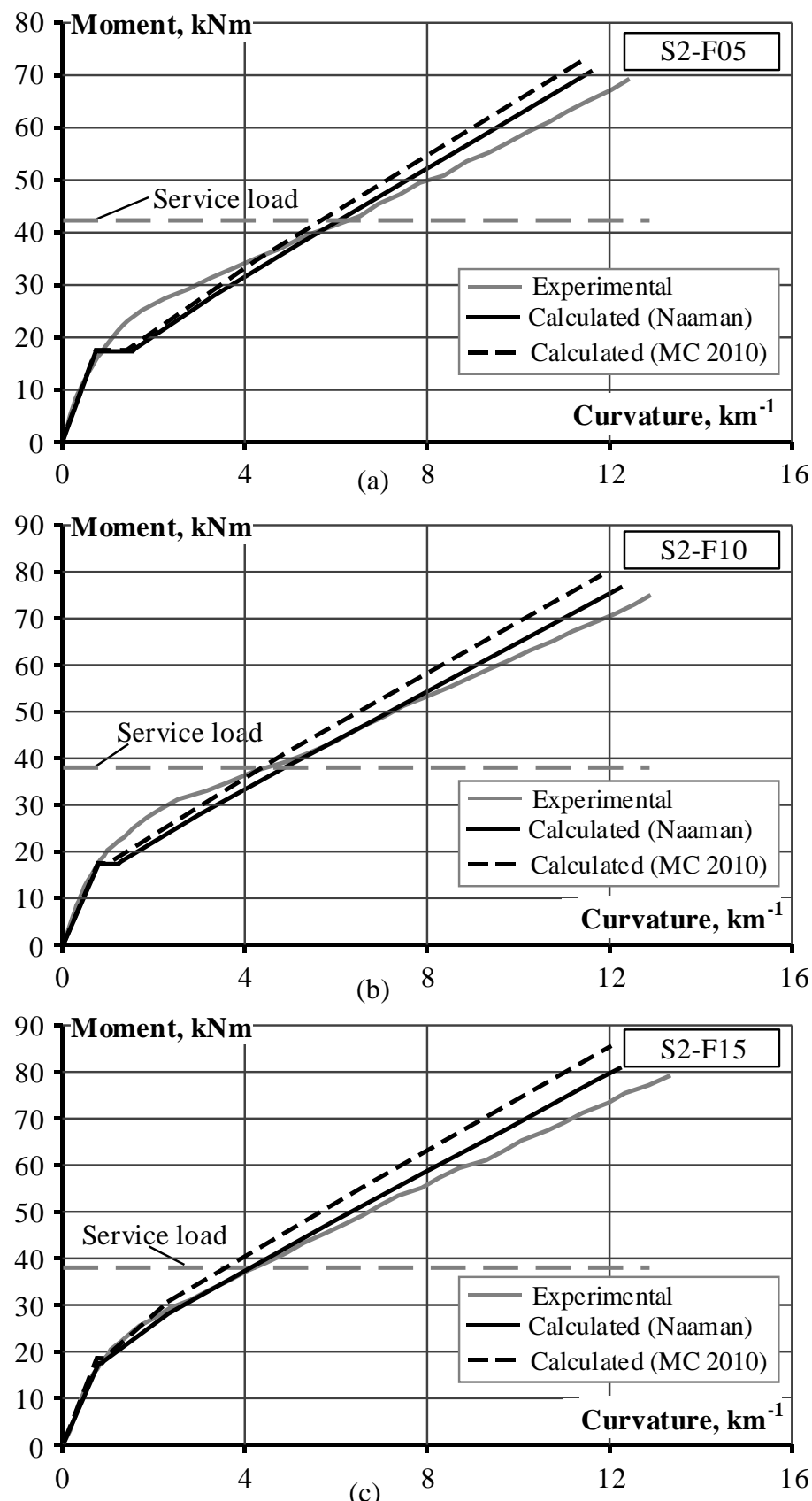

Fig. 3.21 Calculated and experimental moment-curvature diagrams of Series 2 beams (a) S2-F05, (b) S2-F10 and (c) S2-F15 

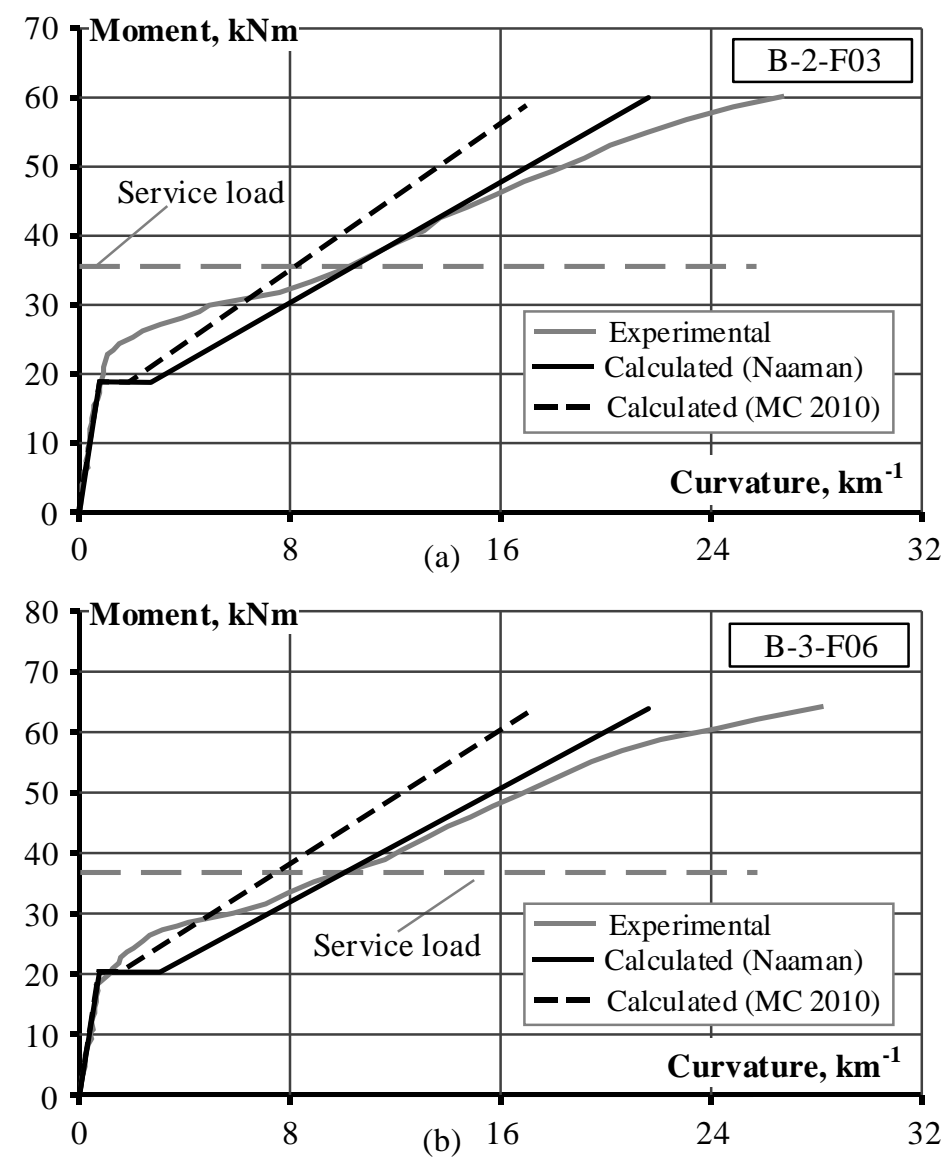

Fig. 3.22 Calculated and experimental moment-curvature diagrams of Series 3 beams (a) B-2-F03 and (b) B-2-F06

Application of the residual strength defined by Model Code 2010 underestimates the results of the flexural response of SFRC elements with bar reinforcement (Figs 3.20, 3.21 and 3.22). At the service load, the average error of the modelled curvatures is $18 \%$ (variation coefficient of the results is equal to $19 \%$ ) and reaches the maximum value of $41 \%$ for the lightly reinforced $p=0.3 \%$ beam B3-F06.

The modelled moment-curvature results of SFRC beams with bar reinforcement have shown that application of the residual strength values calculated by Naaman method gives the average prediction error equal to $7 \%$, with the maximum value of $10 \%$. The variation coefficient of the crack spacing is calculated equal to $9 \%$. 


\subsection{Conclusions of Chapter 3}

The following conclusions of this Chapter may be drawn:

1. The proposed algorithm based on the stress-transfer approach allows to simultaneously model the deflection and cracking response of SFRC beams with bar reinforcement. The essential parameters governing the results of serviceability analysis are the bond-slip and damage zone constitutive laws characterising interaction between reinforcement bars and concrete as well as the residual strength parameters representing the postcracking behaviour of SFRC.

2. The experimental investigation of 11 full-scale flexural elements has shown that the addition of steel fibres leads to the formation of more cracks with smaller spacing. This is mainly related to the residual strength of SFRC, which improves tensile stress transfer in the cracks and leads to the reduction of the bond transfer length. In case of lower fibre volumes the number of main cracks increases only by one or two with respect to $\mathrm{RC}$ beams without fibres. The ramification of cracks is detected in all SFRC beams.

3. The proposed algorithm adequately estimates the serviceability behaviour of reinforced concrete beams without fibres. The modelled curvature and crack spacing fit the experimental results with the prediction errors up to 5 and $7 \%$, respectively.

4. Based on the performance of standard beams, the residual strength defined by Model Code 2010 underestimates the results of the flexural response of steel fibre reinforced concrete elements with bar reinforcement. At the service load, the error of modelled crack spacing results reaches $42 \%$, with the mean value of $15 \%$ and the coefficient of variation equal to $20 \%$. The experimental curvatures are underestimated up to maximum value of $41 \%$ (mean value $18 \%$, coefficient of variation 19\%).

5. The analysis of the average crack spacing and deformation results of SFRC beams reinforced with steel bars has revealed that the residual strength values defined by Naaman assures adequate modelling of the serviceability behaviour. At the service load the modelled curvature results fit the experimental ones with the maximum error of $10 \%$ (mean value reaches $7 \%$, coefficient of variation $-9 \%$ ). The crack spacing prediction error reaches $14 \%$ with the mean value of only $2 \%$ and the coefficient of variation equal to $12 \%$. 



\section{General Conclusions}

1. The proposed inverse algorithm for the determination of the residual strength of SFRC in tension may serve as an alternative to the constitutive modelling methods proposed in the design guidelines. Unlike the standard methods based on the empirical relations and related to the specific geometry of the test specimens, the proposed algorithm is based on general principles of material mechanics. In addition to the mechanical soundness it is more versatile than the traditional approaches as it is not limited to a particular geometry of test specimens and the residual strength can be defined at any load level.

2. Unlike most of the serviceability techniques that are used specifically either for deformation or crack analysis, the algorithm based on the stresstransfer approach allows to simultaneously model the deflection and cracking response of SFRC beams with bar reinforcement. In addition to the residual strength, the constitutive laws characterising bond-slip and damage zone are the basic constitutive parameters governing the results of analysis.

3. The proposed modelling technique based on the stress-transfer approach and the damage zone concept assures adequate modelling of serviceability 
behaviour of flexural RC elements with bar reinforcement. Calculation errors of crack spacing and curvature reach $7 \%$ and $5 \%$, respectively.

4. The residual strength based on the standard flexural tests can assure reliable simulation results of the serviceability behaviour of SFRC members without bars, however it is not capable to secure adequate analysis of SFRC beams with bar reinforcement. The experimental curvatures and crack spacing at the service load are underestimated up to $41 \%$ (mean value $18 \%$ ) and up to $42 \%$ (mean value $15 \%$ ), respectively.

5. The proposed modelling technique based on the stress-transfer approach combined with damage zone concept and the residual strength model by Naaman assures adequate modelling of serviceability behaviour of SFRC beams reinforced with bars. The curvature and crack spacing prediction errors reach $10 \%$ (mean value $7 \%$ ) and $14 \%$ (mean value $2 \%$ ), respectively. 


\section{References}

ACI 544.1R-96. 2002. Report on Fiber Reinforced Concrete (Reapproved 2009), Detroit, MI: Amertican Concrete Institute, $66 \mathrm{p}$.

ASTM C1550-12a. 2012. Standard Test Method for Flexural Toughness of Fiber Reinforced Concrete (Using Centrally Loaded Round Panel), West Conshohocken, PA: ASTM International, $13 \mathrm{p}$.

Aveston, J. \& Kelly, A. 1973. Theory of multiple fracture of fibrous composites. Journal of Materials Science, 8(3), 352-362.

Banholzer, B., Brameshuber, W., \& Jung, W. 2005. Analytical simulation of pull-out tests - the direct problem. Cement and Concrete Composites, 27(1), 93-101.

Banholzer, B., Brameshuber, W., \& Jung, W. 2006. Analytical evaluation of pull-out tests - the inverse problem. Cement and Concrete Composites, 28(6), 564-571.

Barros, J. A., \& Figueiras, J. A. 1999. Flexural behavior of SFRC: testing and modeling. Journal of Materials in Civil Engineering, 11(4), 331-339.

Bažant, Z. P., \& Oh, B. H. 1983. Crack band theory for fracture of concrete. Matériaux et Construction, 16(3), 155-177.

Bencardino, F., Rizzuti, L., Spadea, G., \& Swamy, R. N. 2008. Stress-strain behavior of steel fiber-reinforced concrete in compression. Journal of Materials in Civil Engineering, 20(3), 255-263. 
Bentur, A., \& Mindess, S. 2007. Fibre reinforced cementitious composites, New York, NY: Taylor \& Francis, 603 p.

Bigaj-van Vliet, A. J. 2001. Bond of deformed reinforcing steel bars embedded in steel fiber reinforced concrete - State-of-the-art report. Delft Cluster, 65 p.

Blanco, A., Pujadas, P., de la Fuente, A., Cavalaro, S., \& Aguado, A. 2013. Application of constitutive models in European codes to RC-FRC. Construction and Building Materials, 40, 246-259.

Campione, G. 2008. Simplified flexural response of steel fiber-reinforced concrete beams. Journal of Materials in Civil Engineering, 20(4), 283-293.

Carnovale, D., \& Vecchio, F. J. 2014. Effect of fiber material and loading history on shear behavior of fiber-reinforced concrete. ACI Structural Journal, 111(5), 1235.

Chalioris, C. E. 2013. Steel fibrous RC beams subjected to cyclic deformations under predominant shear. Engineering Structures, 49, 104-118.

CNR-DT204. 2007. Guidelines for design, construction and production control of fiber reinforced concrete structures, Rome: National Research Council of Italy, 59 p.

Cornelissen, H. A. W., Hordijk, D. A., \& Reinhardt, H. W. 1986. Experimental determination of crack softening characteristics of normalweight and lightweight concrete. HERON, 31 (2), 45-56.

DAfStb. 2010. Richtlinie Stahlfaserbeton (Guidelines for Steel Fiber Reinforced concrete), Berlin: Deutscher Ausschuss für Stahlbeton, 45 p.

Darwin, D., Barham, S., Kozul, R., \& Luan, S. 2001. Fracture energy of high-strength concrete. ACI Materials Journal, 98(5), 410-417.

DBV. 2007. DBV-Guide to Good Practice. Steel Fibre Concrete, Berlin: German Society for Concrete and Construction Technology, $79 \mathrm{p}$.

de Montaignac, R., Massicotte, B., \& Charron, J. P. 2012. Design of SFRC structural elements: flexural behaviour prediction. Materials and structures, 45(4), 623-636.

Deluce, J. R., \& Vecchio, F. J. 2013. Cracking Behavior of Steel Fiber-Reinforced Concrete Members Containing Conventional Reinforcement. ACI Structural Journal, 110(3), 481-490.

Deluce, J.R., Lee, S.C., \& Vecchio, F. J. 2014. Crack model for steel fibre reinforced concrete members containing conventional reinforcement. ACI Structural Journal, 111(1), 93-102.

di Prisco, M., Colombo, M., \& Dozio, D. 2013. Fibre- reinforced concrete in fib Model Code 2010: principles, models and test validation. Structural Concrete, 14(4), 342-361.

di Prisco, M., Felicetti, R., \& Plizzari, G. 2004. Fibre-reinforced concrete. RILEM Proceedings of the 6th RILEM Symposium (BEFIB 2004), 101-110.

di Prisco, M., Plizzari, G., \& Vandewalle, L. 2009. Fibre reinforced concrete: new design perspectives. Materials and Structures, 42(9), 1261-1281. 
Dupont, D. 2003. Modelling and Experimental Validation of the Constitutive Law $(\sigma-\varepsilon)$ and Cracking Behaviour of Steel Fibre Reinforced Concrete. Doctoral dissertation, Leuven: Katholieke Universiteit Leuven, 215 p.

Dupont, D., Vandewalle, L., \& De Bonte, F. (2002). Influence of steel fibres on local bond behaviour. Bond in concrete - from research to standards, 783-790.

Elices, M. G. G. V., Guinea, G. V., Gomez, J., \& Planas, J. 2002. The cohesive zone model: advantages, limitations and challenges. Engineering fracture mechanics, 69(2), $137-163$.

EN 14651. 2007. Test method for metallic fibre concrete - measuring the flexural tensile strength (Limit of Proportionality (LOP), residual), Brussels: European Committee for Standardization, $17 \mathrm{p}$.

Ezeldin, A. S., \& Balaguru, P. N. 1992. Normal-and high-strength fiber-reinforced concrete under compression. Journal of Materials in Civil Engineering, 4(4), 415-429.

Ferrara, L., \& Meda, A. 2006. Relationships between fibre distribution, workability and the mechanical properties of SFRC applied to precast roof elements. Materials and Structures, 39(4), 411-420.

Ferrara, L., Bamonte, P., Caverzan, A., Musa, A., \& Sanal, I. 2012. A comprehensive methodology to test the performance of steel fibre reinforced self-compacting concrete (SFR-SCC). Construction and Building Materials, 37, 406-424.

fib (International Federation for Structural Concrete). 2013. Model Code for Concrete Structures 2010, Berlin: Ernst \& Sohn, 402 p.

Fischer, G., \& Li, V.C. 2002. Influence of matrix ductility on tension-stiffening behavior of steel reinforced engineered cementitious composites (ECC). Structural Journal, 99(1), 104-111.

Foster, S. J. 2014. FRC design according to the draft Australian bridge code. Proceedings FRC 2014 Joint ACI-fib International Workshop Fibre Reinforced Concrete: From Design to Structural Applications, 19-31.

Gettu, R. 2008. Fibre Reinforced Concrete: Design and Applications - BEFIB 2008, Bagneux: RILEM Publications S.A.R.L., 1181 p.

Gribniak, V., Cervenka, V., \& Kaklauskas, G. 2013a. Deflection prediction of reinforced concrete beams by design codes and computer simulation. Engineering Structures, 56, 2175-2186.

Gribniak, V., Kaklauskas, G., Kwan, A. K. H., Bacinskas, D., \& Ulbinas, D. 2012. Deriving stress-strain relationships for steel fibre concrete in tension from tests of beams with ordinary reinforcement. Engineering Structures, 42, 387-395.

Gribniak, V., Kaklauskas, G., Torres, L., Daniunas, A., Timinskas, E., \& Gudonis, E. 2013b. Comparative analysis of deformations and tension-stiffening in concrete beams reinforced with GFRP or steel bars and fibers. Composites Part B: Engineering, 50, 158170. 
Grzybowski, M., \& Shah, S. P. 1990. Shrinkage cracking of fiber reinforced concrete. ACI Materials Journal, 87(2), 138-148.

Hannant, D. J. 1978. Fiber Cements and Fiber Concretes, New York, NY: John Wiley \& Sons, $219 \mathrm{p}$.

Hillerborg, A. 1980. Analysis of Fracture by Means of the Fictitious Crack Model, Particularly for Fibre Reinforced Concrete. In International Journal of Cement Composites, 2(4), 177-184.

Hillerborg, A., Modéer, M., \& Petersson, P. E. 1976. Analysis of crack formation and crack growth in concrete by means of fracture mechanics and finite elements. Cement and Concrete Research, 6(6), 773-781.

Hordijk, D. A. 1991. Local approach to fatigue of concrete. Doctoral dissertation, Delft: Delft University of Technology, $210 \mathrm{p}$.

Hsu, L. S., \& Hsu, C. T. 1994. Stress-strain behavior of steel-fiber high-strength concrete under compression. Structural Journal, 91(4), 448-457.

Jakubovskis, R., \& Juknys, M. 2016. Cracking and Deformation Modelling of Tensile RC Members Using Stress Transfer Approach. Science - Future of Lithuania, 8 (5), 499-503.

Jakubovskis R., Kaklauskas G., Gribniak V., Weber A. \& Juknys M. 2014. Serviceability analysis of concrete beams with different arrangements of GFRP bars in the tensile zone. Journal of Composites for Construction, 18(5), 1-10.

Jakubovskis R., Kaklauskas G., Juknys M., \& Gribniak V. 2013. Serviceability analysis of reinforced concrete members based on stress transfer approach. Procedia Engineering. 11th international conference on modern building materials, structures and techniques (MBMST), 57, 450-455.

JCI-S-002. 2003. Method of test for load-displacement curve of fiber-reinforced concrete by use of notched beam, Tokyo: Japan Concrete Institute, $6 \mathrm{p}$.

JCI-S-003, 2007. Method of test for bending moment-curvature curve of fiber-reinforced cementitious composites, Tokyo: Japan Concrete Institute, 7 p.

Johnston, C. D. 2001. Fibre-reinforced cements and concretes. Ottawa, ON: Gordon and Breach Science Publishers, 372 p.

Juknys M. 2017. Tempiamujų gelžbetoninių elementu diskrečiu plyšiu modelio fizikinių parametru eksperimentiniai ir skaitiniai tyrimai. Doctoral dissertation, Vilnius: Technika, $113 \mathrm{p}$.

Kaklauskas, G., Gribniak, V., \& Bacinskas, D. 2011. Inverse technique for deformational analysis of concrete beams with ordinary reinforcement and steel fibers. Procedia Engineering, 14, 1439-1446.

Kanakubo, T. 2006. Tensile characteristics evaluation method for ductile fiber-reinforced cementitious composites. Journal of Advanced Concrete Technology, 4(1), 3-17. 
Khaloo, A. R., \& Kim, N. 1997. Influence of concrete and fiber characteristics on behavior of steel fiber reinforced concrete under direct shear. ACI Materials Journal, 94(6), 592601.

Kooiman, A. G. 2000. Modelling Steel Fibre Reinforced Concrete for Structural Design. Doctoral dissertation, Delft: Delft University of Technology, $171 \mathrm{p}$.

Kullaa, J. 1994. Fibre-reinforced concrete under uniaxial tension. Nordic Concrete Research, 14, 77-90.

Lange-Kornbak, D., \& Karihaloo, B. L. 1998. Design of fiber-reinforced DSP mixes for minimum brittleness. Advanced Cement Based Materials, 7(3), 89-101.

Laranjeira de Oliveira, F. 2010. Design-oriented constitutive model for steel fiber reinforced concrete. Doctoral dissertation, Barcelona: Universitat Politècnica de Catalunya, $200 \mathrm{p}$.

Lee, S. C., Cho, J. Y., \& Vecchio, F. J. 2011. Diverse embedment model for steel fiberreinforced concrete in tension: Model verification. ACI Materials Journal, 108(5), 526535.

Lee, S. C., Cho, J. Y., \& Vecchio, F. J. 2012. Simplified Diverse Embedment Model for SFRC Element in Tension. ACI Materials Journal, 110(4), 403-412.

Li, C. V., \& Fischer, G. 2002. Reinforced ECC - an evolution from materials to structures. FIB Proceedings of the 1st fib Congress, 105-122.

Li, V. C. 1992. Post-crack scaling relations for fiber reinforced cementitious composites, ASCE Journal of Materials in Civil Engineering, 4(1), 41-57.

Li, V. C., Stang, H., \& Krenchel, H. 1993. Micromechanics of crack bridging in fibrereinforced concrete. Materials and Structures, 26(8), 486-494.

Lim, T. Y, Paramasivam, P., \& Lee, S. L. 1987. Analytical Model for Tensile Behaviour of Steel-Fiber Concrete. ACI Materials Journal, 84(4), 286-298.

Löfgren, I., Stang, H., \& Olesen, J. F. 2005. Fracture properties of FRC determined through inverse analysis of wedge splitting and three-point bending tests. Journal of Advanced Concrete Technology, 3(3), 423-434.

Lok, T.S., \& Pei, J.S., 1998. Flexural behavior of steel fiber reinforced concrete. Journal of Materials in Civil Engineering, 10(2), 86-97.

Lok, T. S., \& Xiao, J. R. 1999. Flexural strength assessment of steel fiber reinforced concrete. Journal of Materials in Civil engineering, 11(3), 188-196.

Luccioni, B., Ruano, G., Isla, F., Zerbino, R., \& Giaccio, G. 2012. A simple approach to model SFRC. Construction and Building Materials, 37, 111-124.

Löfgren, I. 2005. Fibre-reinforced concrete for industrial construction - a fracture mechanics approach to material testing and structural analysis. Doctoral dissertation, Göteborg: Chalmers University of Technology, 146 p. 
Mansur, M. A., Chin, M. S., \& Wee, T. H. 1999. Stress-strain relationship of high-strength fiber concrete in compression. Journal of Materials in Civil Engineering, 11(1), 21-29.

Marciukaitis J. G., Salna R., Jonaitis B., \& Valivonis J. 2011. A model for strength and strain analysis of steel fiber reinforced concrete. Journal of civil engineering and management, 17( 1), 137-145.

Markovic, I. 2006. High-performance hybrid-fibre concrete: development and utilisation. Doctoral dissertation, Delft: Delft University of Technology, 211 p.

Michels, J., Christen, R., \& Waldmann, D. 2013. Experimental and numerical investigation on postcracking behavior of steel fiber reinforced concrete. Engineering Fracture Mechanics, 98, 326-349.

Naaman, A. E. 2003a. Engineered steel fibers with optimal properties for reinforcement of cement composites, Journal of Advanced Concrete Technology, 1(3), 241-252.

Naaman, A. E. 2003b. Strain hardening and deflection hardening fiber reinforced cement composites. High Performance Fiber Reinforced Cement Composites 4 (HPFRCC 4), 95113.

Naaman, A. E. 2007. Tensile strain-hardening FRC composites: Historical evolution since the 1960's. Advances in Construction Materials, 181-202.

Naaman, A. E. 2008. High-Performance Construction Materials: Science and Applications, Singapore: World Scientific Publishing, 91-153.

Naaman, A. E., \& Reinhardt, H. W. 2006. Proposed classification of HPFRC composites based on their tensile response. Materials and Structures, 39(5), 547-555.

Naaman, A. E., \& Shah, S. P. 1975. Bond studies of orientated and aligned fibres. RILEM Symposium on Fiber Reinforced Concrete, 171-178.

Naaman, A. E., \& Shah, S. P. 1976. Pullout mechanism in steel fibre reinforced concrete. ASCE Journal, 102(8), 1537-1548.

Naaman, A. E., \& Shah, S. P. 1979. Fracture and Multiple Cracking of Cementitious Composites. Fracture Mechanics Applied to Brittle Materials, 183-201.

Nataraja, M., Dhang, N., \& Gupta, A. 1999. Stress-strain curves for steel-fiber reinforced con-crete under compression. Cement and Concrete Composites, 21, 383-390.

Neville, A. M. 1997. Aggregate Bond and Modulus of Elasticity of Concrete. ACI Materials Journal, 71-74.

NT BUILD 511. 2005. Wedge Splitting Test method (WST): fracture testing of fibre-reinforced concrete (Mode I), Oslo: Nordic Innovation Centre, 6 p.

Pereira, E. N., Barros, J. A., \& Camões, A. 2008. Steel fiber-reinforced self-compacting concrete: experimental research and numerical simulation. Journal of Structural Engineering, 134(8), 1310-1321.

Peterson, P. E. 1980. Fracture energy of concrete: Method of determination. Cement and Concrete Research, 10(1), 79-89. 
Plizzari, G. A., Lundgren, K., \& Balázs, G. L. 2002. Bond and Splitting in Fibre Reinforced Concrete Under Repeated Loading. Bond in Concrete-from research to standards, 221-229.

Prudencio, L., Simon, A., Jones, P., Armelin, H., \& Robins, P. 2006. Prediction of steel fibre reinforced concrete under flexure from an inferred fibre pull-out response. Materials and Structures, 39(6), 601-610.

Qian, S., \& Li, V. C. 2008. Simplified inverse method for determining the tensile properties of strain hardening cementitious composites (SHCC). Journal of Advanced Concrete Technology, 6(2), 353-363.

Reinhardt, H. W., Naaman, A. E. 2007. High Performance Fibre Reinforced Cement Composites (HPFRCC5), Bagneux: RILEM Publications S.A.R.L., 518 p.

RILEM TC 162-TDF. 2001. Test and design methods for steel fibre reinforced concrete. Uni-axial tension test for steel fibre reinforced concrete. Recommendations. Materials and Structures, 34(235), 3 p.

RILEM TC 162-TDF. 2002a. Test and design methods for steel fibre reinforced concrete. Materials and Structures, 35, 579-582.

RILEM TC 162-TDF. 2002b. Test and design methods for steel fibre reinforced concrete: design of steel fibre reinforced concrete using the $\sigma-\mathrm{w}$ method: principles and applications. Materials and Structures, 35, 262-278.

RILEM TC 162-TDF. 2003. Test and design methods for steel fibre reinforced concrete: $\sigma$ - $\varepsilon$-design method. Final recommendations. Materials and Structures, 36(262), 560-567.

Rizzuti, L., \& Bencardino, F. 2014. Effects of fibre volume fraction on the compressive and flexural experimental behavior of SFRC. Contemporary Engineering Sciences, 7, 379-390.

Romualdi, J. P., \& Mandel, J. A. 1964. Tensile strength of concrete affected by uniformly distributed and closely spaced short lengths of wire reinforcement. ACI Journal, 61(6), 657-671.

Rossi, P., \& Chanvillard, G. 2000. Fibre Reinforced Concretes. RILEM Proceedings of the 5th RILEM Symposium (BEFIB 2000), 451-460.

Ruiz, M. F., Muttoni, A., \& Gambarova, P. G. 2007. Analytical modeling of the pre-and postyield behavior of bond in reinforced concrete. Journal of Structural Engineering, 133(10), 1364-1372.

Salem, H., \& Maekawa, K. 1999. Spatially averaged tensile mechanics for cracked concrete and reinforcement under highly inelastic range. Doboku Gakkai Ronbunshu, 1999(613), 277-293.

Salna R. 2008. Dispersinio armavimo ịtaka gelžbetoninių besiju perdangos plokščiu praspaudimui. Doctoral dissertation, Kaunas: Lithuanian Academic Libraries Network (LABT), 146 p. 
Salna R., \& Marciukaitis J. G. 2010. Influence of fiber shape on the strength of steel fiber reinforced concrete. 10th International Conference Modern Building Materials, Structures and Techniques: selected papers, 2, 763-767.

Sokolov A., Kaklauskas G., Jakubovskis R., Juknys M., Kliukas R., Ng P. L., \& Gribniak V. 2016. Experimental investigation of tension stiffening in RC ties. Advances in Material Science and Engineering, 2016, 1-8.

Schnütgen, B., \& Vandewalle, L. 2003. Test and Design methods for Steel fibre reinforced concrete - Background and Experiences. Preface, Bochum: RILEM Publications S.A.R.L., 209 p.

Schönlin, K. 1988. Ermittlung der Orientierung, Menge und Verteilung der Fasern in faserbewehrtem Beton. Beton- und Stahlbetonbau, 83(6), 168-171.

Setkit, M. 2012. Seismic Behaviour of Slender Coupling Beams Constructed With HighPerformance Fibre-Reinforced Concrete. Doctoral dissertation, Ann Arbor, MI: University of Michigan, $261 \mathrm{p}$.

Shah, S. P., \& Rangan, B. V. 1970. Effects of reinforcement on ductility of concrete. ASCE Journal, 96(6), 1167-1184.

Shah, S. P., \& Rangan, B. V. 1971. Fibre reinforced concrete properties. ACI Journal, 68(2), 126-135.

Someh, A. K., \& Saeki, N. 1994. Prediction for the stress-strain curve of steel fiber reinforced concrete. Proceedings of Japan Concrete Institute, 18, 1149-1154.

Sorelli, L., Meda, A., \& Plizzari, G. 2006. Steel fiber concrete slabs on ground: A structural matter. ACI Structural Journal, 103(4), 551-558.

Soroushian, P., \& Lee, C. D. 1990. Distribution and Orientation of Fibers in Steel Fiber Reinforced Concrete. ACI Materials Journal, 433-439.

Sousa, J. L. A. O, \& Gettu, R. 2006. Determining the tensile stress-crack opening curve of concrete by inverse analysis. Journal of Engineering Mechanics, 132(2), 141-148.

SS 812310. 2014. Fibre Concrete - Design of Fibre Concrete Structures, Stockholm: Swedish Standard Institute, $48 \mathrm{p}$.

Stang, H. \& Li, V. C. 2004. Classification of fiber reinforced cementitious materials for structural applications. 6th RILEM Symposium on Fiber-Reinforced Concretes (BEFIB 2004), 197-218.

Stang, H., \& Aarre, T. 1992. Evaluation of crack width in FRC with conventional reinforcement. Cement and Concrete Composites, 14(2), 143-154.

Stroeven, P. 1978. Morphometry of fibre reinforced cementitious materials - Part 1: Efficiency and spacing in idealized structures. Materials and Structures, 11(61), 31-37.

Susetyo, J., Gauvreau, P., \& Vecchio, F. J. 2011. Effectiveness of Steel Fiber as Minimum Shear Reinforcement. ACI Structural Journal, 108(4), 488-496. 
Swamy, R. N., Mangat, P. S. \& Rao, C. V. S. K., 1974. The Mechanics of Fiber Reinforcement of Cement Matrices. ACI Special Publication, 44, 1-28.

Thomas, J., \& Ramaswamy, A. 2007. Mechanical Properties of Steel Fiber-Reinforced Concrete. Journal of Materials in Civil Engineering, 19(5), 385-392.

Tiberti, G., Minelli, F., Plizzari, G. A., \& Vecchio, F.J. 2014. Influence of concrete strength on crack development in SFRC members. Cement and Concrete Composites, 45 , $176-185$.

Van Mier, J. G. M. 1997. Fracture processes of concrete: assessment of material parameters for fracture models, Boca Raton, FL: CRC Press, $448 \mathrm{p}$.

Van Mier, J. G. M., \& van Vliet, M. R. A. 2002. Uniaxial tension test for the determination of fracture parameters of concrete: state of the art. Engineering Fracture Mechanics, 69, 235-247.

Van Vliet, M. R. A., \& van Mier, J. G. M. 1999. Effect of strain gradients on the size effect of concrete in uniaxial tension. International Journal of Fracture, 95, 195-219.

Vandewalle, L. 2000. Cracking behaviour of concrete beams reinforced with a combination of ordinary reinforcement and steel fibers. Materials and Structures, 33(227), 164170.

Vandewalle, L., 1999. Influence of Tensile Strength of Steel Fibre on Toughness of High Strength Concrete, Proceedings of Third International Workshop on High-Performance Cement Composites, 331-337.

Voo, J., \& Foster, D. 2003. Variable Engagement Model for Fibre Reinforced Concrete in Tension. Advanced Materials for Construction of Bridges, Buildings, and Other Structures III, 1-10.

Walraven, J. C. 1981. Fundamental analysis of aggregate interlock. Journal of the Structural Division, 107(11), 2245-2270.

Yoo, D. Y., Yoon, Y. S., \& Banthia, N. 2015. Predicting the post-cracking behavior of normal-and high-strength steel-fiber-reinforced concrete beams. Construction and Building Materials, 93, 477-485. 



\section{List of Scientific Publications by the Author on the Topic of the Dissertation}

\section{Papers in Scientific Journals}

Meškènas, A., Gribniak, V., Kaklauskas, G., Sokolov, A., Gudonis, E., Rimkus, A. 2017. Experimental investigation of cracking behaviour of concrete beams reinforced with steel fibres produced in Lithuania. The Baltic Journal of Road and Bridge Engineering, Vilnius: Technika. 12(2), 82-87. [Clarivate Analytics Web of Science, IF: 0.698].

Gribniak, V.; Kaklauskas, G.; Juozapaitis, A.; Kliukas, R.; Meškènas, A. 2017. Efficient technique for constitutive analysis of reinforced concrete flexural members. Inverse problems in science and engineering. Oxon: Taylor \& Francis Ltd. ISSN: 1741-5977, eISSN: 1741-5985. 25(1), 27-40. [Clarivate Analytics Web of Science, IF: 1.033].

Meškènas, A.; Gribniak, V.; Kaklauskas, G.; Arnautov, A. K.; Rimkus, A. 2014a. Simplified technique for constitutive analysis of SFRC. Journal of civil engineering and management. Vilnius: Technika. ISSN: 1392-3730. 20(3), 446-453. [Clarivate Analytics Web of Science, IF: 1.070].

Meškènas, A.; Kaklauskas, G.; Daniūnas, A.; Bačinskas, D.; Jakubovskis, R.; Gribniak, S.; Gelažius, V. 2014b. Determination of the stress-crack opening relationship of SFRC by an inverse analysis. Mechanics of composite materials. New York: Springer US. ISSN: 0191-5665. 49(6), 685-690. [Clarivate Analytics Web of Science, IF: 0.473]. 
Kaklauskas, G.; Gribniak, V.; Meškènas, A.; Bačinskas, D.; Juozapaitis, A.; Sokolov, A.; Ulbinas, D. 2014. Experimental investigation of the deformation behavior of SFRC beams with an ordinary reinforcement. Mechanics of composite materials. New York: Springer US. ISSN: 0191-5665. 50(4), 417-426. [Clarivate Analytics Web of Science, IF: 0.473].

Meškènas, A.; Rimkus, A. 2013. Lenkiamųjų plieno plaušu armuotų betoninių elementų liekamojo stiprio nustatymas. Mokslas - Lietuvos ateitis = Science - future of Lithuania: Statyba, transportas, aviacines technologijos $=$ Civil and transport engineering, aviation technologies. Vilnius: Technika. ISSN: 2029-2341. 5(5), 487-491.

\section{Publications in Conference Proceedings}

Meškėnas, A.; Gelažius, V.; Kaklauskas, G.; Gribniak, V.; Rimkus, A. 2013a. A new technique for constitutive modeling of SFRC. Procedia Engineering. 11th international conference on modern building materials, structures and techniques (MBMST). Amsterdam: Elsevier Science Ltd. ISSN: 1877-7058. 57, 762-766. [ISI Proceedings].

Kaklauskas, G., Gribniak, V., Meškènas, A., Rimkus, A., Kaklauskas, A., Kupliauskas, R. 2013. Determination of the residual stress-crack opening relationship of SFRC flexural members. AIP Conference proceedings. 11th International Conference on Numerical Analysis and Applied Mathematics 2013 (ICNAAM 2013). Melville: AIP Publishing. ISSN 0094-243X. 2151-2154. [ISI Proceedings].

Gribniak, V.; Holschemacher, K.; Kaklauskas, G.; Bačinskas, D.; Ulbinas, D.; Sokolov, A.; Meškènas, A. 2011. Experimental analysis of reinforced fibre concrete beams. Mechanika-2011: proceedings of the 16th international conference. Kaunas: Technologija. ISSN: 1822-2951.93-97. [ISI Proceedings].

Rimkus, A.; Meškènas, A. 2013a. Dispersiškai armuoto tempiamojo betono liekamųjų įtempių nustatymas taikant atvirkštinio uždavinio sprendimą. 16-oji Lietuvos jaunuju mokslininku konferencija „Mokslas - Lietuvos ateitis” 2013 metu temine konferencija „Statyba“. Vilnius: Technika. ISSN: 2029-7149. ISBN: 9786094575365. 1-5.

Rimkus, A.; Meškènas, A. 2013b. Dispersiškai armuotų lenkiamųjų betoninių elementų liekamujų įtempių ir plyšio pločio nustatymas. 16-oji Lietuvos jaunujų mokslininku konferencija ,,Mokslas - Lietuvos ateitis” 2013 metu temine konferencija ,, Statyba “. Vilnius: Technika. ISSN: 2029-7149. ISBN: 9786094575365. 1-5.

Meškėnas, A.; Gelažius, V.; Gribniak, V.; Kaklauskas, G. 2013b. Inverse analysis technique for determination of residual stress-crack opening relationship of SFRC. 7th International Conference FIBRE CONCRETE 2013 12-13 September, Prague, Czech Republic, 2013: proceedings. Prague: Czech Technical University in Prague. ISBN: 9788001052389. 1-6.

Meškėnas, A.; Gelažius, V. 2012. SFRC stress-crack opening relationship prediction by the inverse analysis. 15-osios Lietuvos jaunuju mokslininku konferencijos, „Mokslas - Lietuvos ateitis” teminès konferencijos „Statyba“. Vilnius: Technika. ISSN: 2029-7149. ISBN: 9786094572159. 1-4. 
Meškėnas, A.; Ulbinas, D. 2011. Discrete crack model of steel fibre reinforced concrete members subjected to tension. 14-osios Lietuvos jaunuju mokslininku konferencijos „Mokslas - Lietuvos ateitis” 2011 metu teminés konferencijos „Statyba“. Vilnius: Technika. ISSN: 2029-7149. ISBN: 978955289296. 1-7. 



\section{Summary in Lithuanian}

\section{Ivadas \\ Problemos formulavimas}

Plieno plaušu armuotas betonas yra kompozitinè medžiaga, armuota naudojant chaotiškai išsidèsčiusị plaušą. Toks betono stiprinimo būdas naudojamas statinių konstrukcijoms, kuriose vyrauja lenkimo apkrovos, reikalingas didelis ilgaamžiškumas bei atsparumas smūgiams. Vis dèlto, plieno plaušu armuoto betono taikymas yra ribotas, nes nèra visuotinai priimtų dispersiškai armuoto betono konstrukcijų projektavimo normų.

Tam tikroms konstrukcijoms plieno plaušas yra naudojamas kaip vienintelis armavimo būdas, tačiau dažniausiai dispersinis armavimas taikomas kartu su ịprastu armavimu plieno strypais. Plieno plaušu armuoto tempiamojo betono medžiagų modeliai, kurie ịprastai nustatomi standartiniais bandymais, yra tinkami dispersiškai armuotų konstrukcijų elgsenos modeliavimui. Tačiau taikant tokius modelius konstrukciju su strypine armatūra tinkamumo ribinio būvio analizei, gaunamos didelès paklaidos. Šiame darbe atliekama plieno plaušu armuoto betono liekamojo stiprio ir plaušu bei strypine armatūra armuotų lenkiamųjų betoninių konstrukcijų ribinio būvio analizè.

\section{Darbo aktualumas}

Plieno plaušu armuotas betonas yra vis dažniau taikomas pastatų ir transporto statinių konstrukcijose. Norint tinkamai suprojektuoti ir pagaminti armuoto betono konstrukcijas, būtina išanalizuoti jų elgseną ir užtikrinti patikimus medžiagų mechaninių savybių nustatymo būdus. Iki šios dienos nèra pasiūlyta universalaus metodo dispersiškai armuotų 
konstrukcijų pleišèjimo ir deformacijų analizei. Skaičiavimo metoduose, ypač inžineriniuose, taikomi supaprastinti medžiagų modeliai, kurie neatspindi sudètingos jų elgsenos. Adekvatus dispersiškai armuoto tempiamojo betono liekamojo stiprio ịvertinimas bei armatūros strypų ir betono sąveikos modeliavimas leidžia tinkamai ịvertinti dispersiškai armuoto betono konstrukcijų pleišèjimą ir deformacijas.

Remiantis plieno plaušu armuoto betono medžiagų modelių analizės rezultatais, pasiūlytas dispersiškai armuotų lenkiamujų elementų su strypine armatūra deformacijų ir pleišèjimo modeliavimo metodas. Deformacijų ir pleišějimo analizei atlikta eksperimentinių tyrimų programa ir analitiniai skaičiavimai.

\section{Tyrimo objektas}

Darbe nagrinèjama plieno plaušu armuotų gelžbetoninių lenkiamųų elementų veikiamų trumpalaike statine apkrova deformacijų ir pleišejimo elgsena.

\section{Darbo tikslas}

Disertacinio darbo tikslas yra pasiūlyti skaitinị-analitinị plieno plaušu armuotų lenkiamuju elementų su strypine armatūra deformacijų ir pleišèjimo modeliavimo metodą.

\section{Darbo uždaviniai}

Darbo tikslui pasiekti sprendžiami šie uždaviniai:

1. Išanalizuoti plieno plaušu armuoto tempiamojo betono medžiagų modelius.

2. Atlikti dispersiškai armuotų standartinio dydžio lenkiamųų elementų liekamojo stiprio nustatymo eksperimentinius tyrimus.

3. Pasiūlyti liekamojo stiprio modeliavimo metodiką, taikant standartinio dydžio eksperimentinių sijų deformacijų rezultatus.

4. Palyginti skirtingų liekamojo stiprio nustatymo metodų adekvatumą.

5. Taikant eksperimentinius tyrimus nustatyti dispersiškai armuotų betoninių sijų su strypine armatūra deformacijų ir pleišejimo elgseną.

6. Sukurti dispersiškai armuotų lenkiamųų betoninių elementų deformacijų ir pleišejimo analizès algoritmą, paremtą įtempių perdavimo koncepcija.

7. Lyginant eksperimentinius ir sumodeliuotus pleišèjimo ir deformacijų rezultatus, atlikti pasiūlyto modelio adekvatumo analizę.

\section{Tyrimų metodika}

Disertacinio darbo tikslui pasiekti taikomi teoriniai, skaitiniai ir eksperimentiniai metodai. Tempiamojo dispersiškai armuoto betono liekamojo stiprio bei lenkiamujų plieno plaušu armuotų gelžbetoninių elementų pleišejimo ir deformacijų analizei buvo atlikti eksperi- 
mentiniai tyrimai. Kuriant deformacijų ir pleišèjimo skaičiavimo algoritmą, taikyti skaitiniai ir analiziniai modeliavimo metodai. Apskaičiuotų ir eksperimentinių rezultatų adekvatumui įvertinti taikomas baigtinių elementų metodas.

\section{Mokslinis naujumas}

1. Sukurtas naujas plieno plaušu armuotų betoninių elementų su strypine armatūra deformacijų ir pleišejjimo skaičiavimo metodas, paremtas ịtempių perdavimo algoritmu.

2. Kaip alternatyva praktikoje taikomiems fizikinio modeliavimo metodams, pasiūlytas naujas tempiamojo plieno plaušu armuoto betono liekamųų įtempių nustatymo būdas.

3. Gauti nauji trumpalaike apkrova veikiamų plieno plaušu ir strypais armuotų sijų eksperimentinių tyrimų rezultatai, ịvertinantys lenkiamųjų elementų deformacijas ir pleišejjimą.

\section{Darbo rezultatų praktinè reikšmè}

Disertacijoje pasiūlytas plieno plaušu ir strypais armuotų gelžbetoninių elementų deformacijų ir pleišèjimo modeliavimo metodas, paremtas įtempių perdavimo (diskretaus pleišèjimo) koncepcija. Skirtingai nuo daugelio tinkamumo ribinio būvio analizès algoritmų, šiuo metodu galima adekvačiai modeliuoti konstrukcijos deformacijas, plyšių vystymąsi, ivvertinant dispersiškai armuoto betono liekamaji stiprị, strypinès armatūros ir betono sukibimo bei pažeidimo zonos reiškinius. Pasiūlytas įtempių perdavimo algoritmas gali būti universaliai taikomas įvairių rūšių betonų (ịprastam, didelio stiprio) ir skirtingų tipų armatūrų (plieno, kompozitinès) analizei.

\section{Ginamieji teiginiai}

1. Autoriaus pasiūlytas dispersiškai armuoto supleišèjusio betono elgsenos modeliavimo metodas adekvačiai modeliuoja dispersiškai armuoto betono liekamaji stiprį.

2. Dispersiškai armuoto tempiamojo betono liekamasis stipris, nustatytas taikant standartinius eksperimentinius metodus, nèra tinkamas adekvačiai modeliuoti plieno plaušu armuotų gelžbetoninių sijų tinkamumo ribinio būvio elgseną.

3. Sukurtas naujas plieno plaušu armuotų gelžbetoninių elementų deformacijų ir pleišèjimo skaičiavimo metodas paremtas įtempių perdavimo (diskretaus pleišejimo) algoritmu.

\section{Darbo rezultatų aprobavimas}

Disertacijos tema paskelbta 14 mokslinių publikacijų, iš kurių 5 - žurnaluose turinčiuose cituojamumo rodiklį, o 3 - konferencijų rinkiniuose, referuojamuose Clarivate Analytics 
Web of Science duomenų bazèje. Disertacijos autorius darbo rezultatus paskelbè 9 pranešimuose 7 mokslinėse konferencijose:

- 11-oji tarptautinè konferencija „Numerical Analysis and Applied Mathematics“, Rodas, Graikija, 2013.

- 7-oji tarptautinè konferencija „Fibre Concrete 2013“, Praha, Čekijos respublika, 2013.

- 16-oji Lietuvos jaunujų mokslininkų konferencija Mokslas - Lietuvos ateitis, Vilnius, Lietuva, 2013.

- 11-oji tarptautine konferencija „Modern Building Materials, Struc-tures and Techniques“, Vilnius, Lietuva, 2013.

- 15-oji Lietuvos jaunujų mokslininkų konferencija Mokslas - Lietuvos ateitis, Vilnius, Lietuva, 2012.

- 17-oji tarptautinè konferencija „Mechanics of Composite Materials“, Ryga, Latvija, 2012.

- 14-oji Lietuvos jaunujų mokslininkų konferencija Mokslas - Lietuvos ateitis, Vilnius, Lietuva, 2011.

\section{Disertacijos struktūra}

Disertaciją sudaro ịvadas, 3 skyriai, bendrosios išvados, autoriaus mokslinių publikacijų disertacijos tema sąrašas (14 publikacijų), santrauka lietuvių kalba ir 3 priedai.

Disertacijos apimtis su santrauka - 120 puslapių. Tekste panaudoti 67 paveikslai, 12 lentelių ir 133 literatūros šaltinių.

\section{Padéka}

Disertacinio darbo autorius dèkoja mokslinio darbo vadovui dr. Dariui Bačinskui už patarimus ir pagalbą rengiant disertaciją.

Už vertingas mokslines j̨žvalgas disertacinio darbo tema autorius dèkoja prof. habil. dr. Gintariui Kaklauskui.

Autorius taip pat dèkoja dr. Viktor Gribniak už mokslines diskusijas bei motyvaciją rengiant disertaciją.

Už patarimus, palaikymą ir pagalbą autorius dèkoja Vilniaus Gedimino technikos universiteto Tiltų ir specialiujų statinių katedros darbuotojams bei doktorantams. Autorius ypatingai dèkingas dr. Pui Lam NG už vertingas įžvalgas rengiant disertaciją, dr. Aleksandr Sokolov ir dr. Eugenijui Gudoniui bei visam Statybinių konstrukcijų ir geotechnikos laboratorijos kolektyvui už pagalbą atliekant eksperimentinius tyrimus.

Disertacijos autorius dèkoja prof. dr. Joaquim Antonio Oliveira Barros už pagalbą ir mokslines įžvalgas mokslinès stažuotès Portugalijoje metu.

Autorius taip pat dèkingas Lietuvos mokslo tarybai už finansinę paramą mokslinės stažuotès metu.

Už begalinį rūpestį, palaikymą, kantrybę ir meilę autorius nuoširdžiai dèkoja savo mamai Ritai. 


\section{Plieno plaušu armuoto betono analizè ir modeliavimas}

Pirmajame disertacijos skyriuje pateikiama plieno plaušu armuoto betono raidos, klasifikacijos bei medžiagos modeliavimo metodų literatūros šaltinių apžvalga. Aptariamos pagrindinès charakteristikos ir veiksniai, lemiantys plieno plaušu armuoto betono savybes.

Skirtingai nuo įprastojo, dispersiškai armuoto betono mechaninès elgsenos aprašymui nepakanka nustatyti tik gniuždomojo stiprio. Lemiama charakteristika šiuo atveju yra tempiamojo betono liekamojo stiprio reikšmè. Liekamasis stipris apibūdina supleišèjusio elemento elgseną ir nusako įtempius plyšyje, kuriuos plyši varžantis plieno plaušas perduoda betonui. Supleišejusio tempiamojo dispersiškai armuoto betono tiksliam mechaninès elgsenos aprašymui nepakanka žinoti apytikslių ịtempių plyšyje reikšmių. Būtina nustatyti liekamujų ịtempių dydị bet kuriuo plyšio vèrimosi momentu.

Plieno plaušu armuoto tempiamojo betono medžiagų modeliai dažniausiai nustatomi remiantis eksperimentiniais lenkiamųjų prizmių rezultatais. Literatūroje randama keletas skirtingų standartinių bandymų bei empirinių metodų, lemiančių pakankamai prieštaringus supleišèjusio plieno plaušu armuoto betono liekamojo stiprio rezultatus.

Adekvatus liekamojo stiprio prognozavimas yra vienas sudėtingiausių uždavinių dispersiškai armuoto betono mechanikos teorijoje. Pagrindinès to priežastys - plaušo ir betono parametrų kaita, skirtingi dispersinio armavimo tipai ir formos ir dèl to kintantys plaušo ir betono sukibimo parametrai. Dèl chaotiško plaušo išsibarstymo elemente bei sudètingos betono ir plaušo sąveikos, iki šiol nèra pasiūlyta patikimo dispersiškai armuoto betono elgseną aprašančio modelio (di Prisco et. al. 2009, Jansson 2011, Vandewalle 2000).

Kaip alternatyva praktikoje taikomiems inžineriniams metodams, itempių perdavimo (diskretaus pleišèjimo) algoritmu galima modeliuoti plieno plaušu bei strypine armatūra armuotų lenkiamųjų betoninių konstrukcijų tinkamumo ribinị būvị. Adekvačiai deformacijų ir pleišèjimo analizei lemiamos ịtakos turi tinkamas liekamojo stiprio, armatūros ir betono sukibimo bei pažeidimo zonos modelių parametrų nustatymas.

\section{Plieno plaušu armuoto betono liekamojo stiprio analizè}

Antrajame disertacijos skyriuje nagrinëjamas dispersiškai armuoto tempiamojo betono medžiagos modelis, charakterizuojamas liekamuoju stipriu. Aprašomi atlikti dispersiškai armuotų standartinio dydžio lenkiamųjų elementų liekamojo stiprio nustatymo eksperimentiniai tyrimai. Skyriuje aprašoma autoriaus pasiūlyti liekamojo stiprio modeliavimo metodika, paremta standartinio dydžio eksperimentinių sijų rezultatais. Palyginamajai analizei pasirenkami skirtingi literatūroje aprašomi liekamojo stiprio nustatymo empiriniai ir eksperimentiniai metodai.

Plieno plaušu armuoto tempiamojo betono liekamojo stiprio nustatymui atlikta eksperimentinè programa, kurią sudaro 48 standartinio dydžio lenkiamieji elementai, apkrauti viena arba dviem koncentruotomis apkrovomis. Pagamintos 5 serijos sijų su skirtingomis betono charakteristikomis ir plieno plaušo kiekiu elemento tūryje. Bandymai atlikti taikant EN14651 (2007) ir DAfStb-Richtlinie (2010) rekomendacijose aprašytas bandinių geometrijos ir apkrovimo sąlygas (S2.1 pav.). Eksperimentinès apkrovos ir plyšio pločio bei 
apkrovos ir ịlinkių priklausomybès, gautos apkraunant sijas viena ir dviem koncentruotomis apkrovomis, pateiktos atitinkamai S2.2 ir S2.3 paveiksluose. Liekamuju įtempių nustatymui taip pat pasirinkta supaprastinta Naaman (Naaman 2003) analitinè išraiška. Vidutinių liekamojo stiprio reikšmių palyginimas pateiktas S2.1 lentelëje.

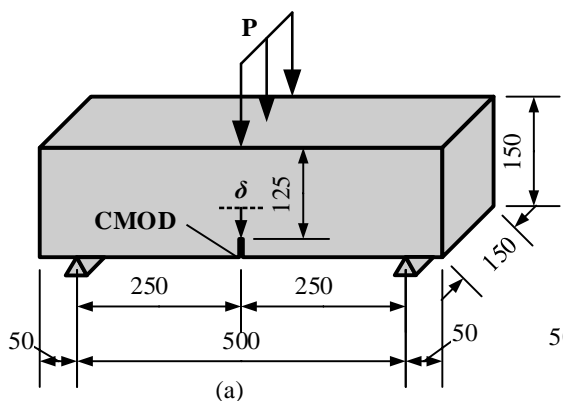

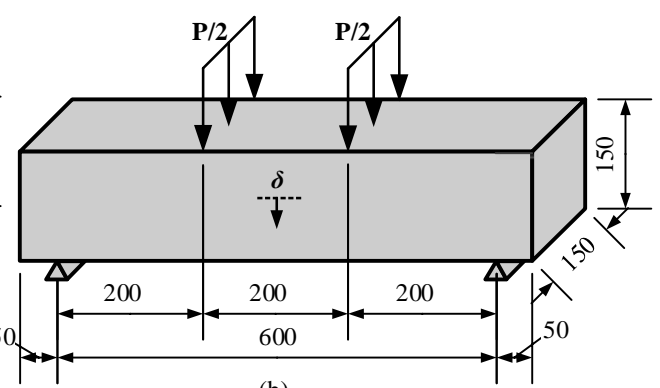

(b)

S2.1 pav. Lenkimo bandymo schema pagal (a) EN14651 ir (b) DAfStb-Richtlinie rekomendacijas
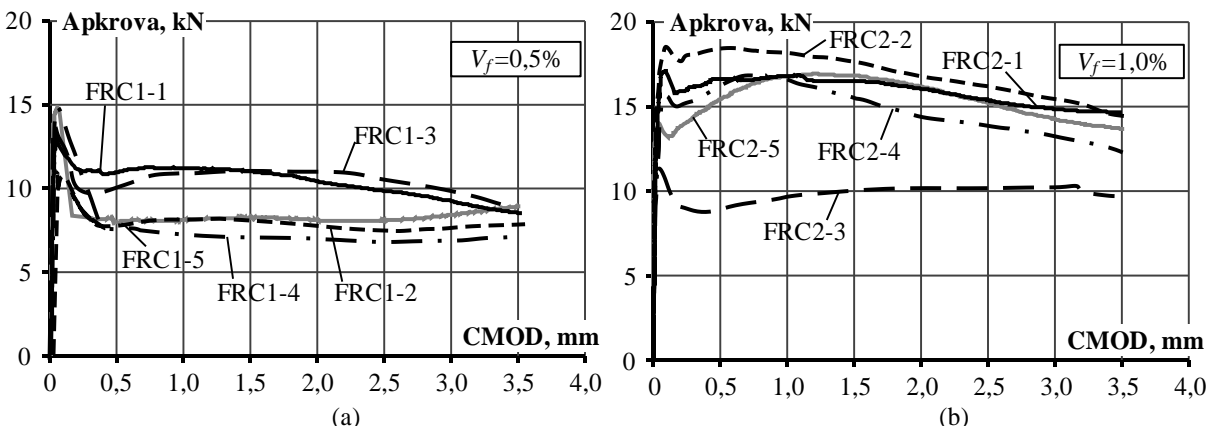

S2.2 pav. Eksperimentinių (a) FRC1 ir (b) FRC2 serijų sijų apkrovos ir plyšio pločio priklausomybès
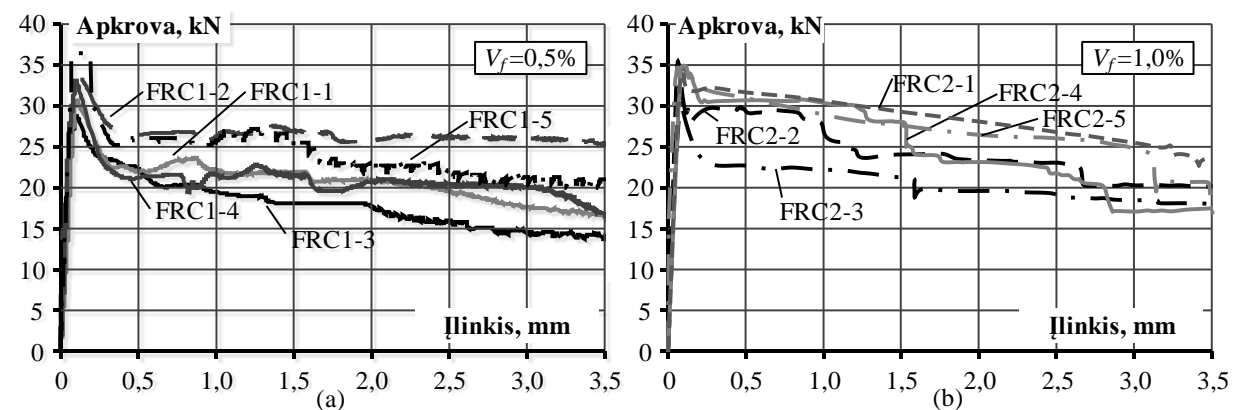

S2.3 pav. Eksperimentinių (a) FRC1 ir (b) FRC2 serijų sijų apkrovos ir įlinkio priklausomybès 
S2.1 lentelè. Vidutinio liekamojo stiprio reikšmès

\begin{tabular}{|c|c|c|c|c|c|c|c|}
\hline \multirow{2}{*}{$\begin{array}{c}\text { Siju } \\
\text { serijos }\end{array}$} & \multicolumn{2}{|c|}{ Rilem } & \multicolumn{2}{c|}{ Model Code 2010 } & \multicolumn{2}{c|}{ DAfStb-Richtlinie } & Naaman \\
\cline { 2 - 8 } & $\boldsymbol{\sigma}_{\boldsymbol{f r} \mathbf{1}, \mathbf{M P a}}$ & $\boldsymbol{\sigma}_{\boldsymbol{f r} \mathbf{4}, \mathbf{M P a}}$ & $\begin{array}{c}\boldsymbol{\sigma}_{\boldsymbol{f r} \mathbf{1},}, \\
\mathbf{M P a}\end{array}$ & $\begin{array}{c}\boldsymbol{\sigma}_{\boldsymbol{f r} \mathbf{3} \mathbf{3}}, \\
\mathbf{M P a}\end{array}$ & $\boldsymbol{\sigma}_{\boldsymbol{f r} \mathbf{r} \mathbf{1}, \mathbf{M P a}}$ & $\boldsymbol{\sigma}_{\boldsymbol{f r} \mathbf{4}, \mathbf{M P a}}$ & $\boldsymbol{\sigma}_{\boldsymbol{f r} \boldsymbol{r}, \mathbf{M P a}}$ \\
\hline FRC1 & 1,28 & 0,94 & 1,28 & 0,78 & 1,68 & 0,81 & 0,60 \\
\hline FRC2 & 2,20 & 1,51 & 2,20 & 1,28 & 2,20 & 0,83 & 1,08 \\
\hline FRC3 & 2,93 & 1,49 & 2,93 & 1,06 & 2,40 & 0,99 & 0,80 \\
\hline FRC4 & 0,96 & 0,53 & 0,96 & 0,50 & 1,45 & 0,62 & 0,41 \\
\hline FRC5 & 2,13 & 1,62 & 2,13 & 1,53 & 2,11 & 1,07 & 0,80 \\
\hline
\end{tabular}

Remiantis medžiagų mechanikos principais bei eksperimentiniais viena koncentruota apkrova lenkiamų bandymų rezultatais, pasiūlytas, plieno plaušu armuoto betono liekamojo stiprio nustatymo metodas. Šis algoritmas pagrịstas ašinių jègų ir momentų pusiausvyros lygčių sprendimu. Lyginant su tradiciniais metodais, pasiūlytas algoritmas leidžia nustatyti liekamajj stiprį bet kurioje apkrovimo (pleišejjimo ar deformacijų) stadijoje. Siūlomas metodas gali būti pritaikytas įvairios geometrijos bei dydžio elementų analizei. Gauti skaičiavimų rezultatai serijų FRC1 ir FRC2 sijoms pateikti S2.4 paveiksle.
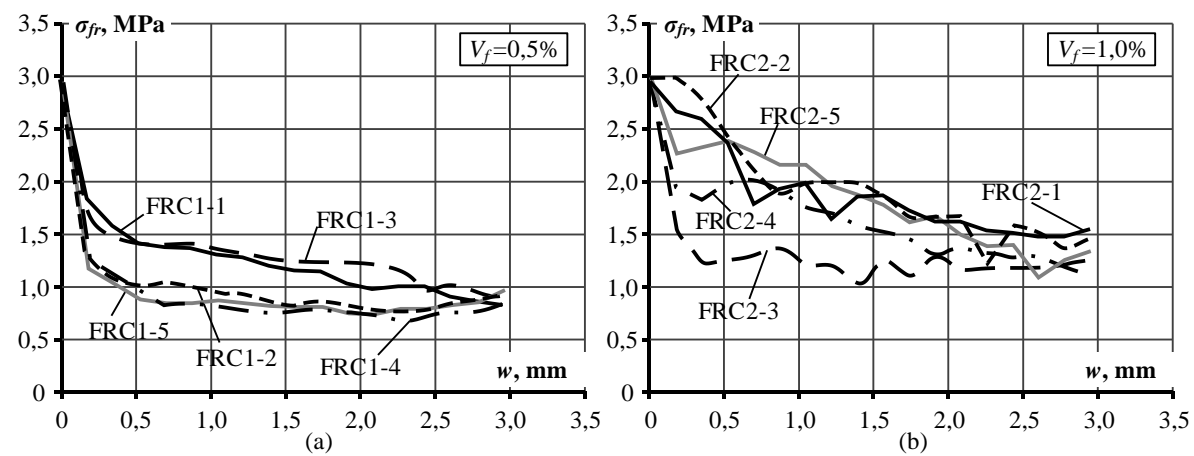

S2.4 pav. Siūlomu metodu gautos (a) FRC1 ir (b) FRC2 serijų sijų liekamojo stiprio ir plyšio pločio priklausomybès

Taikant netiesinės analizès baigtinių elementų programą ATENA, palygintas skirtingų liekamojo stiprio nustatymo metodų adekvatumas, modeliuojant dispersiškai armuotų betoninių (be strypinès armatūros) ir gelžbetoninių elementų elgseną (S2.5 ir S2.6 pav.). Sijų be strypinès armatūros deformacijų analizei taikomos tempiamojo betono itempių ir deformacijų diagramos su liekamųų įtempių reikšmėmis, apskaičiuotomis pagal RILEM TC 162-TDF ir DAfStb-Richtlinie metodus, bei liekamųjų įtempių ir plyšio pločio priklausomybès, nustatytos autoriaus siūlomu algoritmu, Model Code 2010 metodu bei Namman empirine išraiška. Siekiant išvengti modeliuojamų rezultatų paklaidų dèl baigtinių elementų dydžio ịtakos, plieno plaušu armuotų sijų su strypine armatūra analizei naudojamos tik liekamujų ịtempių ir plyšio pločio priklausomybès. 

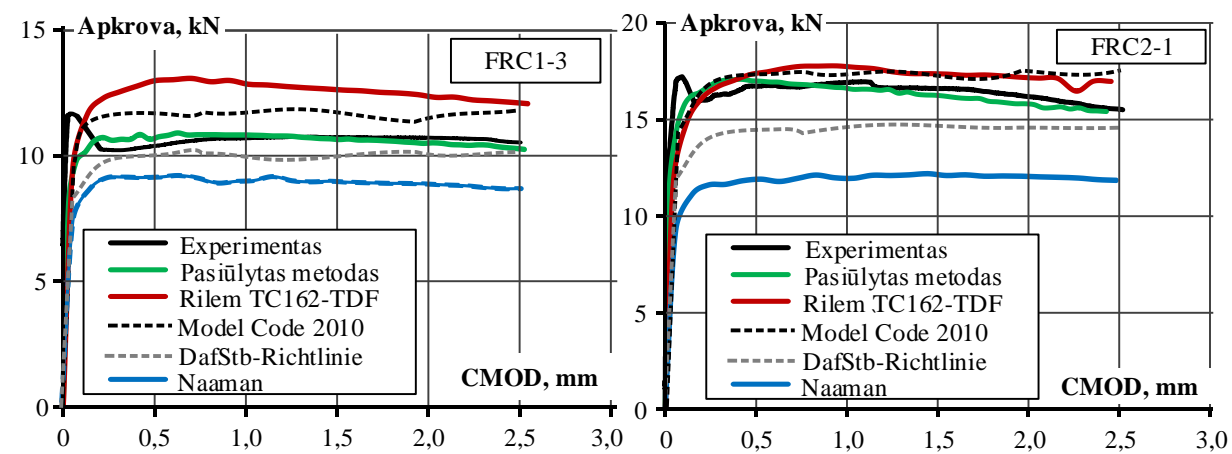

S2.5 pav. Lenkiamujjų elementų (a) FRC1-3 ir (b) FRC2-1 sumodeliuotų apkrovos ir plyšio pločio priklausomybių palyginimas
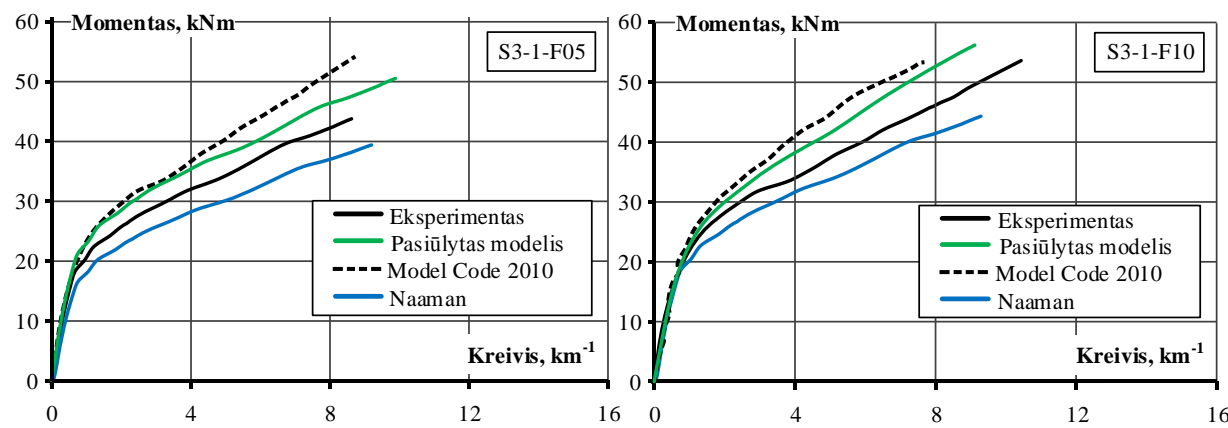

S2.6 pav. Sijų (a) S3-1-F05 ir (b) S3-1-F10 sumodeliuotu momentų ir kreivių priklausomybių palyginimas

\section{Plieno plaušu armuotụ lenkiamụjų gelžbetoninių elementụ pleišèjimo ir deformacijų analizé}

Trečiajame skyriuje atliekama dispersiškai armuotų gelžbetoninių elementų tinkamumo ribinio būvio analizè. Disertacijoje pasiūlytas plieno plaušu ir strypais armuotu gelžbetoninių elementų deformacijų ir pleišèjimo modeliavimo metodas, paremtas įtempių perdavimo (diskretaus pleišèjimo) koncepcija (S3.1 pav.). Skirtingai nuo daugelio tinkamumo ribinio būvio analizès algoritmų, šiuo metodu galima realistiškai modeliuoti konstrukcijos deformacijas, plyšių vystymąsi, įvertinant dispersiškai armuoto betono liekamąji stiprị, strypinès armatūros ir betono sukibimo bei pažeidimo zonos reiškinius.

Autoriaus pasiūlytame metode plieno plaušu armuotas betonas nagrinejjamas kaip vienalytė medžiaga. Deformacijų ir pleišèjimo analizei priimamos pastovios vidutinès liekamojo stiprio reikšmės, nustatytos 2 skyriuje aprašytais metodais. Pasiūlytame algoritme tempiamajai armatūrai gniuždomajam betonui taikoma plokščiųjų pjūvių hipotezè bei laikoma, kad visi plyšiai atsiveria pasiekus pleišèjimo momentą $M_{c r}$. Tempiamojo betono 
deformacijos susideda iš dviejų komponentų: deformacijų dèl tempiamojo sustandèjimo ir liekamojo stiprio. Tempiamojo betono elastiniai įtempiai plyšyje yra nevertinami. Analizė atliekama viename bloke tarp dviejų gretimų plyšių (S3.1 pav.). Vidutinių deformacijų ir atstumų tarp plyšių modeliavimui parenkamas bloko ilgis lygus 1,5 įtempių perdavimo ilgio $l_{t r}$.
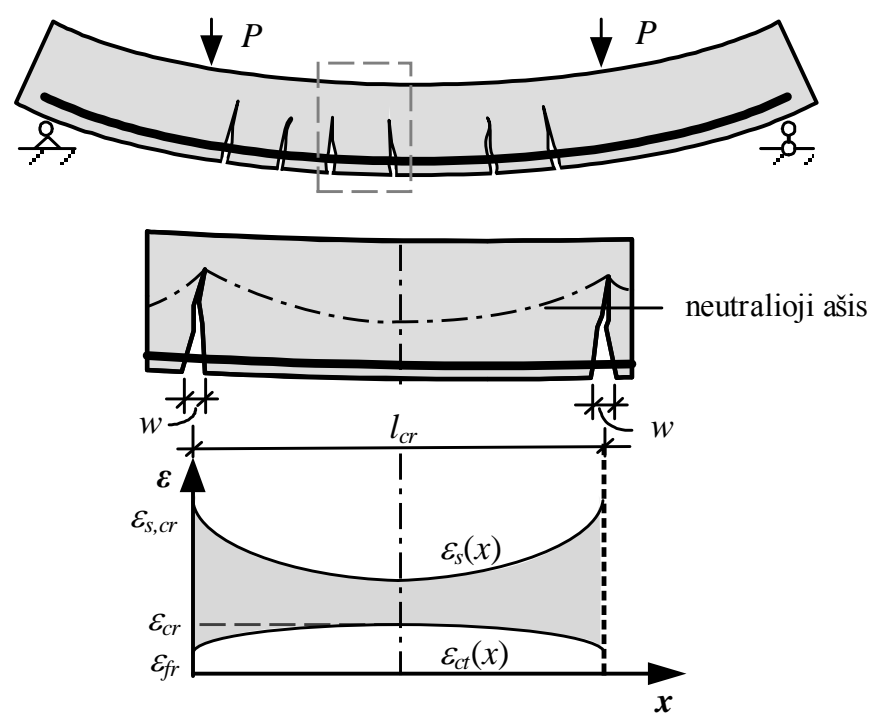

S3.1 pav. Dispersiškai armuoto betono lenkiamųjų elementų modeliavimas

Pasiūlytame algoritme lenkiamojo elemento ịtempių ir deformacijų pasiskirstymas betone ir armatūroje analizuojamas ịvertinant pažeidimo zonas, atsirandančias lenkiamojo dispersiškai armuoto gelžbetoninio elemento kraštuose. Bloke tarp plyšių, įtempiai armatūroje pasiskirsto pagal du dèsnius - elemento galuose pagal priimtą pažeidimo zonos dèsnị, kitose elemento dalyse pagal priimtą betono ir armatūros sukibimo ir slinkties modeli (S3.2 pav.).
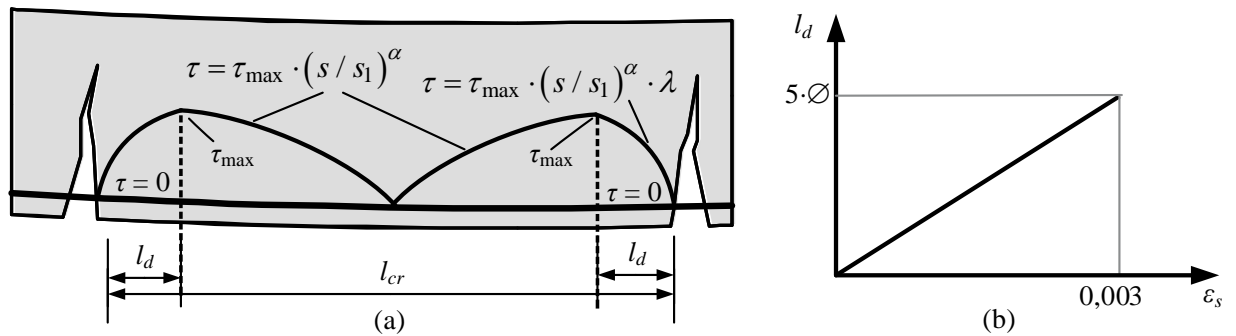

(b)

S3.2 pav. Pažeidimo zonos analizè: (a) netiesinè sukibimo įtempių priklausomybė pažeidimo zonoje ir (b) pažeidimo zonos ilgio modelis 
Taikant Model Code 2010 (fib 2013) pasiūlytą sukibimo modeli, pažeidimo zonos ilgis priimamas lygus $l_{d}=5 \varnothing(\varnothing-$ armatūros strypo skersmuo). Atsižvelgiant ị Kaklausko (2017) ir Juknio (2017) atliktus tyrimus, priimama kad pažeidimo zonos ilgis taip pat tiesiogiai priklauso nuo armatūros deformacijos plyšyje (S3.2b pav.). Taikant pasiūlytaji algoritmą, atliekami dispersiškai armuoto betono ir armatūros deformacijų skaičiavimai, nustatomas elemento kreivis bei vidutiniai atstumai tarp plyšių.

Eksperimentinių tyrimų metu trumpalaike apkrova išbandyta 11 realaus dydžio skirtingu plieno plaušo ir strypinès armatūros kiekiu armuotų gelžbetoninių elementų. Sijos buvo armuotos skirtingu strypinès armatūros armavimo koeficientu $0,3,0,6,1,0 \%$, bei skirtingu plieno plaušo kiekiu, nuo 0,3 iki $1,5 \%$. Eksperimentams naudotų siju pagrindinès charakteristikos pateiktos S3.1 lentelèje ir S3.3 paveiksle. 2 serijos ir 3 serijos siju eksperimentinès momentų ir kreivių diagramos, gautos naudojant bandymų metu išmatuotų deformacijų reikšmes, pateiktos S3.4 paveiksle.

S3.1 lentelė. Eksperimentinių sijų pagrindinès charakteristikos

\begin{tabular}{|c|c|c|c|c|c|c|c|c|c|c|}
\hline \multirow{2}{*}{\multicolumn{2}{|c|}{ Sija }} & $A_{s 1}$ & $A_{s 2}$ & \multirow{2}{*}{$\begin{array}{c}a_{s 2} \\
\mathbf{m m}\end{array}$} & $p$ & $V_{f b}$ & $f_{c}$ & $f_{s}$ & $E_{c}$ & $\boldsymbol{E}_{s}$ \\
\hline & & \multicolumn{2}{|c|}{$\mathrm{mm}^{2}$} & & \multicolumn{2}{|c|}{$\%$} & \multicolumn{4}{|c|}{ MPa } \\
\hline \multirow{4}{*}{$\begin{array}{l}: \frac{\pi}{\vec{D}} \\
\text { 总 } \\
-\end{array}$} & $\mathrm{S} 1-3$ & 755 & 57 & 23 & 1,0 & 0,0 & 48,13 & 632,3 & 36806 & 210505 \\
\hline & S1-F05 & 798 & 56 & 21 & 1,0 & 0,5 & 55,62 & 558,7 & 38342 & 205304 \\
\hline & S1-F10 & 798 & 56 & 20 & 1,0 & 1,0 & 47,95 & 558,7 & 36733 & 205304 \\
\hline & S1-F15 & 798 & 56 & 21 & 1,0 & 1,5 & 52,15 & 558,7 & 37735 & 205304 \\
\hline \multirow{4}{*}{$\begin{array}{l}: \frac{\pi}{\vec{D}} \\
\infty \\
\sim \\
\sim\end{array}$} & $\mathrm{S} 2-3$ & 466 & 57 & 29 & 0,6 & 0,0 & 48,20 & 582,4 & 36791 & 207256 \\
\hline & S2-F05 & 477 & 56 & 25 & 0,6 & 0,5 & 55,62 & 563,6 & 38342 & 213384 \\
\hline & S2-F10 & 477 & 56 & 22 & 0,6 & 1,0 & 47,95 & 563,6 & 36733 & 213384 \\
\hline & S2-F15 & 477 & 56 & 23 & 0,6 & 1,5 & 52,15 & 563,6 & 37735 & 213384 \\
\hline \multirow{3}{*}{ 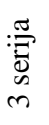 } & B-1-F0 & 226 & 56 & 23 & 0,3 & 0,0 & 64,47 & 800,0 & 40180 & 194155 \\
\hline & B-2-F03 & 226 & 56 & 23 & 0,3 & 0,3 & 65,30 & 800,0 & 40346 & 194155 \\
\hline & B-3-F06 & 226 & 56 & 23 & 0,3 & 0,6 & 62,27 & 800,0 & 39767 & 194155 \\
\hline
\end{tabular}

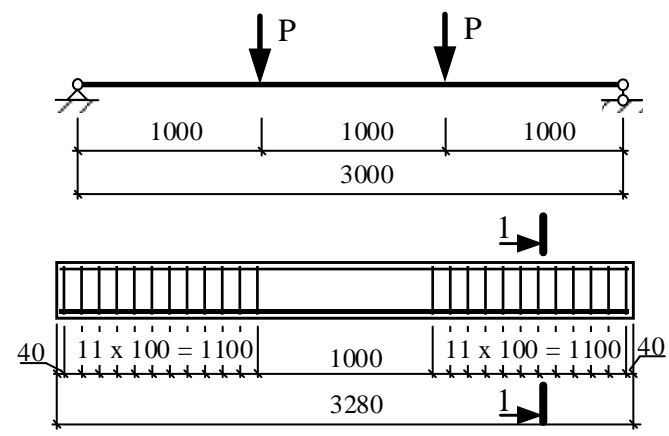

(a)

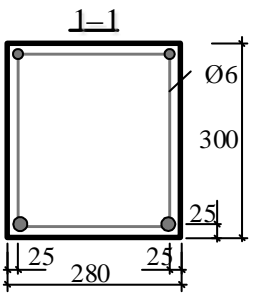

(b)

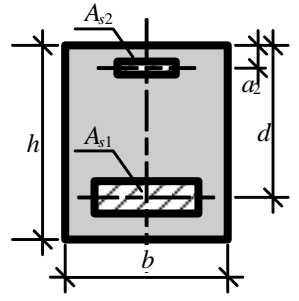

(c)

S3.3 pav. Eksperimentinių sijų (a) apkrovimo, (b) armavimo ir (c) skerspjūvio schemos 
Kaip matyti iš S3.4, S3.5 ir S3.6 paveikslų, eksperimentinių sijų standumas bei pleišejjimas, esant vienodam armatūros strypų armavimo koeficientui, priklauso nuo dispersinio armavimo kiekio.
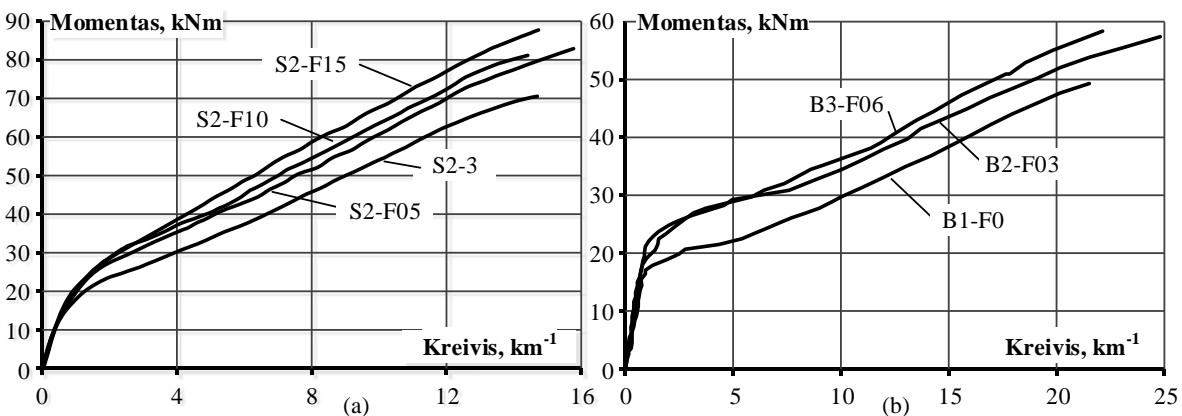

S3.4 pav. Eksperimentinès momentų ir kreivių diagramos: (a) 2 serijos sijų ir (b) 3 serijos sijų

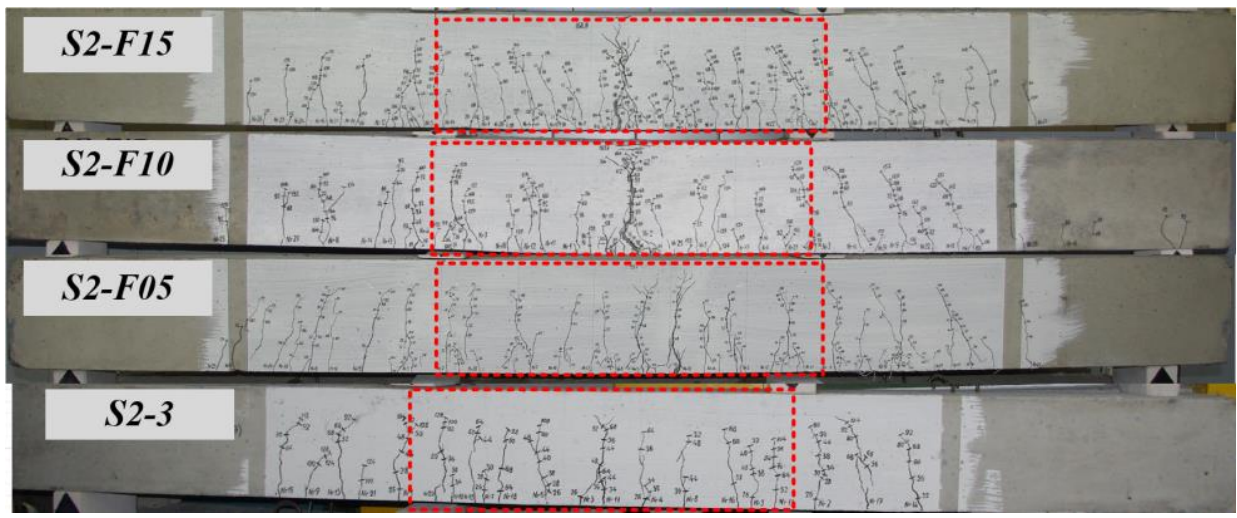

S3.5 pav. Eksperimentinių 2 serijos sijų pleišèjimo schemos

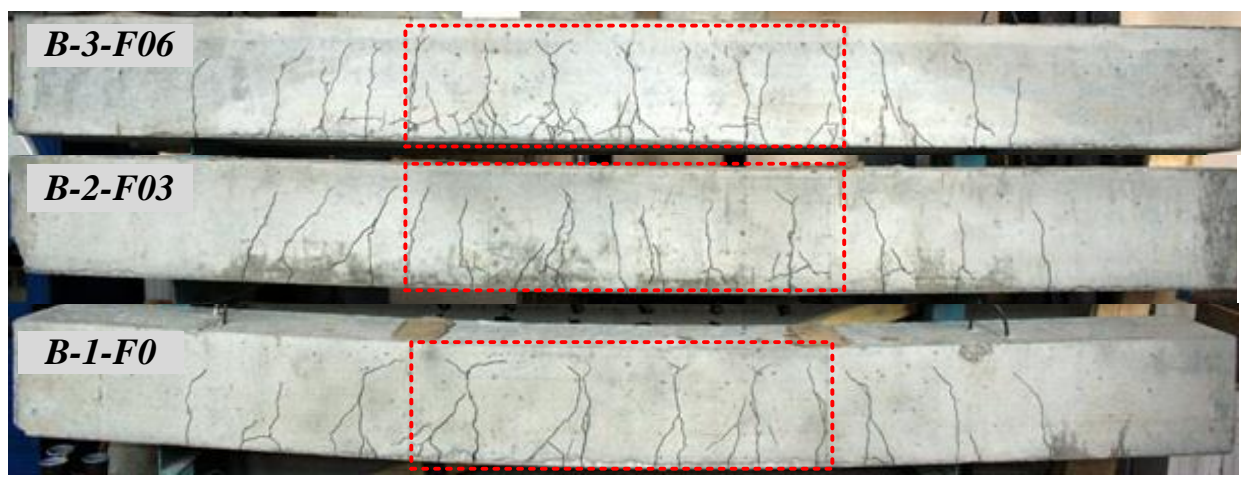

S3.6 pav. Eksperimentinių 3 serijos sijų pleišèjimo schemos 
Gelžbetoninio elemento tūryje esantis plieno plaušas varžo atsiveriančius plyšius ir leidžia perduoti įtempius plyšio plokštumoje. Tai lemia mažesni armatūros ir betono įtempių perdavimo ilgị ir atstumą tarp plyšių. Armuojant didesniu plieno plaušo kiekiu, stebimi mažesni plyšių pločiai bei gaunama standesnè elementų elgsena (S3.5 ir S3.6 pav.).

Plieno plaušu ir strypais armuotų gelžbetoninių elementų deformacijų ir pleišejjimo analizei autoriaus pasiūlytu metodu, pasirinktos tempiamojo dispersiškai armuoto betono liekamojo stiprio medžiagų diagramos nustatytos dviem metodais. Taikant Model Code 2010 projektavimo normose siūlomą modelị, lenkiamujų elementų kreivių reikšmių paklaida, veikiant eksploatacinei apkrovai, siekia maksimaliai $41 \%$ (vidutinè reikšmė $18 \%$, variacijos koeficientas $19 \%$ ). Apskaičiuoto atstumo tarp plyšių maksimali paklaida (S3.2 lentelè) siekia $42 \%$ (vidutinè reikšmè $15 \%$, variacijos koeficientas $20 \%$ ).

S3.2 lentelè. Eksperimentinių ir apskaičiuotų atstumų tarp plyšių palyginimas

\begin{tabular}{|c|c|c|c|c|c|}
\hline \multirow[t]{2}{*}{ Sija } & $l_{c r, \exp }$ & $\begin{array}{c}l_{c r, c a l c} \\
\text { (Naaman) }\end{array}$ & $\begin{array}{c}l_{c r, \text { calc }} \\
(\mathrm{MC} \mathrm{2010)}\end{array}$ & \multirow{2}{*}{$\begin{array}{c}\text { Santykis } \\
l_{c r, \text { calc,Naaman } /} \\
l_{c r, \exp }\end{array}$} & \multirow{2}{*}{$\begin{array}{c}\text { Santykis } \\
l_{c r, c a l c, M C ~ 2010} \\
/ l_{c r, \exp }\end{array}$} \\
\hline & \multicolumn{3}{|c|}{$\mathrm{cm}$} & & \\
\hline S1-3 & 10,00 & \multicolumn{2}{|c|}{$9,59\left(V_{f b}=0\right)$} & \multicolumn{2}{|c|}{0,96} \\
\hline $\mathrm{S} 2-3$ & 10,00 & \multicolumn{2}{|c|}{$10,02\left(V_{f b}=0\right)$} & \multicolumn{2}{|c|}{1,00} \\
\hline B-1-F0 & 22,50 & \multicolumn{2}{|c|}{$20,73\left(V_{f b}=0\right)$} & \multicolumn{2}{|c|}{0,92} \\
\hline S1-F05 & 9,09 & 8,73 & 6,66 & 0,96 & 0,73 \\
\hline S1-F10 & 8,33 & 7,65 & 6,17 & 0,92 & 0,74 \\
\hline S1-F15 & 7,14 & 6,71 & 5,87 & 0,94 & 0,82 \\
\hline S2-F05 & 10,00 & 9,41 & 8,34 & 0,94 & 0,83 \\
\hline S2-F10 & 11,11 & 8,96 & 6,42 & 0,81 & 0,58 \\
\hline S2-F15 & 8,33 & 7,20 & 6,20 & 0,86 & 0,74 \\
\hline B-2-F03 & 15,00 & 17,81 & 16,89 & 1,13 & 1,17 \\
\hline B-3-F06 & 14,29 & 17,12 & 16,34 & 1,14 & 0,83 \\
\hline & & & Vidurkis: & 0,98 & 0,85 \\
\hline & & Variacijc & koeficientas: & 0,12 & 0,20 \\
\hline
\end{tabular}
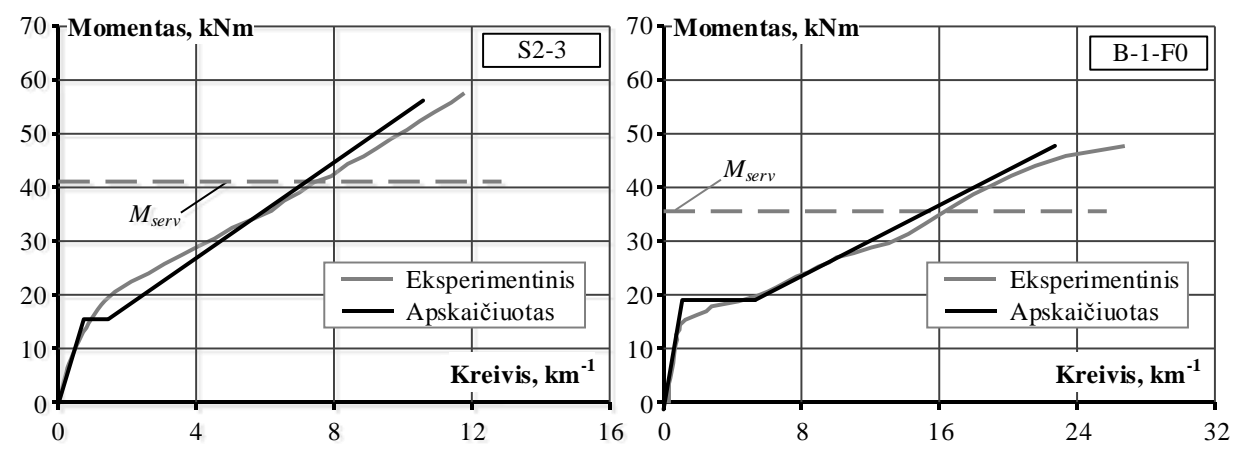

S3.7 pav. Gelžbetoninių sijų be plieno plaušo sumodeliuotų ir eksperimentinių momentų ir kreivių diagramų palyginimas 

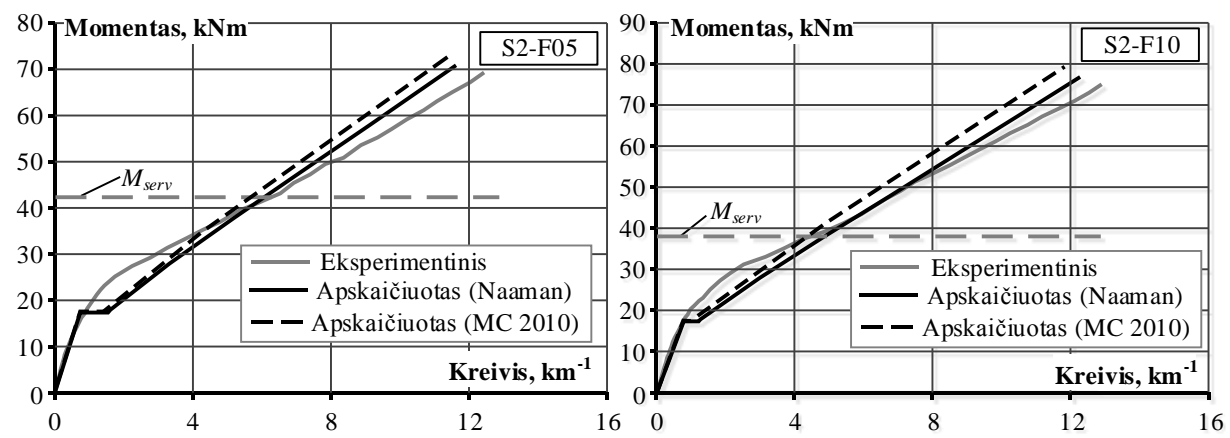

S3.8 pav. 2 serijos sijų sumodeliuotų ir eksperimentinių momentų ir kreivių diagramų palyginimas
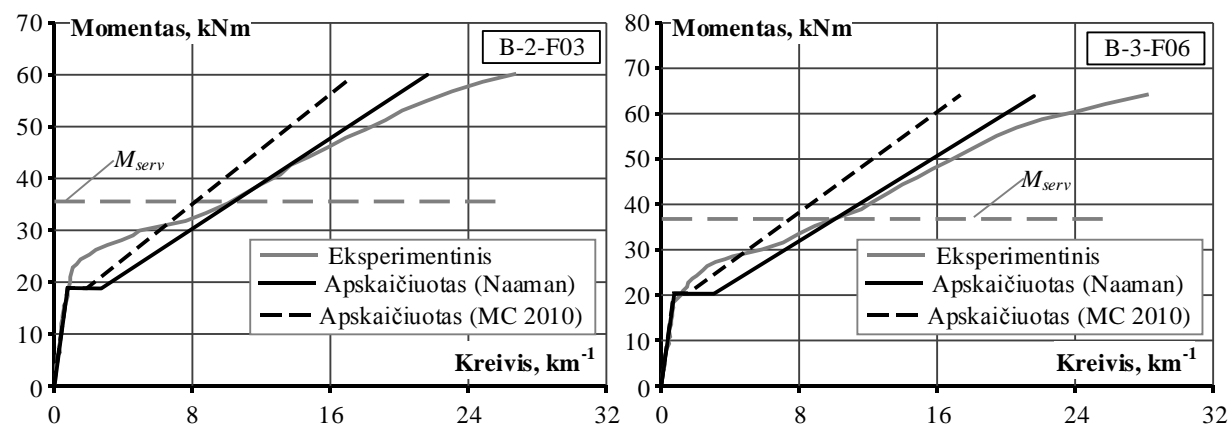

S3.9 pav. 3 serijos sijų sumodeliuotų ir eksperimentinių momentų ir kreivių diagramų palyginimas

Taikant liekamojo stiprio reikšmes, apskaičiuotas pagal Naaman metodą, autoriaus pasiūlytu ịtempių perdavimo algoritmu sumodeliuota deformacijų ir pleišèjimo elgsena atitinka eksperimentinius rezultatus. Modeliuotų plieno plaušu armuotų sijų su strypine armatūra elementų kreivių paklaida siekia $10 \%$ (vidutinė reikšmė siekia $7 \%$, variacijos koeficientas - $9 \%$ ). Vidutinių atstumų tarp plyšių paklaida neviršija $14 \%$ (vidutinè reikšmè ir variacijos koeficientas siekia atitinkamai 2 ir $12 \%$ ).

\section{Bendrosios išvados}

Apibendrinus atliktų tyrimų rezultatus galima teigti, kad:

1. Pasiūlytas tempiamojo plieno plaušu armuoto betono liekamojo stiprio nustatymo metodas, paremtas atvirkštinio uždavinio sprendimo algoritmu, gali būti taikomas kaip alternatyva projektavimo normose ir rekomendacijose pateiktiems medžiagų modeliavimo metodams. Priešingai nei tradiciniai metodai, kurie taiko empirines išraiškas ir yra susieti su tik tam tikros geometrijos eksperimentinių 
elementų duomenimis, pasiūlytas metodas yra paremtas bendraisiais medžiagų mechanikos principais. Šis metodas gali būti universaliai taikomas ịvairios geometrijos elementų analizei bei leidžia nustatyti liekamajị stiprị bet kuriame apkrovos lygyje.

2. Skirtingai nuo daugelio armuoto betono eksploatacinių savybių analizès metodų, kuriais atskirai atliekama deformacijų ar pleišejimo analizè, algoritmas, pagrịstas itempių perdavimo principu, leidžia vienu metu modeliuoti strypais ir plieno plaušu armuoto betono deformacijas ir pleišejjimą. Liekamojo stiprio, armatūros ir betono sukibimo ir slinkties bei pažeidimo zonos modeliai yra esminiai parametrai, lemiantys armuoto betono eksploatacinių savybių analizès rezultatus.

3. Autoriaus pasiūlytas metodas, pagrịstas įtempių perdavimo principu ir pažeidimo zonos koncepcija, užtikrina adekvačią gelžbetoninių sijų be plieno plaušu tinkamumo ribinio būvio analizę. Gautos eksperimentinius rezultatus atitinkančios vidutinių deformacijų ir atstumo tarp plyšių reikšmès (paklaida atitinkamai siekia 5 ir $7 \%$ ).

4. Standartiniai liekamojo stiprio nustatymo metodai yra tinkami plieno plaušu armuoto betono konstrukcijų be strypinès armatūros tinkamumo ribinio būvio analizei, tačiau nepakankamai tiksliai vertina lenkiamųjų strypais ir plieno plaušu armuotų elementų elgseną. Taikant Model Code 2010 metodu nustatytas liekamojo stiprio reikšmes, dispersiškai armuotų gelžbetoninių sijų vidutinis kreivis ir atstumas tarp plyšių ịvertinami nepakankamai - apskaičiuojamos vidutiniškai $18 \%$ (maksimali reikšmè $41 \%$ ) ir $15 \%$ (maksimali reikšmè $42 \%$ ) mažesnès reikšmès.

5. Sumodeliuoti deformacijų ir atstumo tarp plyšių rezultatai, gauti naudojant Naaman pasiūlytą empirinị liekamojo stiprio nustatymo metodą, atitinka eksperimentinius dispersiškai armuotų gelžbetoninių sijų rezultatus. Nagrinėtų elementų kreivio ir atstumo tarp plyšių vidutinès paklaidos atitinkamai siekia 7 \% (maksimali reikšme $10 \%$ ) ir $2 \%$ (maksimali reikšmé $14 \%$ ). 


\section{Annexes ${ }^{1}$}

Annex A. Declaration of Academic Integrity

Annex B. The Co-authors' Agreements to Present Publications for the Dissertation Defence

Annex C. Copies of Scientific Publications by the Author on the Topic of the Dissertation 


\section{Adas MEŠKĖNAS}

\section{SERVICEABILITY ANALYSIS OF STEEL FIBRE}

REINFORCED CONCRETE BEAMS

\section{Doctoral Dissertation}

Technological Sciences,

Civil Engineering (02T)

\section{Adas MEŠKĖNAS}

\section{PLIENO PLAUŠU ARMUOTŲ GELŽBETONINIỤ SIJŲ TINKAMUMO RIBINIO BŪVIO ANALIZE் \\ Daktaro disertacija}

Technologijos mokslai, statybos inžinerija (02T)

201801 26. 11,5 sp. I. Tiražas 20 egz.

Vilniaus Gedimino technikos universiteto

leidykla „Technika“,

Saulètekio al. 11, 10223 Vilnius,

http://leidykla.vgtu.It

Spausdino Bl UAB „Baltijos kopija“

Kareivių g. 13B, 09109 Vilnius 